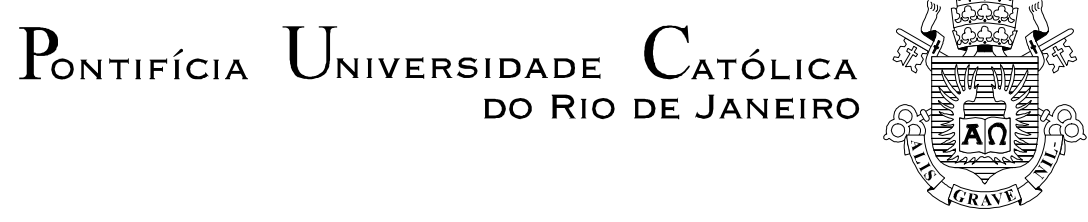

Alessa Patrícia Dias da Silva

\title{
O IMAGINÁRIO DA LAPA: APOGEU, DECADÊNCIA E RECONSTRUÇÃO
}

Dissertação de Mestrado

Dissertação apresentada ao Programa de Pós-graduação em Literatura, Cultura e Contemporaneidade da PUC-Rio como requisito parcial para obtenção do grau de Mestre.

Orientador: Prof. Renato Cordeiro Gomes

Rio de Janeiro

Abril de 2014 


$$
\text { Pontifícia } U_{\text {niversidade }} \text { Católica }_{\text {do Rio Janeiro }}
$$

\title{
O IMAGINÁRIO DA LAPA: APOGEU, DECADÊNCIA E RECONSTRUÇÃO
}

\author{
Dissertação apresentada como requisito \\ parcial para obtenção do grau de Mestre pelo \\ Programa de Pós-Graduação em Literatura, \\ Cultura e Contemporaneidade do \\ Departamento de Letras do Centro de \\ Teologia e Ciências Humanas da PUC-Rio. \\ Aprovada pela Comissão Examinadora abaixo \\ assinada.
}

Prof. Renato Cordeiro Gomes Orientador Departamento de Letras - PUC-Rio

Profa. Giovanna Ferreira Dealtry Departamento de Comunicação Social - PUC-Rio

Profa.Aline da Silva Novaes UCAM

Profa. Denise Berruezo Portinari Coordenadora Setorial do Centro de Teologia e Ciências Humanas - PUC-Rio 
Todos os direitos reservados. É proibida a reprodução total ou parcial do trabalho sem autorização da universidade, da autora e do orientador.

\section{Alessa Patrícia Dias da Silva}

Graduou-se em Letras na UERJ-FFP (Universidade do Estado do Rio de Janeiro Faculdade de Formação de Professores) em 2008. Cursou Pós- Graduação em Estudos Literários na mesma universidade em 2009. Atualmente leciona Língua Portuguesa na Secretaria Estadual de Educação.

Ficha Catalográfica

Silva, Alessa Patricia Dias da

O imaginário da Lapa: apogeu, decadência e reconstrução/ Alessa Patricia Dias da Silva ; orientador: Renato Cordeiro Gomes. - 2014.

123 f. : il. (color.) ; $30 \mathrm{~cm}$

Dissertação (mestrado) - Pontifícia Universidade Católica do Rio de Janeiro, Departamento de Letras, 2014.

Inclui bibliografia

1. Letras - Teses. 2. Rio de Janeiro. 3. Lapa. 4. Imaginário. 5. Boemia. 6. Prostituição. 7. Gentrificação. I. Gomes, Renato Cordeiro. II. Pontifícia Universidade Católica do Rio de Janeiro. Departamento de Letras. III. Título. 
Para meu noivo Alexandre e meus familiares pelo apoio e confiança. 


\section{Agradecimentos}

Agradeço primeiramente Deus por ser meu sustentáculo.

Especialmente, ao meu orientador Renato Cordeiro Gomes, pelo carinho e apoio, nos momentos mais difíceis, nas horas mais importantes e delicadas, sempre depositando total confiança em meu trabalho.

À PUC-Rio pelos auxílios concedidos, sem os quais este trabalho não poderia ter sido realizado.

A minha mãe, meu irmão e meus tios, Josemir e Maria, sempre torcendo por minha jornada e me ajudando a superar os percalços que se colocaram em meu caminho.

Ao meu noivo Alexandre pelo cuidado, carinho e compreensão e por estar ao meu lado em todas as etapas deste trabalho.

Aos professores do programa de Mestrado por me guiarem em dois anos de disciplina, especialmente à professora Marília Rothier Cardoso, que me incentivou no início do meu trabalho. 


\section{Resumo}

Silva, Alessa Patrícia Dias; Gomes, Renato Cordeiro (Orientador). Imaginário da Lapa: apogeu, decadência e reconstrução. Rio de Janeiro, 2014. 123p. Dissertação de Mestrado - Departamento de Letras, Pontifícia Universidade Católica do Rio de Janeiro.

Nos últimos anos, o bairro da Lapa tem se configurado como uma área de forte atratividade para o lazer noturno na cidade do Rio de Janeiro. O objetivo dessa dissertação de caráter interdisciplinar é analisar como tem sido feita a retomada do bairro da Lapa, relacionando-a ao imaginário que se construiu sobre o local. Tal recuperação tem sido fortemente apoiada no imaginário construído pela boemia lapiana das décadas de 20 e 30. O imaginário será abordado de duas formas distintas: aquele que se constrói no seio do grupo do boêmio, responsável pela transformação da Lapa em mito, e o imaginário construído social e politicamente, instaurado pelos donos do poder que objetivavam a destruição e moralização da Lapa - tendo como foco de ataque a prostituição no bairro - mas que em um influxo contrário contribuiu para a legitimação do espaço. Serão utilizados como objetos de análise textos produzidos por quem viveu a boemia pelas ruas do bairro, a exemplo: o livro de crônicas, Roteiro da Lapa... e outros roteiros, de Alberto Deodato; Adeus Lapa, de Hernani do Irajá; Noturno da Lapa e Lapa, de Luís Martins e Lábios que beijei, de Aguinaldo Silva.

\section{Palavras-Chaves}

Rio de Janeiro; Lapa; imaginário; boemia; prostituição; gentrificação. 


\section{Abstract}

Silva, Alessa Patrícia Dias; Gomes, Renato Cordeiro (Advisor). The imaginarium of Lapa: apogee, decay and reconstruction. Rio de Janeiro, 2014. 123p. MSc. Dissertation - Departamento de Letras, Pontifícia Universidade Católica do Rio de Janeiro.

During the last years, the neighborhood of Lapa has been changing and becoming a very attractive area as an option for the nightlife in Rio de Janeiro. This cross-curricular essay intends to analyze how the resumption found in Lapa has been taking place, connecting it to the imaginarium built over the area. Such recovery has been strongly supported on the imaginarium set by the bohemian spirit of Lapa in the $20 \mathrm{~s}$ and $30 \mathrm{~s}$. The imaginary will be approached in two different ways: the one built in the bohemian circle's crib, responsible for transforming Lapa into a myth, and the imaginarium built socially and politically, introduced by the owners of the power, who wanted its destruction and moralization - with the prostitution found in the neighborhood as the main striking spot - but responsible for legitimizing the area through an opposite influx movement. There will be used as analysis references texts wrote by people who witnessed the bohemian process through the streets of Lapa, such as the book of Chronicles Roteiro da Lapa... e outros roteiros, wrote by Alberto Deodato; Adeus Lapa, wrote by Hernani do Irajá; Noturno da Lapa and Lapa, wrote by Luís Martins and Lábios que Beijei, wrote Aguinaldo Silva.

\section{Keywords}

Rio de Janeiro; Lapa; Imaginarium; bohemian; prostitution; gentrification 


\section{Sumário}

1. Introdução 11

2. A construção espacial da Lapa: modernidade e surgimento 16 de novos personagens na cena urbana.

2.1. A formação do espaço da Lapa 16

2.2. A Lapa Boêmia 26

2.2.1 $O$ fenômeno da boemia e os boêmios da Lapa $\quad 27$

2.2.2. Eu queria ser francesa: a prostituição na Lapa 39

3. A construção do imaginário da Lapa 46

3.1. A Lapa reconstruída pela memória 52

3.2. A decadência da Lapa 68

4. Eis que ressurge das cinzas! $\quad 79$

4.1. As atuais políticas públicas no bairro da Lapa 88

4.2. A música e a renovação cultural da Lapa 93

5. Considerações Finais 102

$\begin{array}{ll}\text { 6. Referências bibliográficas } & 108\end{array}$

Anexo I 


\section{Lista de figuras}

Figura 1 - Vista da Lagoa do Boqueirão com os Arcos da Lapa. 18

Figuras 2 e 3 - Demolições para a construção da Avenida Central. $\quad 21$

Figura 3 - Vista da Avenida Rio Branco, em $\underline{1909}$.

Figura 4 - Abertura da Avenida Mem de Sá, em 1904.

Figura 5 - Mapa do "cinturão de pobreza" - Rio de Janeiro 25

Figura 6 e 8 - Imagens da Indumentária utilizada na cidade do Rio de Janeiro, na Belle Époque. 40

Figura 09 - Imagem da prostituta Suzanne $\quad 64$

Figuras 10 - 14 - Evolução do espaço urbano da Lapa 76

Figura 15 - Imagens da Rua do Lavradio 85

Figura 16 - Imagens da Feira do Lavradio 86

Figura 17 - Limites do novo bairro da Lapa. 89

Figura 18 - Mapa dos novos limites da Lapa e as opções de 91 consumo, cultura e lazer que o bairro oferece.

Figura 19 - Área de atuação da operação Lapa Presente 92 
Abre a janela formosa mulher

Cantava o poeta trovador

Abre a janela formosa mulher

Da velha Lapa que passou

Vem dos vice-reis

E dos tempos do Brasil imperial

Através de tradições

Até a república atual

Dos grandes mestres do passado

Dedicaram obras de grande valor

A Lapa de hoje e a Lapa de outrora

$Q u e$ revivemos agora

Ah serestas

Quantas saudades nos trás

Dos cabarés e as festas

Emolduradas pelos lampiões a gás

As sociedades e os cordões dos antigos carnavais

Olha a roda de malandro

Quero ver quem vai cair

Capoeira vai plantando

Pois agora vais subir

Poeira, oi poeira

O samba vai levantar poeira poeira, oh! Poeira

O samba vai levantar poeira

Imagem do Rio antigo

Berço de grandes vultos da história A moderna arquitetura lhe renova a toda hora

Mas os famosos arcos, os belos mosteiros

São relíquias deste bairro

Que foi o berço de boêmios seresteiros

Abre a janela formosa mulher

Cantava o poeta trovador

Abre a janela formosa mulher

Da velha Lapa que passou

(Lapa em três tempos, Velha Guarda da Protela) 


\section{1. \\ Introdução}

A Lapa passou por várias transformações no decorrer da história. As mudanças ocorridas na organização do espaço urbano contribuíram para o seu apogeu, decadência e atual reconstrução. A construção do imaginário da Lapa está irremediavelmente associada a sua constituição territorial, seja pela transformação do espaço físico, seja pela posse desse espaço pelos personagens que ocuparam o bairro.

Esse espaço urbano foi modificado inúmeras vezes, e tais modificações ora contribuíram para formação e legitimação do território boêmio, ora, para sua decadência. A tentativa de destruição da Lapa é o que em influxo contrário vai legitimar seu imaginário. É na decadência que os boêmios procuram revitalizar a memória de paraíso perdido. A Lapa morrendo, começou a viver ávida secreta dos símbolos poéticos, multiplicando-se em muitas Lapas.

Em fins do século XIX e início do século XX, a modificação do território proporcionou novos tipos de lazer e sociabilidade no bairro A Lapa noturna começou a despontar e a receber uma gama variada de personalidades, tornandose centro da boemia intelectual carioca. Já em meados do século $\mathrm{XX}$, as transformações ocorridas na cidade, em parte responsáveis pela decadência do bairro, destruíram parte da Lapa que, já abalada por outras estruturas, começou a ruir. Em fins do século XX, a Lapa passou por novas modificações no espaço urbano, no entanto essas tinham por objetivo a recuperação do bairro e de seu imaginário criado e legitimado nos períodos anteriores.

Hoje, esse espaço boêmio tem movimentado o comércio e sido alvo de revitalização do bairro, realizada tanto por meio de iniciativas públicas, quanto de privadas. Pretende-se lucrar com essa Lapa. Com as intervenções no espaço urbano, busca-se restaurar essa imagem de paraíso perdido construído por meio dos discursos boêmios produzidos quando a Lapa já entrava em seu período de decadência. 
A revitalização da Lapa é fortemente apoiada no imaginário que se construiu sobre o local nas décadas de 20 e 30, nas quais a Lapa consolida-se como berço da boemia intelectual carioca.

O imaginário lapiano será abordado aqui levando em consideração duas formas de construção: uma que se dá no nível das experiências pessoais, individualmente ou no seio de subgrupos sendo uma imagem subjetiva acerca do objeto observado e outra construída na realidade social. Este é construído social e politicamente, instaurado pelos donos do poder que objetivavam a destruição e moralização da Lapa, classificando-a como um antro de perversão devendo, portanto, ser destruída; e aquele se dá no seio do grupo do boêmio, responsável pela transformação da Lapa em mito.

Para compreendermos melhor a produção do imaginário lapiano faz-se necessário entender o processo de urbanização da Lapa, como o bairro tornou-se esse espaço ocupado por boemia, malandragem e prostituição e que elementos históricos e geográficos tornaram possível a construção de um território tão profícuo ao aparecimento dessas identidades

A escolha metodológica está embasada em uma abordagem dialógica entre textos teóricos e literários, minha pesquisa foi essencialmente bibliográfica, não houve uma pesquisa antropológica, não estive na Lapa para observá-la. O que teremos aqui é uma análise dos textos produzidos sobre o local.

O critério de seleção dos textos literários escolhidos foi elencar e analisar memórias de quem vivera a boemia pelas ruas do bairro. Foram utilizados como objetos de análise: o livro de crônicas Roteiro da Lapa... e outros roteiros e Adeus Lapa, pertencentes, respectivamente a Hernani do Irajá, e Alberto Deodato, boêmios da década de 20; Noturno da Lapa e Lapa, de Luís Martins, e textos, pertencentes a outros boêmios da geração de 30, retirados das antologias sobre a Lapa, organizadas pela Isabel Lustosa, Lapa do desterro e do desvario - uma antologia; e pelo Gasparino Damata, Antologia da Lapa. Segundo Velasquez (1994:26):

apesar da distância entre as gerações (...) este conjunto de memorialistas elege coincidentemente as décadas de 20,30 e 40, como tempo que marcaram, respectivamente, a construção, o auge e a desagregação do espaço boêmio da Lapa. Para caracterizar a história da Lapa no primeiro século recortam-na assim em três diferentes momentos. (Grifo meu) 
Ainda que afirmado por Velasquez, não há nenhum tipo de coincidência na eleição, feita pelos memorialistas, das décadas de 20, 30 e 40. A década de 20 foi o período de surgimento da boemia intelectual no bairro (se o Rio de Janeiro vivia a Belle Époque, Montmartre era a Lapa!). Na década de 30, a Lapa encontrava-se em seu período áureo e a boemia consolidava-se no local. Já a década de 40 marcou o início da decadência do bairro. Se tais décadas marcaram os principais momentos da história lapiana e boêmia, é extremamente aceitável que um grande número de escritos sobre a Lapa se refira a esse período.

A investigação realizada sobre a Lapa não se apóia em um único conceito, mas em uma análise de diferentes vetores que compõe este território. Desta forma, a pesquisa foi construída com um caráter interdisciplinar, levando em consideração aspectos geográficos, sociais e econômicos, bem como literários, atrelados aos textos memorialísticos analisados.

No entanto, não há a pretensão de realizar um trabalho sobre a história da Lapa, o que há aqui é um recorte, analisaremos alguns aspectos do bairro. Por exemplo, a malandragem, tão presente e característica da Lapa, não figura nesta dissertação e o leitor não vai esbarrar com Madame Satã pelas páginas a seguir. Este trabalho tem por objetivo analisar a revitalização do bairro da Lapa que se encontra apoiada nesse imaginário construído em parte pelas narrativas boêmias. Pensaremos como esse imaginário se formou e de que maneira ele vem sendo restaurado. Os capítulos da dissertação estão dispostos da seguinte maneira.

No primeiro capítulo, é traçado um panorama da construção espacial da Lapa, desde a sua fundação até as reformas empreendidas no Rio de Janeiro, durante a administração Pereira Passos. Importante ressaltar que, apesar de realizar uma descrição das reformas ocorridas na cidade, esse trabalho não pretende analisar profundamente tal período. Sendo assim, as descrições podem parecer um tanto quanto superficiais e apressadas, mas elas aparecem como pano de fundo para explicar a ocupação do território lapiano, decorrentes das mudanças no centro da cidade.

Nesse capítulo, falamos da construção da noção de modernidade na cidade do Rio de Janeiro, visto que é essa tal modernidade, que vai proporcionar novos tipos de lazer, sociabilidade e prazer na cidade e são apoiadas nela que ocorrem as 
remodelações do espaço. Os novos usos da cidade contribuem para o aparecimento das figuras do boêmio e da prostituta. E é por meio dessa figuras que analisamos a construção do imaginário da Lapa. Ainda neste capítulo, é realizada uma breve descrição do grupo boêmio e da prostituição de luxo, que se instalaram no bairro.

O segundo capítulo versa sobre a formação do imaginário da Lapa. Para tal, discute-se o conceito de imaginário e como o imaginário, especificamente do bairro da Lapa, foi construído por meio de discursos memorialísticos produzidos pela boemia. São analisadas as narrativas produzidas pelos boêmios e a construção do imaginário pelo viés da memória, uma vez que, quando estes textos foram escritos, a Lapa já entrara no seu período de decadência e os boêmios já haviam deixado a boemia.

O terceiro, e último capitulo, fecha o ciclo apogeu, decadência, reconstrução. Nele são descritas as atuais políticas de revitalização do bairro e a tentativa pós-moderna de transformar a Lapa em espaço que recupera uma tradição e uma identidade profundamente carioca.

Ainda que façamos uma análise dos três períodos que compõem a Lapa, sendo necessário muitas vezes deslocar-nos para o passado por meio das narrativas, a visão sobre a Lapa está ancorada no presente. É o que a Lapa é hoje que nos movimenta a olhar o que ela foi. Se ela está sendo retomada, reconstruída, revitalizada, recuperada, e tantos outros "re", nos inquieta saber o que ela foi e o que apóia e ancora em que ela está se tornando.

A apreciação pela temática vem desde a pós-graduação em Letras, na UERJ (Universidade Estadual do Rio de Janeiro). Nesse período estudei a boemia literária da rua Ouvidor, e em diversos textos, os boêmios decretavam a morte da boemia, mas eu me questionava: e a boemia da Lapa?

Ingressei no mestrado com um projeto que pretendia realizar reflexões acerca do fenômeno da boemia no Rio de Janeiro, desde a Geração boêmia de 1889 até a boemia da Lapa nos 20, analisando quais mudanças a figura do boêmio sofreu no decorrer dos anos e de que maneira a remodelação do espaço urbano interferiu na configuração deste grupo deslocando-o dos cafés da Ouvidor para a Lapa.

No entanto, após algumas conversas com meu orientador, cheguei à conclusão de que aquela boemia da Ouvidor morrera sim, e que na Lapa 
despontava um novo tipo de boêmio. Decidi dedicar-me exclusivamente à boemia da Lapa e descobri que a "história" da Lapa, seu período de apogeu e o imaginário construído sobre o local estavam estritamente ligados à figura da boemia intelectual que ancorou no bairro. E que era apoiada nesse imaginário que ocorria a retomada do bairro.

Acredito por fim que com este trabalho poderemos contribuir para os estudos culturais e interdisciplinares. É de extrema importância estudar os fenômenos culturais, inserindo-se o grupo boêmio nessa gama de significações possíveis de análise, para a compreensão dos fenômenos sociais e culturais ocorridos no Rio de Janeiro, especificamente na Lapa, uma vez que, segundo Heidrun Olinto (1993), o mundo em que vivemos é uma construção conceitual como resultado de experiências produzidas por interações paralelas em esferas socioculturais consensuais que traduzem experiências, necessidades e interesses biológicos e sociais comuns internalizados no decorrer da história de socialização dos indivíduos. 


\title{
2. \\ A CONSTRUÇÃO ESPACIAL DA LAPA: MODERNIDADE E SURGIMENTO DE NOVOS PERSONAGENS NA CENA URBANA.
}

\author{
Assim também, exatamente, é a Lapa: uma praça, uma rua - a rua e o \\ largo da Lapa; e em torno a Lapa, propriamente dita, certamente um \\ dos recantos mais estranhos, sugestivos e pitorescos da cidade do Rio \\ de Janeiro. ${ }^{1}$
}

Eis a Lapa. Ornada por um dos mais enigmáticos cartões postais da cidade, o Aqueduto da Carioca estria a praça recriando ao seu modo $o$ encontro entre o antigo e o novo, com soberania e exatidão. Fonte transbordante de lirismo e poesia, poder-se-ia dizer que a Lapa é o mito fundador do espírito da Cidade Maravilhosa. ${ }^{2}$

2.1.

A formação do espaço da Lapa

Para compreendermos melhor a produção do imaginário lapiano faz-se necessário entender o processo de urbanização da Lapa. Outro ponto importante, no que diz respeito à formação desse imaginário, é a construção dos símbolos que materializam a Lapa no espaço urbano: os Arcos da Lapa e a Igreja de Nossa Senhora do Carmo da Lapa do Desterro. Sendo assim, também pontuaremos o aparecimento dessas construções na região.

\footnotetext{
${ }^{1}$ MARTINS, Luís. Noturno da Lapa. 2a Ed. São Paulo: Vertente, 1979: 63

${ }^{2}$ Plano de marketing do Pólo Novo Rio Antigo, 2006-2007: 22
} 
A Igreja, que segundo Damata (2007), confere a Lapa origens nobres e puras, teve sua construção iniciada em 1751, pelo padre Ângelo Siqueira Ribeiro Prado, que levantou um seminário e uma capela em louvor a Nossa Senhora da Lapa do Desterro. A capela foi transformada em Igreja em 1810, por frades carmelitas que a receberam por moradia após terem que desocupar o convento no Largo do Carmo, atual Praça XV, para moradia do Monarca D. João VI. É importante destacar que a data de fundação da Igreja é considerada a data de fundação do bairro.

O Aqueduto da Carioca é considerado a obra arquitetônica de maior importância do Rio Antigo e um dos principais símbolos da cidade. Imponente, possui 42 arcos, 17, 8 metros de altura e 270 metros de extensão. Foi construído em 1723 e tinha como objetivo resolver o problema da falta de água na cidade, conduzindo a água do Rio Carioca da altura do Morro do Desterro, atual bairro de Santa Teresa, para o Morro de Santo Antônio. Os Arcos da Lapa, como o aqueduto ficou conhecido, se confunde não somente com a história da Lapa, como também funciona como um dos cartões postais da cidade. No século XIX, o aqueduto foi desativado e a partir de 1896, "numa operação urbanística tão insólita quanto bem sucedida" (DUARTE, 2009:3), passou a ser utilizado como viaduto de acesso dos bondes elétricos que ligam o bairro de Santa Teresa ao centro da cidade.

A despeito da proximidade com relação ao centro tradicional da cidade, até finais do século XVIII, a Lapa encontrava-se bastante rarefeita, tal fenômeno, para Duarte (2009), pode ser creditado à proximidade da Lagoa do Boqueirão (Figura 1), insalubre, visto que ali eram jogados os dejetos da população, e o fato de a região se encontrar cercada pelos morros do Desterro (atual bairro de Santa Teresa), Santo Antonio e Senado, dificultando a sua ocupação. 


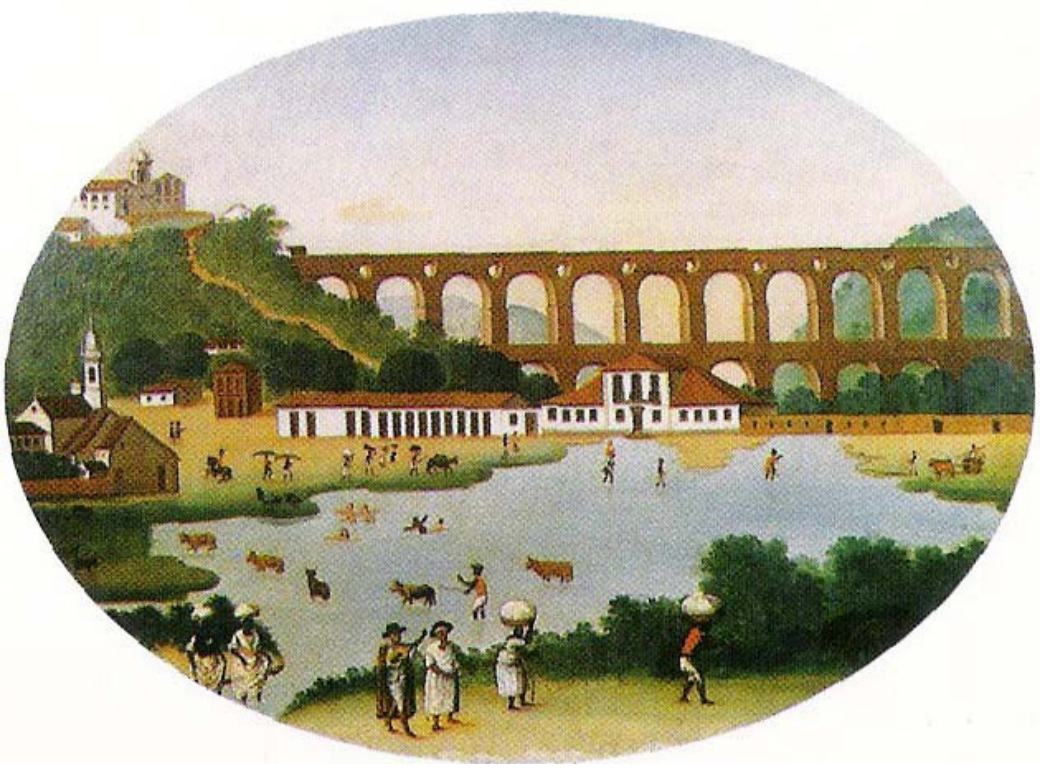

Figura 7 - Vista da Lagoa do Boqueirão com os Arcos da Lapa - Tela atribuída a Leandro Joaquim. Museu Histórico Nacional - Num primeiro plano desta paisagem, vemos a Lagoa do Desterro e a Igreja de N ${ }^{a}$. Sr. ${ }^{a}$ Senhora do Carmo do Desterro da Lapa; em segundo plano o Morro do Desterro (à esquerda), os aquedutos da Lapa e o Morro de Santo Antônio (à direita); e o Morro do Senado (em terceiro plano, por trás dos arcos da Lapa).

Com a vinda da Família Real Portuguesa para o Brasil, o Rio de Janeiro tornou-se sede da corte metropolitana, fato este que proporcionou uma mudança significativa na organização do espaço urbano e na organização econômicopolítico-cultural brasileira. Dom João VI foi o primeiro modernizador da cidade que se erguia. O novo domicílio real deveria estar à altura de seus novos moradores. Juntamente com a família Real, instalou-se a primeira modernização do espaço fluminense. O processo de povoamento da Lapa data desse período, diversos casarões foram construídos para abrigar a Corte Portuguesa, que chegou ao Rio de Janeiro juntamente à Família Real.

Mesmo após as "reformas" empreendidas pela Corte Imperial, o Rio de Janeiro permanecia caótico e insalubre. A cidade era reduto da maior quantidade de africanos no continente, ao mesmo tempo em que adotava padrões europeus de comportamento e consumo. A feição multicultural da cidade contribuía para a complexidade das relações ali vigentes. 
O imaginário brasileiro ia se modificando, os hábitos europeus eram incorporados aos hábitos brasileiros. "Uma enxurrada de serviços alienígenas popularizava por aqui os costumes e o gosto europeus. (...) Tudo o que fora herdado do elemento índio, negro ou asiático era substituído pelo equivalente europeu." (OLIVEIRA, F., 2008:21)

Com a nova iluminação a gás, obra iniciada por Barão de Mauá em 1849 e concluída em 1854, abre-se a possibilidade de uma vida noturna, ou seja tem-se uma mudança na vivência da rua. As atividades na cidade, anteriores a essa iluminação, eram realizadas predominantemente durante o dia, para que houvesse o aproveitamento da luz solar. A iluminação artificial das ruas possibilita o aparecimento de diferentes atividades.

No que se refere à iluminação pública, esta passou a ser um dos grandes símbolos da modernidade para o país, sua implantação se deu a partir de diferentes tecnologias e provocou mudanças no cotidiano dos citadinos e transformações na organização do espaço urbano. Vale salientar que os diferentes tipos de iluminação pública provocaram grandes transformações no cotidiano da população destas cidades que aos poucos vão ganhando a possibilidade de terem uma vida noturna, deste modo se afastando da "escuridão" dos séculos anteriores, quando a iluminação pública era quase inexistente. (MAIA et al, 2009:2-3)

A partir da implantação da iluminação, a população passa a apresentar hábitos noturnos mais acentuados, tem-se o crescimento e florescimento de novas atividades, modificando o hábito das ruas da cidade. As ruas ganham nova vida modificando assim sua dinâmica de interação. $\mathrm{O}$ passeio público ganha à noite. Uma faceta da cidade até então encoberta se desnuda ao olhar. A cidade, desta forma se configura como o lugar no qual fato e imaginário se fundem.

O crescimento da cidade também é possibilitado pelo deslocamento do eixo da economia do campo para a cidade. O surto manufatureiro-industrial que sucedeu à decadência cafeeira do Vale do Paraíba teve consequências diretas na estruturação do espaço urbano. A opção pelo investimento na cidade contribuiu fortemente para o seu crescimento desordenado. O número de habitantes aumentou significativamente neste período. Em 1838 a população da cidade do Rio de Janeiro era de 137.087 habitantes, já em 1890 esse número tinha aumentado para 522.651 habitantes. (RIBEIRO \& PECHMAN, 2008). O grande número de habitantes somado a carência de moradias possibilitou o surgimento de 
precárias habitações no centro da cidade, tais como: cortiços, estalagens, vilas populares, casas de cômodos, entre outras.

Viver próximo ao centro não era uma questão de escolha, mas de necessidade. Estar bem localizado no espaço urbano, principalmente para aqueles que não dispunham de transporte próprio e que não teriam condições de pagar por um transporte coletivo, era condição vital para a permanência na cidade. A relação emprego-moradia era como que orgânica, não se podendo pensar no transporte como elemento articulador desses dois espaços. (RIBEIRO \& PECHMAN, 2008: 47).

"A cidade em expansão procurava novas áreas para ocupar, sendo a Lapa a opção preferencial por sua proximidade em relação ao centro.”. (DUARTE, 2009:4). Esse quadro de concentração de empregos e moradias, no centro da cidade, abria espaço à valorização imobiliária. Com o aumento do preço dos aluguéis, a única alternativa para os grupos de menor renda era o aluguel de precárias habitações coletivas. Essas construções, com péssimas condições de moradia, contribuíam para um quadro urbano confuso e insalubre. No fim do século XIX, assiste-se, simultaneamente ao processo de inchaço populacional do centro, a uma evasão da elite em direção à zona sul da cidade, que passa a representar uma nova opção de moradia.

Com a elevação do Rio de Janeiro à condição de Distrito Federal e sede do governo republicano, em 1889, a velha estrutura urbana deveria ser transplantada, "fazia-se necessária a remodelação da cidade, para que a ordem e o progresso civilizatórios fossem encenados.” (GOMES, 2008:113). Tal remodelação foi implementada durante a administração do Prefeito Pereira Passos (1902-1906), período conhecido como "Bota-abaixo", e visava saneamento, urbanismo e embelezamento, a fim de atrair capital estrangeiro e dar ao Rio de Janeiro ares de cidade moderna e cosmopolita. 


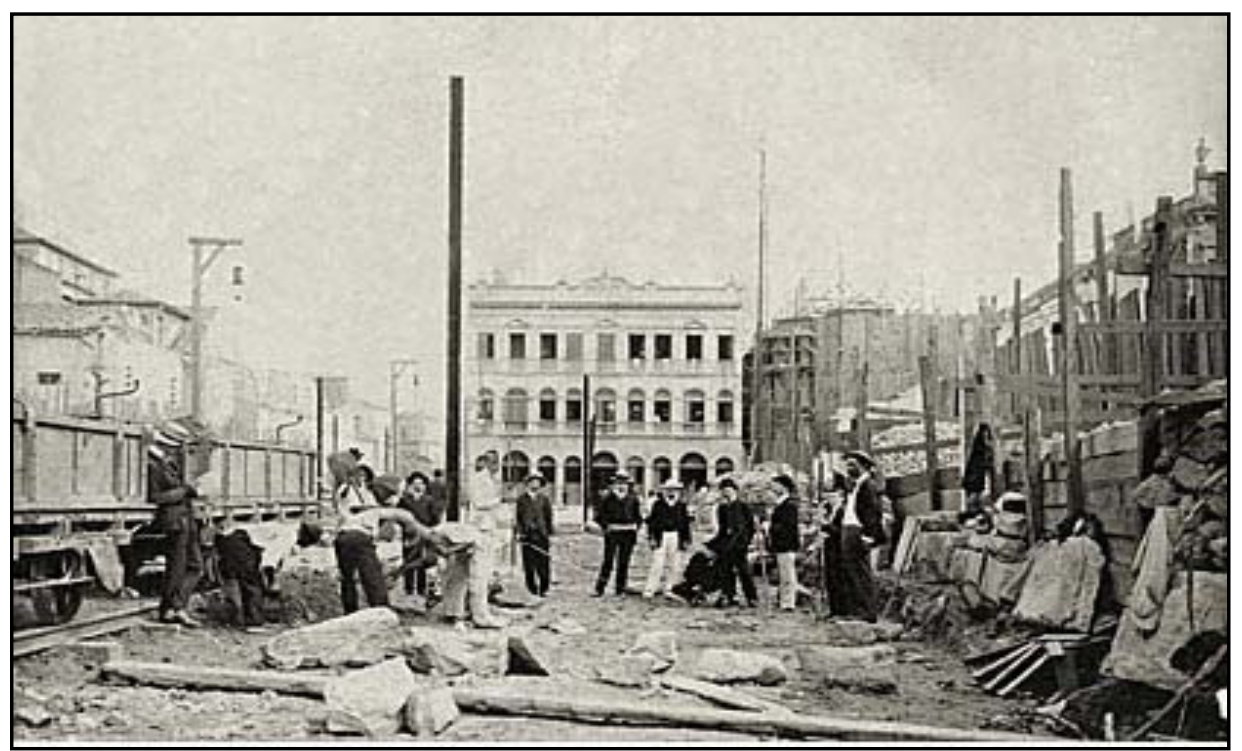

Figura 8 - Demolições para a construção da Avenida Central (1904 - 1905) - João Martins Torres - Acervo Instituto Moreira Sales

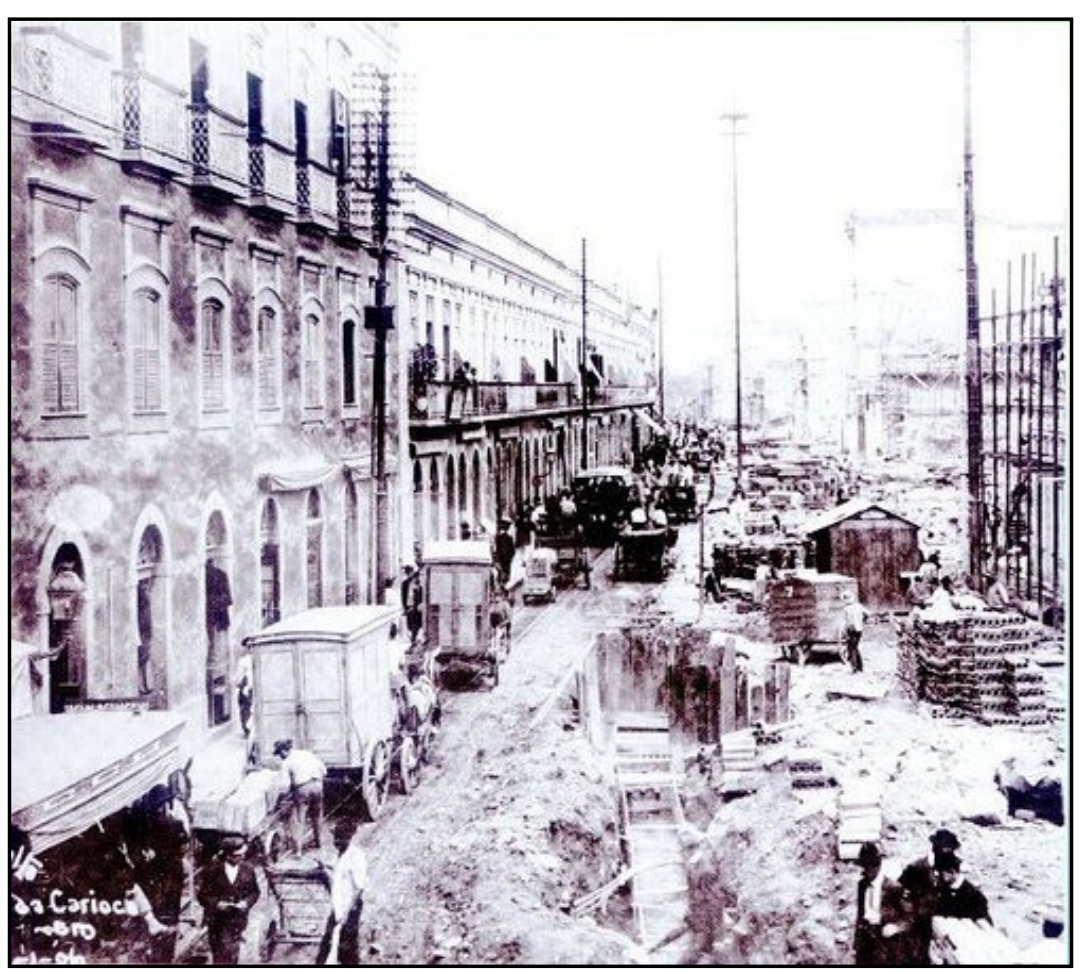

Figura 9 - Demolições no centro da cidade do Rio de Janeiro. Disponível em: http://www.revistadehistoria.com.br/secao/reportagem/passado-quecondena - Acesso: em 29/ 08/ 2012. 
Inspirado nas reformas de Haussmann ${ }^{3}$, Pereira Passos transforma a aparência da cidade. Com a finalidade de saneamento e ordenação da malha de circulação viária, demoliu casarões, conforme podemos ver nas Figuras (2 e 3) acima, abriu diversas ruas e alargou outras. O alargamento das ruas permitiu arejamento, higienização da cidade, ventilação e melhor iluminação do centro e ainda a adoção de uma arquitetura de padrão superior. Aos cortiços e ruas estreitas e escuras, sobrevieram grandes bulevares, com imponentes edifícios, dignos de representar a capital federal. Surgem novas construções afeiçoadas à arquitetura parisiense, tais como a Biblioteca Nacional o Teatro Municipal, a e o Escola de Belas Artes (esses dois último podem ser visto na figura 4, a seguir), destinadas a compor o cenário arquitetônico das avenidas recém-inauguradas.

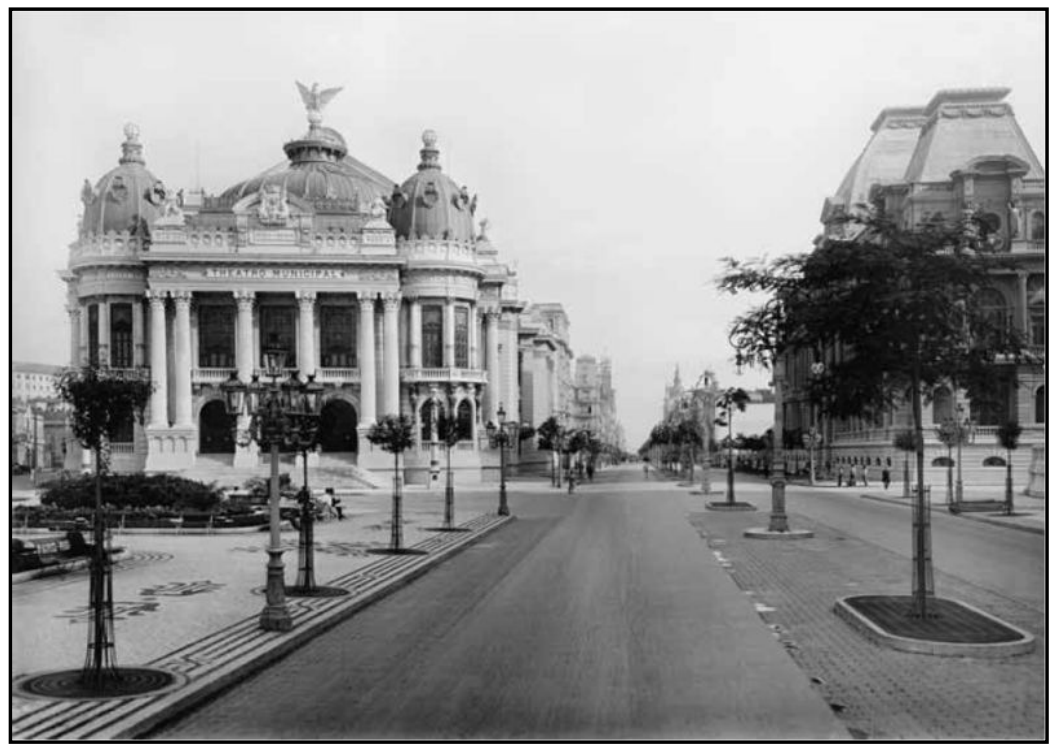

Figura 10 - Vista da Avenida Rio Branco em 1909. À esquerda, vê-se a Praça Floriano Peixoto e o Theatro Municipal do Rio de Janeiro; à direita, a Escola Nacional de Belas Artes. Foto de Marc Ferrez. Esta imagem está no domínio público porque os respectivos direitos de autor expiraram. Disponível em: In: http://pt.wikipedia.org/wiki/Avenida_Central. Acessado em: 23/10/2012

\footnotetext{
3 Prefeito do antigo departamento do Sena (que incluía os atuais departamentos de Paris, Hautsde-Seine, Seine-Saint-Denis e Val-de-Marne), entre 1853 e 1870. Responsável pelo projeto de modernização e embelezamento da cidade.
} 
Retirou-se do centro da cidade a presença dos humildes, permitindo que a burguesia e a aristocracia ganhassem as ruas, conhecendo e desfrutando de um novo Rio de Janeiro: são, livres das doenças, e belo, de rosto e corpo parisiense.

É de olho no moderno que os donos do poder geram para o Rio de Janeiro o sonho da cidade racional, higiênica e controlável. São os tempos eufóricos da visão oficial, que ocupam o centro da cena, das primeiras encenações do Rio como capital federal. (GOMES, 2008: 115).

Para inserir o Brasil no mundo modernizado e conferir ao país o status de nação "civilizada", foram tomadas algumas iniciativas administrativas, tais como:

\begin{abstract}
A condenação dos hábitos e costumes ligados pela memória à sociedade tradicional; a negação de todo e qualquer elemento da cultura que pudesse macular a imagem civilizada da sociedade dominante; uma política rigorosa de expulsão dos grupos populares da área central da cidade, que será praticamente isolada para desfrute exclusivo das camadas aburguesadas; e um cosmopolitismo agressivo, profundamente identificado com a vida parisiense. (SEVCENKO, 2003: 43)
\end{abstract}

O Rio transformava-se, abria caminhos para a absorção e difusão dos novos hábitos e costumes do mundo europeu. Tornava-se o centro cosmopolita do país. Com o advento da modernidade, urgia a necessidade de destruição, e consequente reconstrução da cidade, que carregava o ranço da velha sociedade imperial. A nova estrutura urbana importava e copiava o modelo da moderna cidade de Paris.

A "destruição" modernizadora de Pereira Passos se concentrava em limpar o centro da cidade. Ao realizar a expulsão dos pobres, além do processo de favelização ocorrido em alguns pontos da cidade, pôde-se verificar a formação do cinturão de pobreza que circundava o centro da cidade. "Tal fenômeno deve ser creditado à baixa mobilidade urbana dos pobres, já que um eventual aumento da distância entre o local de moradia e o local de trabalho (ou de concentração de ofertas de trabalho) significaria um custo adicional de transporte incompatível com seus rendimentos." (DUARTE, 2009:6)

Ao ser retirada do centro, a população de baixa renda teve que deslocar. Os primeiros deslocamentos foram para a zona portuária, avançando em direção à Cidade Nova, onde se localiza a região do Canal do Mangue. A Lapa com seus 
ricos sobrados e palacetes não tardaria a fechar o arco da pobreza em torno do centro.

O "fechamento" desse arco de pobreza foi facilitado pelo arrasamento do morro do Senado, em 1905, e pela abertura da Avenida de Mem de Sá ${ }^{4}$ que cortava diagonalmente toda a Lapa.

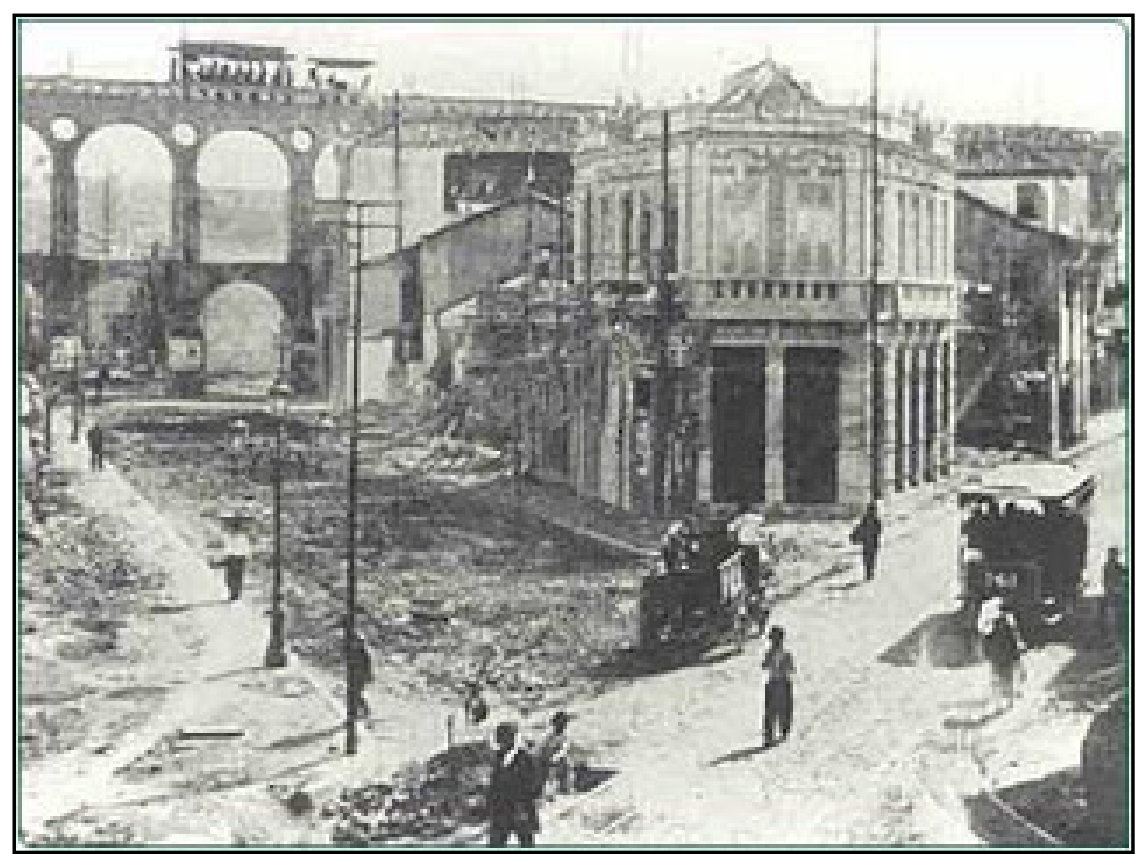

Figura 11 - Abertura da Avenida Mem de Sá em 1904 - Disponível em: http://caipirinhadebarril.blogspot.com.br/2010/01.htm. Acesso em 12/07/2013.

A abertura dessa via constituía-se em uma tentativa de aproximação entre a Lapa e o centro urbano, no entanto, esse novo eixo estendia-se até a Cidade Nova, o que acelerou o fechamento desse cinturão de pobreza em um semicírculo, envolvendo o centro da cidade, como se pode verificar na Figura 6, a seguir:

\footnotetext{
${ }^{4}$ Maior obra depois da Avenida Beira-Mar. É uma via diagonal destinada a ligar a Lapa à Tijuca e a São Cristóvão, através das Ruas Frei Caneca, Salvador de Sá e Estácio de Sá: tem 17m de largura e $1.550 \mathrm{~m}$ de extensão. In: Plano de Melhoramentos Pereira Passos - Plano de Embelezamento e Saneamento da Cidade. PEREIRA PASSOS, Francisco. PLANO URBANÍSTICO - Rio de Janeiro: Biblioteca: Arquivo Geral da Cidade do Rio de Janeiro AGCRJ- Cidade Objeto: Rio de Janeiro - Rio de Janeiro. Disponível em: http://www.urbanismobr.org/bd/documentos.php?id=2714. Acesso em: 24/10/2013
} 


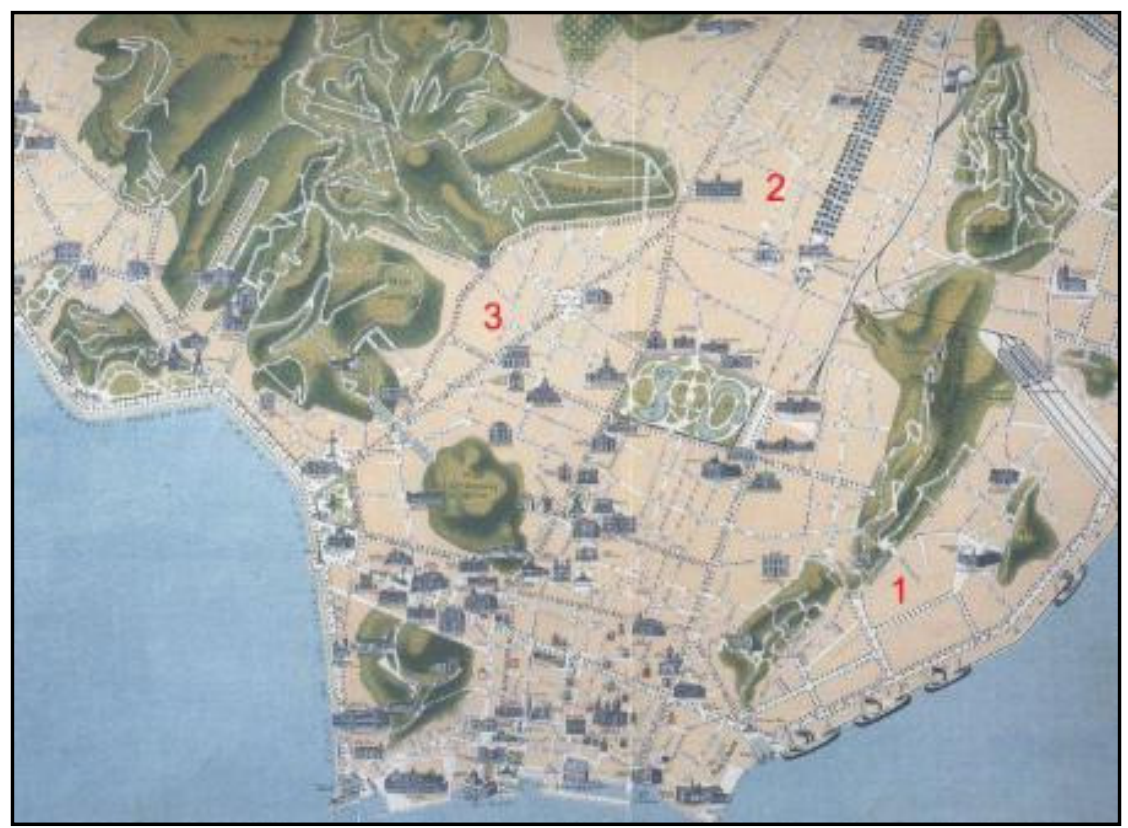

Figura 12- "Rio de Janeiro - Central Monumental, 1914". Instituto Histórico e Geográfico Brasileiro. Rio de Janeiro. O "cinturão de pobreza" formado pelos bairros: 1) Saúde e Gamboa (zona portuária); 2) Cidade Nova; 3) Lapa. In Duarte, 2009.

Com essa reforma excludente que retira os pobres do centro da cidade, há uma grande procura pelos bairros adjacentes. Desta forma, ao longo das duas primeiras décadas do século XX a Lapa vai se inflando de moradores pobres que passam a ocupar os ricos palacetes. $\mathrm{O}$ estigma da malandragem recaiu sobre o local. De suas nobres origens e seu passado essencialmente familiar, tornou-se refúgio de boemia, jogatina e de prazer para aqueles que frequentavam o centro político e cultural do então Distrito Federal. A região recebia poetas, músicos, artistas e políticos, que residiam e conviviam em perfeita harmonia com malandros, prostitutas e pobres que lá estavam.

Com a desvalorização do bairro da Lapa, por um lado, e a vantagem de sua proximidade com o Centro, por outro, um espaço significativo de suas casas passa a ser ocupado, sob forma de aluguel de quartos em pensões, casas de cômodos ou mesmo em casas de famílias, por um grande número de rapazes solteiros. Com isso junto com as famílias de imigrantes surgem como moradores também, um contingente formado (embora não só) de jovens estudantes, jornalistas, escritores e artistas uns pobres outros não - que vinham tentar a vida no grande centro urbano constituído pela cidade do Rio de Janeiro. (COSTA, 1993: 197 -198) 
Além das reformas de embelezamento e saneamento na cidade do Rio de Janeiro, a adoção de um modo de vida com ares parisienses, contrastando com a pobreza que circundava o centro modificado, contribuiu para a criação de um terreno fértil no qual novas identidades puderam ancorar.

A identidade é um elemento chave para a compreensão dos fenômenos sociais, uma vez que, apoiada nas teorias de Luckmann e Berger (2002: 221), acha-se em relação dialética com a sociedade, é formada no bojo nos processos sociais, que por sua vez são determinados pela estrutura social. As identidades produzidas "reagem sobre a estrutura social dada, mantendo-a, modificando-a ou mesmo remodelando-a". Esta pesquisa contempla a formação de duas identidades essenciais para a compreensão da formação, e destruição (ou tentativa), do imaginário lapiano: o boêmio e a prostituta.

\section{2.}

\section{A Lapa Boêmia}

As mudanças ocorridas na configuração das cidades, em fins do século XIX e início do século XX, que buscavam inserir o Rio de Janeiro no chamado "mundo civilizado" proporcionou novos tipos de lazer, sociabilidade e prazer. Tal período foi extremamente profícuo ao aparecimento de personagens que desafiaram as regras sociais de boa conduta. Boêmios, malandros e prostitutas reproduziram-se em larga escala pela cidade que se modernizava. As severas regras de conduta, impostas pela elite político-econômica, abriam espaço para modelos alternativos ao que se propunha ideal. Os que de forma mais evidente entravam em choque com a moral burguesa eram associados a um universo de marginalidade e transgressão. No entanto, a sociedade patriarcal, racional, burguesa necessitava de meios para saciar seus impulsos febris; desta forma, os bordéis funcionavam como fuga para uma sociedade que trabalhava de dia e tinha diversas limitações morais e sexuais

A Lapa dita boêmia começou a florescer por volta de 1910. Segundo Gasparino Damata (2007:22), nesse período a Lapa possuía dupla personalidade, 
revezando-se entre a vida noturna e boêmia de uma elite política e a vida diurna de residências familiares. Apesar de ser tornar um território povoado pelo "pecado", a Lapa continuava resguardando a sua faceta diurna inocente, com seu convento, seus pequenos armazéns, farmácias, barbearias e pensões familiares. Ao apagar das luzes, as pessoas reuniam-se para beber, comer, dançar, brigar, amar e então a inocência cedia espaço às lâmpadas vermelhas que se acendiam no interior dos quartos.

A Lapa possuía uma frequiência heteróclita, funcionários públicos, jornalistas, profissionais da classe média, intelectuais boêmios e jovens de famílias tradicionais, amantes da aventura, misturavam-se livremente com escroques e ladrões de fim de semana, apostadores, cafetões, frescos e putas e com personalidades literárias do movimento modernista, artistas e estrelas em ascensão nos círculos intelectuais brasileiros. (GREEN, 2003).

\subsection{1. O fenômeno da boemia e os boêmios da Lapa}

Os boêmios são frutos da modernidade. A boemia nasce no mundo posterior à Revolução Francesa, no qual temos o florescimento da indústria, o deslocamento da vida política, econômica e cultural do campo para a cidade e as revoluções burguesas. As grandes áreas urbanas se desenvolvem e nelas surge a boemia. Se por um lado, foi a modernidade que possibilitou que a figura do boêmio viesse a lume, por outro, ele é a figura que concentra a resistência mais radical à vida moderna.

A modernidade costuma ser entendida como um ideário e está relacionada ao projeto de mundo moderno, empreendido em diversos momentos ao longo da Idade Moderna e consolidado com a Revolução Industrial, estando normalmente relacionada ao desenvolvimento do Capitalismo. O fluxo migratório para as cidades é intenso durante esse período, o homem do campo parte para a metrópole industrializada. Com o advento da modernidade, a vida urbana se sobrepõe à rural. O processo migratório do homem para a cidade permite que essa cresça 
vertiginosamente, o pertencimento à cidade faz do indivíduo um ser coletivo, “todos são iguais em uma multidão" (SANTOS, 2009:112)

\begin{abstract}
A modernidade trouxe para o homem, além do progresso, o anonimato. $\mathrm{O}$ anonimato metropolitano suscitou, nos primeiros que percorreram as cidades, angústia, repugnância e medo, pois transformou o indivíduo em um ser coletivo. Cria-se o conceito de uniformidade. Nessa uniformidade, o homem se comporta como autômato, repetindo gestos e comportamentos. A sociedade se converte em massa social, em que todos agem mecanizados por seus trabalhos em esteiras automáticas, de forma que parecem não poder mais se exprimir senão de maneira idêntica. (SANTOS, 2009:112)
\end{abstract}

A boemia lutava contra essa uniformização imposta pela centralidade, afrontando a mediania das "classes superiores". Franklin de Oliveira (2008) entende por centralidade todos os que já gozavam de papéis sociais definidos, poderio econômico e influência política relativamente estáveis. Esta estabilidade, característica da burguesia, passa a servir de alvo ao achincalho boêmio, uma vez que este entrava em dissonância e afrontas a certos aspectos conservadores das formas de vida na cidade centralizada. A cidade, desta forma, configura-se como a cidade da opinião, adotando o conceito Paul Ricoeur (2006), na qual o renome e a grandeza não dependem senão da opinião dos outros, com os vínculos da dependência pessoal decidindo a importância aos olhos de outrem. Neste local, a honra depende do crédito conferido por outrem.

O grande representante desse modo vida moderno era o burguês. Quando a sociedade se converte em industrial e capitalista, há a ascensão da burguesia. Desde o seu nascimento a boemia se torna antagonista do pensamento burguês. Este conflito surge no âmago da vida burguesa, visto que "a boemia expandiu-se onde limites da existência burguesa eram obscuros e incertos". (SEIGEL, 1992: 19). Para Seigel, boêmios e burgueses são como pólos magnéticos positivos e negativos, são partes de um mesmo campo: se exigem e atraem um ao outro. "A boemia, portanto, deve ser enquadrada exatamente no fulcro do dilema burguês: o interesse egoístico do capital por um lado, os ideais de emancipação e de liberdade do homem pelo outro. Ela é corpo e delito dessa angústia" (OLIVEIRA 2008, 32). Boêmios e burgueses ajudam-se a definir mutuamente. 
Não se pode compreender a experiência que os escritores e os artistas puderam ter das novas formas de dominação as quais se viram sujeitos na segunda metade do século XIX, e o horror que a figura do "burguês" por vezes lhes inspirou, se não se tem uma ideia do que representou a emergência, favorecida pela expansão industrial do Segundo Império, de industriais e de negociantes com fortunas colossais, novos-ricos sem cultura dispostos a fazer triunfar em toda a sociedade os poderes do dinheiro e sua visão do mundo profundamente hostil às coisas intelectuais. (BOURDIEU, 1996: 64)

Ser boêmio significava construir-se pela negação dos valores burgueses. O oposto do burguês não é o proletário, escreveu Oswald de Andrade (1933) ${ }^{5}$, mas o boêmio. Kehl (2011), afirma que somente o boêmio encarna o desapreço pelo conforto e pelo dinheiro, a recusa a se deixar explorar, a aceitação da pobreza como preço pago pelo encantamento de uma vida livre ligada à orgia, à poesia, ao amor e à música. De acordo com Fonseca (2007), as regras de concretização na sociedade do triunfo da Razão eram o trabalho, a família, a religião, os valores da sobriedade, do rigor, da honra, da gestão racional dos prazeres e paixões, da privacidade, da clara delimitação do lugar e da função de cada indivíduo no tecido social.

O boêmio era, então, a negação de tudo isso. Era o protagonista do lazer, do excesso, da passionalidade, da fruição dos prazeres, do efémero, da ausência (quase !) completa de uma gestão racional da conduta humana, sem respeito pelas bases da moral, da família e da religião. (FONSECA, 2007: 23)

O boêmio é, portanto, um elemento exterior e transgressor dessas regras, o ócio boêmio, em contraposição ao trabalho burguês, é visto como crime nesta sociedade essencialmente produtiva e especializada. Os sinais externos da boemia - o vestuário extravagante, os cabelos longos (muitas vezes identificados como falta de asseio), a liberdade sexual, a ingestão de bebidas e drogas, os hábitos de vida noturna, os padrões irregulares de trabalho, entre outros, entravam em choque direto com a vida linear e sóbria dos burgueses (SEIGEL, 1992). Um ponto fundamental para a formação da identidade boêmia é a oposição à figura do burguês.

\footnotetext{
${ }^{5}$ Prefácio de Serafim Ponte Grande.
} 
De acordo com Oliveira (2008), os boêmios compartilhavam uma existência baseada na recusa ou na incapacidade de aceitar uma identidade social estável e limitada. Viviam ao mesmo tempo dentro e fora da sociedade organizada. E é a cidade, exatamente, o espaço por excelência de realização desses combates existentes entre o pensamento burguês e o boêmio, definidos pela modernidade na qual estão inseridos. Se a boemia é um fenômeno eminentemente urbano, não se pode deixar de analisar a experiência desse grupo em termos espaciais, ou seja, a vivência dos boêmios no espaço da cidade.

A renitência dos boêmios em combater a modernidade que os gerou é compreensível pela própria complexidade da cidade que tende a suprimir aqueles que adotam condutas irracionais e soberanas, alheias aos quadros de funções sociais e dos postos da cadeia produtiva. O indivíduo na verdade protesta com sua vivência errante e sua insistência em não aceitar papéis sociais estáveis contra o fato de ser desnecessário para a cidade. Sem função na modernidade reflete sobre si mesmo ao se confrontar com a cidade (OLIVEIRA, 2008: 32).

A modernidade é extremamente paradoxal, carregado de ambiguidades, visto que ao mesmo tempo em que oferece certezas e seguranças, gera dúvidas e inseguranças. "Ser moderno é encontrar-se em um ambiente que promete aventura, poder, alegria, crescimento, autotransformação e transformação das coisas em redor - mas ao mesmo tempo ameaça destruir tudo o que temos, tudo o que sabemos, tudo o que somos" (BERMAN,1986: 14). Para Baudelaire (1995: 859), a modernidade "é o transitório, o efêmero, o contingente, é a metade da arte, sendo a outra metade o eterno e o imutável”.

A maioria dos poetas que trataram desses assuntos realmente modernos contentou-se com temas estereotipados, oficiais - esses poetas preocupam-se com nossas vitória e nosso heroísmo político. Mas fazemno também de mau grado, e apenas porque o governo os ordena e lhes paga. Mas existem temas da vida privada. Mas existem temas da vida privada muito mais heróicos. O espetáculo da vida mundana e de milhares de existências desordenadas; vivendo nos submundos de uma grande cidade. ( BAUDELAIRE apud BENJAMIN, 2000: 16)

Para viver a modernidade, ressalta Benjamin, é necessário ter uma formação heróica. E Baudelaire penetra nessa figura do herói, ao tratar dos temas do cotidiano. Segundo Harvey, Baudelaire logo percebeu que se o fluxo e a 
mudança, a efemeridade e a fragmentação formavam a base material da vida moderna, então a definição de uma estética que representasse o moderno dependia de maneira crucial da posição do artista diante do processo. "O artista individual podia contestá-los, aceitá-los, tentar dominá-los ou apenas circular entre eles, mas o artista nunca os poderia ignorar" (HARVEY, 2006: 29).

Se voltarmos à formulação de Baudelaire, vemo-lo definindo o artista como alguém capaz de concentrar a visão em elementos comuns da vida da cidade, compreender suas qualidades fugidias e ainda assim extrair, do momento fugaz, todas as sugestões de eternidade nele contidas. (HARVEY, 2006: 29).

Entender a cidade é entender a modernidade. Cidade e modernidade são duas categorias que não podem ser analisadas separadamente, estão imbricadas. "A cidade é o laboratório e o palco da modernidade" (PEREZ, 1998: 13). E como metonímia desse espaço - o conceito de espaço aqui é polissêmico, visto que ele é ao mesmo tempo físico, social, econômico, cultural, político - temos a rua. No espaço da rua eclodiam todos os tipos de relações humanas. A rua é o acontecer da modernidade. Suas transformações dramatizam as mudanças que sociedade e a cidade estavam vivendo.

\begin{abstract}
A rua é a civilização da estrada. Onde morre o grande caminho começa a rua, e, por isso, ela está para a grande cidade como a estrada está para o mundo. Em embrião, é o princípio, a causa dos pequenos agrupamentos de uma raça idêntica. Nas grandes cidades a rua passa a criar o seu tipo, a plasmar o moral dos seus habitantes, a inocular-lhes misteriosamente gostos, costumes, hábitos, modos, opiniões políticas (RIO, 1997: 14).
\end{abstract}

Há uma relação muito forte entre os indivíduos, a sociedade e a rua. Eles interagem e se influenciam reciprocamente. São um contínuo, uma extensão uns dos outros. A rua é o espaço que cria a unanimidade, mas é também aquele da diversidade. A rua é o lugar nivelador das diferenças. De acordo com Oliveira (2008), a rua se configurava como o lugar por excelência do embate paradoxal existente entre a boemia e os burgueses. Local do capitalismo, do consumo desenfreado, mas ao mesmo tempo local de passagem da boemia, ou melhor, de morada boêmia. Para Nilton Rodrigues (2006), a rua se configurava como um espaço de circulação por excelência, no qual as pessoas afluíam em busca de 
novas mercadorias e de posição social no jogo ver e ser visto, criando laços sociais e construindo um imaginário urbano que se instaura na dicotomização entre o público e o privado, a casa e a espaço urbano. A boemia era acolhida pela rua não somente pela flexibilidade dos padrões morais ali permitidos, mas por não ter outro lugar aonde ir, ou por não querer ir a outro lugar. No espaço da rua, os boêmios experimentavam os mais diversos tipos de relações.

Não se pode falar de rua, boêmia e modernidade sem tocar no cerne da questão: a experiência urbana. A experiência urbana propriamente dita, com as andanças pela cidade moderna que se ergue era correlativa à busca da individualidade e da subjetividade, em uma sociedade que se propunha uniformizante. Franklin de Oliveira (2008) revela que elementos constitutivos da boemia foram justamente os dilemas da individualidade/subjetividade, das relações infra-sociais urbanas e da busca por uma forma renovada de arte. Sendo assim, a boemia vivia em um constante conflito sobre os limites do individualismo e da existência burguesa, sobre a subjetividade livre (que se reivindica e constrói na modernidade) e sobre sua conversão em egoísmo e conformismo (SEIGEL, 1992). A relação com o universo de circulação na cidade, bem como a vivência no "grupo primário" são elementos constitutivos da subjetividade boêmia.

Seria conveniente dissociar radicalmente os conceitos de individuo e de subjetividade. O indivíduo é serializado, registrado, modelado. A subjetividade não é passível de totalização ou de centralização no indivíduo. (...) a subjetividade é essencialmente fabricada e modelada no registro social. A subjetividade não se situa no campo individual, seu campo é de todos os processos de produção social e material (GUATTARRI \& ROLNIK,1986: 31-32).

Segundo Guattari \& Rolnik (1986), o modo pelo qual os indivíduos vivem essa subjetividade oscila entre dois extremos: uma relação de alienação e opressão, na qual o indivíduo se submete à subjetividade tal como a recebe, ou uma relação de expressão e de criação, na qual o indivíduo se reapropria dos componentes da subjetividade, produzindo um processo chamado de singularização. A singularização é a frustração dos mecanismos de produção de subjetividade. Os boêmios ao captarem os elementos da cidade, ao se tornarem 
leitores da sociedade, ao se recusarem a adotar padrões estabelecidos pela burguesia, se singularizavam.

O que vai caracterizar um processo de singularização é que ele seja automodelador. Isto é, que ele capte os elementos da situação, que construa seus próprios tipos de referências práticas e teóricas, sem ficar nessa posição constante de dependência em relação ao poder global (...) A partir do momento em que os grupos adquirem essa liberdade de viver seus processos, eles passam a ter uma capacidade de ler sua própria situação e aquilo que se passa em torno deles. Essa capacidade é que vai lhes dar um mínimo de possibilidade de criação e permitir preservar exatamente esse caráter de autonomia tão importante (GUATTARI \& ROLNIK, 1986:46)

Fonseca (2007) atenta para o fato de que a definição de boemia se revela enquanto modo de vida, não como condição social ou material. Desta forma, qualquer indivíduo de diversa origem, berço ou linhagem poderia ser boêmio. Na contramão desse pensamento, Benatti (1996), ao analisar o artigo "Nossos tipos: o boêmio", transcrito a seguir, publicado na Folha de Londrina, em maio de 1952, define o boêmio como uma espécie de extravagante ocasional, mais aceito que estigmatizado, oriundo dos quadros sociais médios ou superiores, perfeitamente integrado à estrutura produtiva e aos valores dominantes da sociedade. "De noite, um boêmio; de dia, um cidadão de prol."

Esse nosso tipo é um dos mais originais no país, pois é hoje muito rara a cidade do Brasil em que não se ache um boêmio. Há só duas classes de boêmios conhecidas. $\mathrm{O}$ verdadeiro boêmio e o impostor, que quer fazerse passar por boêmio. O verdadeiro boêmio geralmente é um rapaz de bons princípios. Gosta da boêmia assim como poderia gostar de estudar ou outra qualquer ocupação que mate o seu tempo. Tem um pouco de cada coisa, como seja: bebe, fuma, joga no mais das vezes todos os jogos do "continente", entende a gíria do malandro mas não a pratica, a não ser uma ou outra palavra. Raramente dorme à noite, a não ser por algo excepcional. Bebe tôda a sorte de bebidas alcoólicas, desde a nossa "branquinha" até o "Whisquey" americano. Frequienta tanto uma "gafieira" como uma "boite" ou "dancing" ou um "cabaret", assim como também sabe portar-se dignamente em um ambiente familiar.

$\mathrm{O}$ verdadeiro boêmio gosta de nossa música, mas escolhe quase sempre para suas "rodinhas" o tango argentino ou os clássicos boleros, hoje muito em moda. Gosta de cantar nem que seja desafinado e em geral todos eles têm a sua música predileta, pois esse tipo de boêmio é muito sentimental, não incomodando-se nunca em fazer o bem (sic).

O outro tipo, esse é... o indesejável em qualquer roda, a ovelha negra das "madrugadas", pois quase sempre é "bêbado", "escroque", "gatuno" ou "vigarista". Não gosta de "batente", seja ele qual for, e volta e meia está dando trabalho para o policiamento da cidade. Dizem-se boêmios porque, 
infelizmente, há alguns compositores nossos que dizem em suas melodias que o boêmio é tudo isso e eles querem seguir o que ouvem, porque são de índole perversa e má. Não respeitam ninguém; o que eles querem é a malvadês, sendo que vivem procurando encrenca em qualquer ambiente, não importando-se em brigar com velhos, aleijados, cegos ou doentes; querem é ter assuntos para gabarem-se na noite seguinte. Com essa classe é que a nossa polícia deveria acabar, pois só assim o verdadeiro boêmio não seria incomodado em suas brincadeiras, já que este em geral não é nenhum "arruaceiro" e não procura encrenca. A não ser que haja algum "engraçadinho" que queira passá-lo para trás, ou fazê-lo de otário, aí então o nosso boêmio dá a "bronca", e às vezes tão grande que agita uma cidade inteira, pois é um rapaz bem amistoso e querido por todos.

Por meio de oposições binárias, o excerto acima define o que seria a boemia: um divertimento menor para um jovem burguês. Boemia e burguesia seriam, portanto, dois lados de uma mesma moeda. O "verdadeiro boêmio" faz parte de uma espécie de elite na sociabilidade da vida noturna. Tal definição de boemia contraria as anteriores, que posicionam os boêmios na linha de frente da artilharia contra o modo de vida e as crenças burguesas? Não, ela somente traz à tona mais um paradoxo relativo ao "ser boêmio". O boêmio é, portanto, um submisso ou um rebelado?

O boêmio, tipo ambíguo, permanece o que sempre foi: com um pé em cada lado da linha que separa e ao mesmo tempo une centro e as margens. Apesar de tudo, a fuga boêmia, por sua simples existência, pode ser vista como uma crítica velada à sociedade burguesa e suas imposições ideológicas e disciplinares. O tempo gasto no prazer erótico, lúdico e dionisíaco - tempo do ócio, da fruição gozosa da vida -, evidencia a temporalidade do trabalho como uma forma de vivência do tempo, e não $o$ tempo natural, único, universal. (BENATTI, 1996: 215).

Estamos falando de uma experiência urbana, moderna e paradoxal - a boemia - e tentar resolver esse paradoxo empobrece nossa compreensão da experiência histórica real, visto que são os contrastes, as ambigüidades e os paradoxos as grandes características da vivência boêmia. A boemia encontravase na interseção da cidade moderna. Os boêmios, com sua existência limítrofe, podiam transitar por diferentes níveis de realidade sem, no entanto, pertencer a nenhum deles. Encontravam-se no entre-lugar, na terceira margem do rio. A boemia nasce do choque de contrários. 
A figura do boêmio é imprescindível para a compreensão da sociedade carioca, visto que ela se encontra na intermitência de dois mundos que se excluem mutuamente. A boemia carioca é fruto da modernização da cidade. A cidade modernizada, que não dorme, é um convite para os jovens que desejam experimentar uma sensação de liberdade distante do seio familiar.

O lar familiar é substituído por moradias passageiras. As mulheres, símbolos de uma vida doméstica, são socializadas como tudo mais que possam possuir momentaneamente, afastando qualquer possibilidade de laços que remetam à vida privada burguesa. Sem se distanciarem de suas atividades, estes boêmios tomam locais públicos noturnos para suas discussões e produção. (VELASQUES, 1994:19)

A Lapa é um desses lugares tomados pela boêmia. Suas leiterias ${ }^{6}$, restaurantes e cabarés tinham as noites movimentadas e recebiam uma gama variada de intelectuais. No primeiro terço do século XX, a Lapa recebeu a alcunha de Montmartre Carioca. A feição de Montmartre $^{7}$ em miniatura, de acordo com Martins, surgiu na década de 20, na Lapa de cronistas, poetas, teatrólogos, romancistas, compositores, caricaturistas, "todos jovens, alguns já célebres, outros ainda principiantes, mas nenhum deles anônimo" (CASTRO, 2004:18). Martins atenta para o fato de que antes da aparição deste grupo, ainda não se havia construído na Lapa uma tradição artística e intelectual, poucos cronistas do começo do século se ocuparam dela, e a boemia literária da época ${ }^{8}$ não a frequentava. “A Lapa não era um bairro literário”. (MARTINS, 1979:36)

\begin{abstract}
A boemia literária do tempo de Bilac, além da "Colombo", do "Pascoal" e dos "Castelões", bares vespertinos, reunia-se à noite, em cervejarias e "clubes da Praça Tiradentes e adjacências; a do tempo dos simbolistas, quando muito, seria habituée dos "chopes" e cafés-cantantes da rua do Lavradio. (MARTINS, 1979:36)
\end{abstract}

\footnotetext{
6 "havia, na cidade, 251 leiterias e cafés-leiterias" FERNANDES, Millor. In: DAMATA, Gasparino. Antologia da Lapa. $3^{\mathrm{a}}$ Ed. - Rio de Janeiro: Desiderata, 2007. p. 10.

7 "A Paris boêmia e a avant-garde modernista ocuparam um território comum- as ruas e praças de Montmartre" (SEIGEL, 1992: 339). Montmartre é uma colina no norte de Paris e seu nome aparece quase como sinônimo da época heróica da arte do século XX.

8 Boemia literária de 1870. Integravam este grupo, denominado boêmio, além de Coelho Netto, Aluisio Azevedo, Artur Azevedo, Guimarães Passos, Olavo Bilac, Pardal Mallet, entre outros.
} 
Raul de Leôni, Ribeiro Couto, Jayme Ovalle, Caio de Mello Franco, Di Cavalcanti, Oswaldo Costa, Sergio Buarque de Hollanda, Dante Milano, Luiz Peixoto, Álvaro Moreyra, Paulo Magalhães, Joracy Camargo, Cornélio Pena, Villa-Lobos, Hernani do Irajá, Alberto Deodato, Roberto Rodrigues, e Manuel Bandeira, somente em fugazes aparições, "parece esquivo, intermitente e raro, porque a saúde frágil e comprometida não lhe permitia excessos de vida desregrada”, (MARTINS, 1979:34), foram responsáveis pela criação da versão montmartriana dos trópicos.

A feição de Montmartre em Miniatura surgiu, assim, aí pelo início da década de 20, ou fins da anterior, nos anos da mocidade boêmia de Raul de Leôni, Jaime Ovalle, ribeiro Couto, Di Cavalcanti, etc. Em alguns desses homens a lembrança desses dias felizes perdurou para sempre. A Lapa sublimou-se em imagem de paraíso perdido. (MARTINS, 1979:36)

A década de 20 foi o período de descoberta da Lapa pela geração intelectual modernista. Damata (2007) diz que a Lapa desse período tinha o sabor um Montmartre caboclo, em uma mistura de Paris Requintada e Bahia afro-lusobrasileira.

"Di Cavalcanti, Jayme Ovalle e Villa Lobos (o maestro martelava suas composições nos velhosos e fanhosos pianos das pensões francesas) amanheciam a gritar pelas ruas. Foram os pioneiros de uma boemia sempre renovada, sem vícios maiores, que teve como seguidores os jovens tímidos intelectuais vindos da província, e que se prolongaria por vários anos." (DAMATA, 2007: 22)

A boemia literária dos anos 30 sucedeu essa geração, dando continuidade a essa recém-inaugurada vida literária da Lapa. De acordo com Velasques (1994), é essa geração que acabará por consolidar a Lapa como bairro boêmio. Ainda que falemos em uma geração de 30, não havia uma homogeneidade na constituição da boemia lapiana, que se subdividia em diversos grupos. A turma do Luís Martins ${ }^{9}$ era composta por Odylo Costa, João Lyra, Raimundo Magalhães Júnior, Joaquim Ribeiro, Jorge Amado, Peregrino Júnior, Murilo Miranda, Tomás Santa Rosa,

\footnotetext{
${ }^{9}$ Uma das figuras de destaque da vida boêmio-literária da velha Lapa.
} 
Moacir Werneck de Castro, Francisco de Assis Barbosa, Henrique Pongetti, Carlos Lacerda, Rubem Braga, Augusto Rodrigues, Rosário Fusco, Genolino Amado, Alvarus, Dante $\operatorname{Costa}^{10}$, Amadeu Amaral Júnior, Martins Castelo, Deocleciano Martins de Oliveira, entre tantos outros que dividiam as poesias, as mesas de bar e as incursões pelo mundo lapiano.

Eram várias turmas na Lapa dos anos 1930. Octavio de Faria, Lucio Cardoso e Vinícius de Moraes, por exemplo, formavam um grupo à parte, contemporâneo do grupo de Luís, mas só se acenavam à distância. Manuel Bandeira, que se dava com todos, descera em 1933 da rua do Curvelo, em Santa Teresa, para a rua Morais e Vale. Donde era morador da Lapa - e logo onde -, mas cioso de sua tuberculose não circulava na boemia (segundo amigos, às vezes visitava de tarde uma "casa suspeitíssima" na rua do Riachuelo). Portinari morava num sobrado na esquina Joaquim Silva com Teotônio Regadas, mas também não aderira à esbórnia. Havia turma da "esquerda": Osório Borba, Barreto Leite, Francisco Mangabeira, Octavio Malta. E a turma do samba: Silvio Caldas, Aracy de Almeida, Nássara, Mario Lago, Bororó, Wilson Batista, Roberto Martins, Geraldo Pereira. (CASTRO, 2004:19)

Luís Martins, em seu livro Noturno da Lapa, nos traça um excelente retrato da boemia Lapiana dos anos 30. Jovens que fizeram da Lapa seu refúgio e elegeram-na como símbolo de suas vidas devotadas à noite, à diversão e à literatura. Uma juventude que "transpirava o ácido veneno da literatura" (MARTINS, 1979: 26) e conhecia os versos dolorosos de Apollinaire. A Lapa de Luís Martins era da poesia e da literatura, os boêmios saíam pelos bares recitando Villon, Verlaine ou Baudelaire.

Tantos os bijoux como, frequentemente, a própria três-che-re, devem ser tomadas menos como realidades palpáveis (o dinheiro era escasso), do que como sugestivas e embriagadoras iluminações verbais, favorecidas pela confusão do local inconfessável e a magia da hora avançada, propícios ambos a essas licenças poéticas, que brotavam, como estranhas flores de absinto e de retórica, nos prosaicos copos de cerveja largamente consumida en ce bordeau aù tenons notre état. Sabíamos a praticávamos também o nosso Villon. (MARTINS, 1979: 26)

\footnotetext{
10 Sobre a presença de Dante Costa na Lapa, Luís Martins afirma: "Dante costa foi, para mim, durante muitos anos, um companheiro dos mais íntimos e certamente dos mais queridos. Nós éramos quase inseparáveis (...) Mas - curioso! - apesar de saber que andávamos sempre juntos, não consigo lembrar-me com precisão de sua presença na Lapa”. (MARTINS, 1979: 46)
} 
Um elemento extremante importante para a ambiência do fenômeno da boemia era o que a Lapa noturna podia oferecer. “- À noite, era difícil conseguir cadeira num café. O largo, quase intransitável fervilhava. Os cabarés, cheios. O vozerio era ouvido à distância todo mundo bebendo e cantando, feliz. Uma beleza!" 11.

"Na Lapa, o que havia eram cabarés." (Martins, 1979: 108). Os cabarés mais frequentados, recorda Damata (2007), eram o Apolo, o Royal Pigalle, o Rex, o Tabu e o Brasil. Segundo o autor "esses cabarés tinham frequência cosmopolita, as mulheres eram selecionadas, cheias de jóias escolhidas a dedo. Pequenas distintas "pensionistas" das melhores casas da Joaquim Silva". Um símbolo de prosperidade, requinte e caracterização da ostentação que se perseguia eram as dançarinas dos cabarés que, segundo Gruman (2012), animavam a vida noturna e ditavam a moda "francesa" ao desfilarem com trajes caríssimos e cobertas de jóias, dadas por seus protetores. Apesar do glamour e experiência franceses que esses locais proporcionavam aos seus visitantes, Martins (1979) afirma que esse foi o aspecto que menos deixou saudades no grupo boêmio que ele frequentava, segundo o próprio, eles não eram freqüentadores assíduos de cabarés.

Já os bares eram muito frequentados pela boemia. Nesses locais, discutiase literatura e a boemia ancorava, estabelecendo os mais variados tipos de relações. O Siri, tal bar recebia esse nome pelos famosos siris preparados pela francesa Raymonde, também conhecido como "49”, o Café Colosso, o Capela, o Café Bahia, o Túnel, o Gruta do Frade, o Túnel da Lapa, o Danúbio Azul e o Arraial, eram os locais de parada obrigatória dos boêmios. Grande parte dos encontros boêmios era realizada nesses locais.

Esse bar (Túnel da Lapa), depois de ampliado, provido de restaurante, músicos e garçonetes, iria ser um dos cenários prediletos das nossas noitadas na lapa. Digo "nossas" referindo-me aos companheiros daquele tempo, alguns dos quais a estreita convivência daquelas noites de boemia e exaltação lírica iria transformar em amigos fraternais, dos melhores, dos mais leais, dos mais queridos que tive a felicidade de conservar até hoje, através do tempo passado e tanta vida vivida! (MARTINS, 1979:42)

Odylo, Márcio, Kauffman, Deoclesiano, Cartens e eu acabamos optando pelo "Túnel da Lapa"; ocupamos uma das mesas (...) Em outra mesa, mais para os fundos, vemos pessoas conhecidas: Murilo Miranda, Moacir

11 Damata (2007: 24) atribui essa fala ao escritor Brito Broca. 
Werneck de Castro e Lúcio Rangel. São meus amigos. Dizem-me que estão de saída, já pediram a conta:

- Vamos para o "Danúbio"; o Carlos e o Rubem estão lá, com o Newton Freitas.

Trata-se de Carlos Lacerda e Rubem Braga. (...)

Entra um grupo de jornalistas e intelectuais muito politizados, com os quais pouco me dou: Barreto Leite, Francisco Mangabeira, Otávio Malta, Osório Borba.. (...) Bem lá para o fundo diviso outros conhecidos: Santa Rosa, Waldemar Cavalcanti, Simeão Leal, Alberto Passos, Guimarães, vou com eles; dizem-me que estão esperando Jorge Amado, que ficou de vir. (...)

De repente, tenho uma idéia:

- Vamos até o "Danúbio Azul". Lá estão o Carlos Lacerda, o Rubem Braga e aquela turminha que saiu daqui... A gente confraterniza. (MARTINS, 1979:70)

As longas conversas com Teodemiro Tostes, no bar “49" versavam quase sempre sobre literatura. A ele e a Álvaro Moreyra, devo os meus primeiros conhecimentos do simbolismo francês, levando-me a estudá-lo com entusiasmo. (...) Teodomiro era uma apaixonado por poesia de Mallarmé, Rimbaud, Verlaine e Laforgue. E, por causa de Laforgue, travou certa noite, com R. Magalhães Júnior, estando eu presente e tentando em vão apaziguar os ânimos, violentíssima discussão, que por pouco não chegou às vias de fato. (MARTINS, 1079: 58)

A boemia afastava-se dessa atmosfera francesa que muitos homens importantes buscavam nos cabarés, na presença de dançarinas ou em bordeis. $\mathrm{O}$ discurso boêmio, como veremos adiante, a todo momento busca afirmar que não participava desses lugares destinados ao vício. Os boêmios constroem uma imagem de boemia sadia, incorruptível e imaculada. Na Lapa, a boemia, segundo os próprios boêmios, frequenta bares, discute literatura e apenas contempla o vício, no entanto a prostituição é um tema recorrente nas narrativas memorialísticas dos boêmios.

\subsection{2.}

\section{Eu queria ser francesa: a prostituição na Lapa}

A nova configuração das urbes, segundo Gruman (2012), possibilitou o passeio pelas ruas e avenidas, bem como a apreciação das vitrines dos magazines, com seus artigos de luxo, importados da França. Havia uma forte apologia ao 
refinamento, o que era expresso na elegância das lojas da Rua do Ouvidor, no centro do Rio de Janeiro, nos automóveis em circulação na Avenida Central, na indumentária dos homens e mulheres das classes mais abastadas e, sobretudo, na adoção da língua francesa como signo de requinte e modernidade.

A prosperidade era visível pela quantidade de produtos de luxo importados e pelo uso de vestimenta européia por parte da classe média e alta no dia-a-dia. Esta vantagem financeira permitia que uma classe de pessoas privilegiadas viajasse à Europa, onde eram expostas às tendências culturais e sociais a serem imitadas. $O$ francês era a língua estrangeira preferida e Paris, a referência intelectual e da moda, enfim, a fonte cultural de onde todas as idéias brotavam. (GRUMANN, 2012:85)

Um importante documento sobre a vida sócio-cultural brasileira neste início de século era a revista Fon- Fon, que, nas palavras de Zanon (2009: 217) além de retratar a vida sócio-cultural do Brasil, a revista "refletia a visão de mundo da sociedade burguesa do início daquele século e influenciava o comportamento da elite carioca por meio de seus registros", a publicação encarregava-se de oferecer, em primeira mão, as últimas novidades de Paris, o maior centro de elegância do mundo, em matéria de moda.

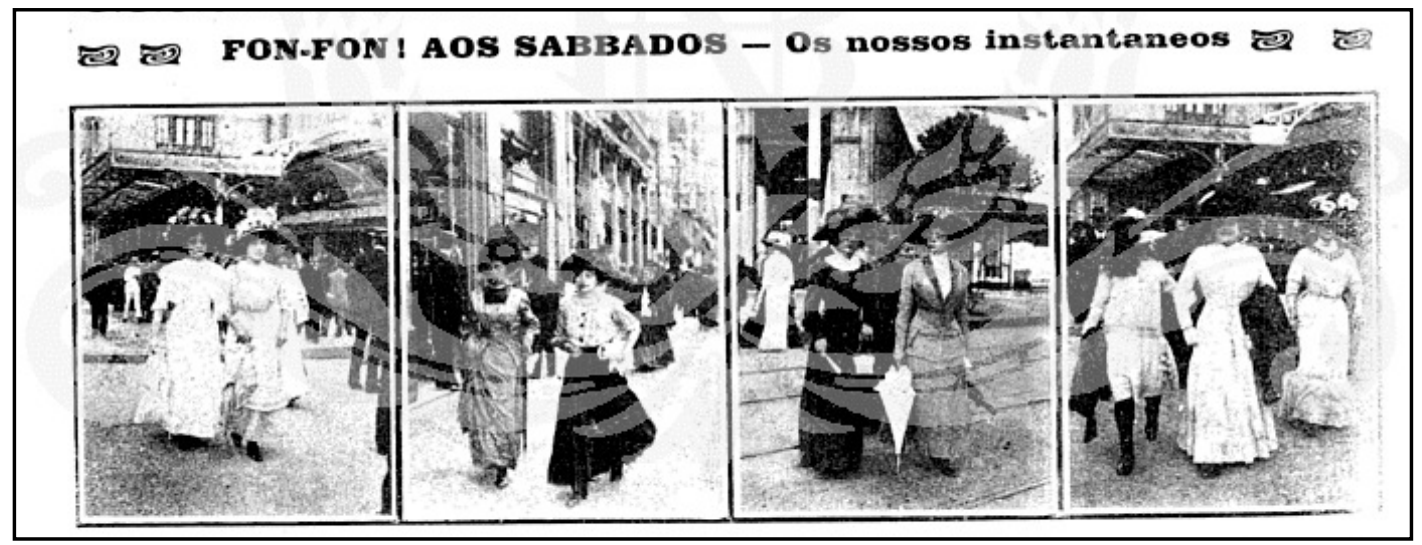

Figura 13 - Revista Fon - Fon, publicada em agosto de 1910 - Disponível em: objdigital.bn.br/acervo_digital/div.../fonfon/fonfon_anos.htm 


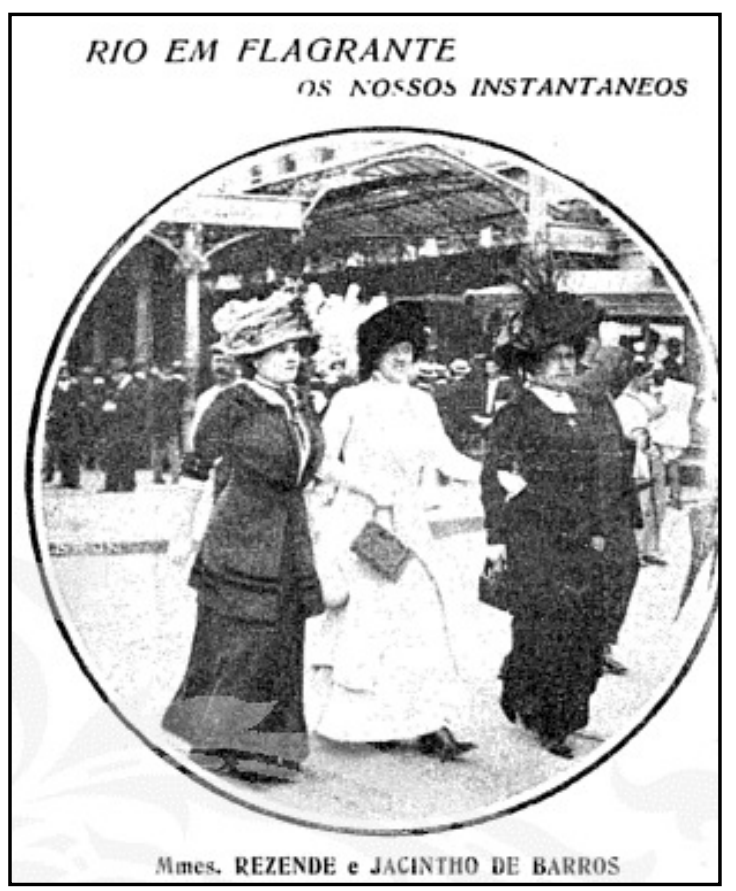

Figura 14 - Revista Fon - Fon , publicada em agosto de 1910 - Disponível em: objdigital.bn.br/acervo_digital/div.../fonfon/fonfon anos.htm

Podemos perceber, por meio das Figuras 7 e 8, pertencentes à publicação, que a vestimenta utilizada à época em nada condizia com as condições climáticas do Brasil. Procurava-se reproduzir aqui a moda parisiense.

(...) diante do prestígio da França, então no apogeu, a classe dominante brasileira decide transportar para os trópicos o mesmo clima de euforia, civilidade e modernidade da grande metrópole; portanto, não seria de admirar que vivêssemos, vestíssemos e escrevêssemos pelas receitas parisienses. A sugestão de Paris sobre o mundo europeu e ocidental era igualmente bastante poderosa, nessa época, tornando- se, assim, o centro de atração da humanidade, o maior empório de prazer do planeta. (ZANON, 2009: 224).

Nesta busca pela modernidade, pelo requinte e pelo prazer, a prostituição ganha espaço na sociedade brasileira, uma vez que se configurava como porta de entrada para a sociedade civilizada. Cabia, ao meretrício de luxo, introduzir os jovens nas "artes do amor" e ensinar códigos mais modernos de civilidade aos rudes fazendeiros e demais provincianos. Surge a figura da "francesa" ocupante 
de um lugar de destaque na hierarquia da prostituição. O status da cocote circunscrevia-se ao fenômeno da Belle Époque. A grande cocote era presença obrigatória nas estréias de espetáculos, frequentava as altas rodas ao lado de seus amantes e protetores. Modernidade e prostituição se encontravam atreladas, numa época em que muitas das camadas mais abastadas se esforçavam para criarem uma identificação com uma sociedade que fazia uma tentativa expressa em se sintonizar nos desdobramentos do ritmo da economia e da cultura europeias. (SEVCENKO, 2003).

Ser iniciado pelas mãos de uma francesa, nas palavras de Menezes (1992: 27), "tornou-se símbolo de modernidade e de refinamento dos costumes".

\begin{abstract}
A indústria do prazer para os ricos era simbolizada pela figura da cortesã "francesa" e pelo consumo de champanhe. Estas prostitutas gozavam de um nível de vida elevado por conta dos presentes recebidos (roupas e jóias) e do preço que cobravam pelos serviços prestados. O rico empresário ou o político influente, ao consumir o corpo da meretriz "francesa", consumia, sobretudo, um estilo de vida considerado moderno e civilizado. (MENEZES, 1992:27)
\end{abstract}

Mas nem só de "cocotes""12 era composta a prostituição, o meretrício carioca era dividido, de acordo com Matos e Ribeiro (1995), hierarquicamente em três ordens: as de primeira (as "francesas") eram constituídas basicamente por estrangeiras e umas poucas fluminenses, tinham como principais clientes os homens da aristocracia cafeeira e os de nobreza nacional; as de segunda ordem compunham-se de negras e portuguesas; e as prostitutas de terceira ordem, as "rameiras", eram consideradas as de mais baixa categoria porque viviam em casebres insalubres e tinham por hábito se entregar a qualquer um.

A hierarquização nas artes do amor podia ser vista na organização do território $^{13}$. As prostitutas de ordens diferentes não coabitavam, e estabeleciam, na

12 Cocote era o termo utilizado para se referir às francesas. "quem dizia cocote, queria dizer, principalmente, francesa." (MARTINS, 1979: 29)

${ }^{13}$ Souza (2012: 77-86.) define território como um espaço delimitado por relações de poder. Para o autor, territórios existem e são construídos (e desconstruídos) nas mais diversas escalas, tais escalas podem ser (uma rua ou um território nacional) e temporais (séculos, décadas, anos, meses ou dias), em um caráter permanente, mas também em uma existência periódica, cíclica. $\mathrm{O}$ território é "um campo de forças, uma teia ou rede de relações sociais que, a par de sua complexidade interna, define, ao mesmo tempo, um limite, uma alteridade: a diferença entre "nós" 
cidade, uma territorialidade, demarcando os locais de ambiência do exercício de suas atividades. Isto ocorria porque, segundo Soja (1993: 183) a função da territorialidade é "segregar e compartimentalizar a interação humana, controlando a presença/ausência e a inclusão/ exclusão de determinados grupos." A demarcação das fronteiras invisíveis nos espaços públicos, para Matos e Ribeiro, ocorre de forma simbólica, combinando uma direção no espaço e a legitimação de sua posse.

Parte da Lapa e trechos das ruas do Riachuelo, Mem de Sá e Frei Caneca, de acordo com Matos e Ribeiro (1995), formavam território conhecido pela prática da prostituição desde o final do século XIX, mas segundo Damata (2007), tal prática adentrou as ruas e travessa internas da Lapa, efetivamente, a partir de 1915.

(...) as ruas - Conde de Laje, Taylor, Joaquim Silva, bem como o decantado Beco das Carmelitas - começaram a infestar-se de casas suspeitas. Nascia então uma nova Lapa: de crimes passionais, de boemia desenfreada, de malandragem, de desordeiros perigosos e de prostituição em larga escala. Mas era também a Lapa dos cabarés e cassinos famosos - O Beira mar, o Assírio, centro da vida noturna da capital, freqüentados pelo mundo elegante, por famílias mais progressistas. (DAMATA, 2007: 22)

No livro Adeus Lapa, Hernani do Irajá revela que as maiores noitadas da Lapa e adjacências tinham lugar em três pontos principais, e isso ocorria não só pela excelência dos ambientes, conforto e seleção da frequência, mas, principalmente pelas belas mulheres vindas da Europa. "Eram elas quase que na sua totalidade francesas de Marselha, do Havre, de Lyon, a maioria era ou dizia-se de Paris. Seria o máximo: uma parisiense!” (IRAJÁ, 1967: 23).

Mas nem todas as francesas do Beco das Carmelitas, nos adverte Martins, eram francesas de fato, mas tão grande era o prestígio e a sedução do título, que todas se diziam compatriotas de Marion Delorme ${ }^{14}$ e Ninon de Lanclos ${ }^{15}$.

(o grupo, os membros da coletividade ou "comunidade, os insiders) e os "outros" (os de fora, os estranhos, os outsiders)."

${ }^{14}$ Cortesã francesa conhecida por seus relacionamentos com os homens importantes de seu tempo. Vários autores dedicaram suas linhas a ela, dentre eles Victor Hugo.

15 Cortesã, escritora e patrona de artes. Culta, amante das letras. 
(Martins, 1979: 29). As francesas eram importadas em grande escala, eram mulheres bonitas e inteligentes. Lúcio Rangel, na crônica A lapa e a música popular, dizia conhecer um vereador que aprendeu francês no meretrício carioca e que sempre voltava para casa, depois de uma noite na Lapa, contando as últimas novidades literárias vindas de Paris. As francesas sabiam aliar "os prazeres da carne aos do espírito" ${ }^{16}$.

A glamourização da prostituição encontra seu contraponto no baixo meretrício, o Mangue, que de acordo com Gomes ${ }^{17}$, teve parte de suas ruas transversais destinadas, desde os fins do século XIX, ao confinamento de prostitutas das classes mais baixas.

Iniciava-se o controle da prostituição e sua regulamentação por parte do Estado, na tentativa de restringi-la a áreas designadas à prostituição tolerada. Em 1920, a polícia foi encarregada de "limpar" a cidade para a visita dos reis da Bélgica: as prostitutas foram presas por vadiagem e depois alojadas em bordéis em nove ruas transversais do Mangue. Constituiu-se, então, um sistema não oficial pelo qual a polícia registrava os trabalhos do sexo e intervinha na administração dos bordéis. Fixou-se assim essa zona de baixo meretrício, em contraste com a prostituição de luxo, localizada no bairro da Lapa, com suas casas noturnas, cabarés e cafés, vindo a constituir a "Montmartre tropical", o local da boêmia intelectual da cidade, que teve seu apogeu nos anos 1930. (GOMES. Archivo no prelo)

No entanto até na própria Lapa, à época do seu auge, a prostituição fora erradicada das áreas mais centrais, por ordem da polícia. Luís Martins relata que, na sua época boêmia, a década de 30 ,

(...) o meretrício fora transferido do beco das Carmelitas, da Rua Morais e Vale e do trecho da rua Joaquim Silva, próximo à praia, para as rua Conde de Lage, Taylor e parte alta da Joaquim Silva, da Rua da Lapa para cima; desta última rua desapareceriam as "pensões chics", casas fechadas de categoria mais elevada. As francesas escasseavam, em virtude das medidas restritivas impostas às atividades da traite des blanches. (MARTINS , 1979: 53)

\footnotetext{
${ }^{16}$ In: DAMATA, 2007:80

17 Nota inédita de Renato Cordeiro Gomes para o poema O santeiro do Mangue, em Oswald de Andrade. Obra incompleta (Coord.: Jorge Schwartz). Paris: ALLCA XX/Archivos, no prelo.
} 
Gruman (2012) credita esse deslocamento à expansão e a urbanização da cidade, na qual os espaços de sociabilidade se multiplicam, levando às famílias às ruas, fato que pressiona "a polícia a atuar cada vez mais com maior vigor na moralização dos costumes", tendo-se uma consequente repressão à prática da prostituição. Essa moralização imposta aos que não se enquadram nos valores defendidos pela Igreja e pelo Estado, se tornará uma das causas da decadência da Lapa, com veremos adiante. 


\title{
3. \\ A CONSTRUÇÃO DO IMAGINÁRIO DA LAPA
}

\author{
Villon, Verlaine e Luís \\ Encontraram-se na Lapa. \\ A vida - essa meretriz - tanto beija como escapa. \\ Villon, Verlaine e Luís \\ Entoaram sua canções \\ Com riso, lágrima, uísque \\ E entre tantas emoções \\ Deixaram na noite escura \\ - Villon, Verlaine e Luís - \\ A luz mais terna, mais pura. ${ }^{18}$
}

Quem quiser cante a sua Lapa, Que eu, cá, vou chorar a minha. Lapa, cachaça zurrapa, Muy decadente rainha. ${ }^{19}$

A construção do imaginário da Lapa está irrefutavelmente ligada à figura da boemia literária. Luís Martins (1989:64), em Noturno da Lapa, afirma que o prestígio da Lapa, á época do seu auge, foi em parte promoção do grupo boêmio que por lá pairava. "Nós escrevíamos sobre ela artigos, crônicas e reportagens; criávamos assim a sua tradição, o seu mito e a sua lenda." O autor, no entanto, questiona se essa famosa "poesia noturna da Lapa" e esse mito montmartriano não seriam um equívoco, se a Lapa não existira somente na imaginação deles.

Às vezes eu me pergunto se, no fundo ela não era totalmente nossa; isto é, uma criação subjetiva, uma ficção poética, um estado de espírito, sem nenhum vínculo ou coincidência com a realidade exterior. Ela existia em nós. E nos dia me que dela nos desinteressamos - morreu, deixou de existir. (MARTINS, 1979:154)

\footnotetext{
${ }^{18}$ DRUMMOND, Carlos. L.M. In: DAMATA, Gasparino. Antologia da lapa. $3^{\text {a }}$ edição. rio de Janeiro: desiderata, 2007:10.

${ }^{19}$ Mário Lago - http://www.mariolago.com.brqfrases.php.
} 
Será que poderíamos pensar o imaginário lapiano como um real deformado, uma ilusão, uma fantasia? Antes de realizarmos uma reflexão acerca da construção do imaginário lapiano, detenhamo-nos no conceito de imaginário.

Michel Mafessoli (2001: 75) atenta para o fato de que o imaginário é identificado, tradicionalmente, como oposto ao real, ao verdadeiro, sendo considerado ficcional, algo sem consistência, distante da realidade palpável, tangível. Esse pensamento foi alimentado pela filosofia racionalista que desconsiderava e eliminava toda e qualquer produção imaterial. Sob a ótica do racionalismo, afirma Serbena (2003:3). “o reino do 'espírito' e da 'cultura' são considerados subprodutos do mundo real, seja da sociedade ou dos processos físico-químicos que ocorrem no ser humano.” (SERBENA, 2003:3).

Assim, o pensamento positivista, cientificista e materialista aplicado ao estudo do imaginário tende a considerá-lo como um real deformado. $\mathrm{O}$ imaginário é concebido como epifenômeno do real e se contrapõe, como ilusão ou fantasia, ao conhecimento e ao saber científico. (SERBENA, 2003:3).

No entanto, segundo o Mafessoli (2001), as construções mentais podem ser eficazes em relação ao concreto, pois o real é acionado pela eficácia do imaginário. Para ele, o imaginário é uma força social de ordem espiritual, uma construção mental que se mantém ambígua, perceptível, mas não quantificável. O imaginário é ao mesmo tempo, impalpável e real.

O imaginário mesmo que seja difícil defini-lo, apresenta, claro, um elemento racional, ou razoável, mas também outros parâmetros, como o onírico, o lúdico, a fantasia, o imaginativo, o afetivo, o não - racional, o irracional, os sonhos, enfim as construções mentais potencializadoras das chamadas práticas. (MAFESSOLI, 2001: 77)

Delleuze (1992) considera o imaginário como a indiscernibilidade entre o real e o irreal, um conjunto de troca entre uma imagem real e uma virtual. O imaginário da Lapa seria, desta forma, uma miscelânea entre a Lapa real e a Lapa construída pela experiência, virtual. Serbena (2003: 4) associa a construção do imaginário à estrutura de constituição do mito. Para ele,

os mitos se organizam em conjuntos e variações em torno de um núcleo temático Ele é visto como uma linguagem a ser traduzida, reconstruindo a sua lógica interna através de uma interpretação adequada. Seria constante a maneira como o mito é construído, a sua forma e sua estrutura, mas 
variando os significados. A estrutura básica que constitui o mito pode ser considerada como um modelo de funcionamento do imaginário.

Nas palavras de Araújo e Teixeira (2009:8), o imaginário, essencialmente identificado com o mito, "constitui o primeiro substrato da vida mental, da qual a produção conceptual é apenas um estreitamento”. Durand (2002: 62-63) entende o mito "como um sistema dinâmico de símbolos, arquétipos e esquemas", para ele o mito é um esboço de racionalização, é resultante da combinação entre imagem e símbolo, nessa acepção, os mitos possuem uma importância vital, uma vez que transmitem verdades importantes em narrativas repletas de simbolismo.

A construção do imaginário da Lapa é fruto das projeções de certa comunidade. Apoiados na teoria de Serbena (2003), podemos dizer que a Lapa tornou-se receptora de interesses e aspirações, modelando comportamentos, condutas e visões de mundo partilhadas por pessoas, criando uma comunidade de sentido. O imaginário, de acordo com Mafessoli (2001: 77), é "cimento social", liga e une uma mesma atmosfera. Desta forma, não é possível falar em imaginários individuais, visto que ele sempre ultrapassa o indivíduo, impregna o coletivo, ou, ao menos, parte dele. Cemin (2014: 1) acredita que a participação em um grupo é essencial para a construção do imaginário, ela é a criação que se origina da "efervescência social", da troca e confronto de ideias. "Ou seja, virtualidades que se intercruzam, se juntam e se repelem em constante movimento de construção de mundos de sentidos capazes de instituir realidades antes inimagináveis".

De acordo com Araújo e Teixeira (2009:10), o imaginário é composto por imagens como representação de "outra coisa", no entanto "não se desenvolve em torno de imagens livres, mas impõe-lhes uma lógica, uma estruturação" que o faz pertencer ao "mundo" de representações. Já para Castoriaidis (1982:48), o imaginário "não é imagem de. É criação incessante e essencialmente indeterminada (social-história e psíquica) de figuras/formas/imagem, a partir das quais somente é possível falar-se de 'alguma coisa'. Aquilo que denominamos 'realidade' e 'racionalidade' são seus produtos". A função imaginária é estabelecida por uma capacidade simbólica, por um vínculo permanente entre a realidade das coisas e sua representação. O imaginário é, pois, o real transmutado em algo que ele não é. 
Consideremos, então, o imaginário como um sistema ou universo complexo e interativo que, segundo Barros (2007:3), abrange a produção e a circulação de imagens visuais, mentais e verbais, atuando na construção de representações diversas e incorporando sistemas simbólicos diversificados. De acordo com a definição dada pelo autor, existe uma interface possível do Imaginário não apenas com o campo das "representações", mas também com o âmbito dos "símbolos". Para ele, é possível falar em simbólico, quando um objeto, uma imagem ou uma representação são remetidos a uma dada realidade, ideia ou sistema de valores que se quer tornar presente. Uma imagem, portanto, pode ser revestida de significado simbólico.

Tal definição nos permite pensar que ao representar uma sociedade, ou, como no caso deste trabalho, um território, estamos sempre nos referindo a símbolos. Ao "construir" a Lapa, evocamos imagens e representações mentais que não são a Lapa, mas que falam por ela, assim, "uma dada realidade é reconstruída pelo imaginário através de seus recursos simbólicos." (SILVA JÚNIOR, 2001:2)

Ao evocar imagens e símbolos para representar um determinado fato social, um grupo estará por sua vez alimentando o imaginário, o que implica dizer que este se expressa por meio de símbolos para reconstruir o mundo real. $\mathrm{O}$ imaginário mantém uma flexibilidade na manipulação das imagens, de tal forma que distorce, (re)cria, metamorfoseia ao representar a realidade. (SILVA JÚNIOR, 2001:3)

No que diz respeito às relações entre o imaginário e o simbólico, é de extrema importância que se leve em consideração que o simbólico sempre remete a um sistema de valores. Visto que os símbolos encontram-se em direta relação com a subjetividade, já que os homens elegem os símbolos com os quais desejam compor o seu imaginário. No que diz respeito aos símbolos que remetem à Lapa, vejamos uma descrição da local realizada pelo Luís Martins:

Não são só o convento e a igreja que dão à Lapa um aspecto monumental e venerável, contrastando com a humildade dos seus velhos sobrados de portas enegrecidas pelo tempo, a pobreza de seu pequeno comércio e os desregramentos de sua vida noturna; um dos seus limites extremos, que a separa das luzes da Cinelândia, é o venerando, o histórico Passeio Público; e é na Lapa que se eleva, desafiando a fúria dos séculos, o grande aqueduto dos Arcos, obra colonial, talvez a mais grandiosa e majestosa das relíquias arquitetônicas do velho Rio. Isto, sem falar na escadaria monumental que sobe para o Curvelo e no pitoresco casario que desce a pino do morro de Santa Tereza sobre a rua Joaquim Silva, fazendo lembrar certos aspectos de Lisboa. As paredes das casas, os 
telhados rústicos, os portais de pedra parecem impregnados do mofo e do tempo; tudo aquilo transpira velhice e tristeza; e, entretanto, a Lapa é - ou era - porque eu me refiro aos anos 30 - um bairro alegre. Pelos menos, movimentado, agitado, cheio de músicas e tabuletas luminosas, indicando bares, restaurantes e cabarés. Na Lapa vivia o Rio noturno. (MARTINS, 1979: 63-64).

Pode-se perceber claramente que a Lapa, neste trecho, é construída de forma subjetiva. Influenciado pela atmosfera local, pelos monumentos, pelo casario, o narrador consegue unir por meio de antíteses duas imagens da Lapa, uma de tristeza e velhice, simbolizada pelo casario, e uma da alegria advinda da experiência nos locais. A Lapa nesta descrição é povoada por imagens, tudo que compõe a Lapa é grandiloquente.

A constituição do imaginário é atravessada também pela dimensão geográfica, e como tratamos de um território- a Lapa - tal dimensão não pode ser posta em segundo plano, “já que é sobre uma base física que se dão as relações sociais onde a história da humanidade se desenvolve." (SILVA JÚNIOR, 2001:3). Castro (1997:178) considera que "todo imaginário social é também um imaginário geográfico, porque, embora fruto de um atributo humano - a imaginação - é alimentado pelos atributos espaciais não havendo como dissociá-los." A relação indivíduo ambiente é extremamente profícua à construção do imaginário. $\mathrm{O}$ espaço urbano configura-se, dessa forma, como:

uma entidade unitária porquanto uma imagem instituída pelo imaginário social, um espaço interno e psíquico, de força simbólica para cada indivíduo ligada ao tempo da sua história e da sua memória afetiva, ou coletiva. No espaço urbano os simbolismos alicerçam uma sensação de integração comunitária e entendimento de qual é o seu lugar na organização social. O espaço se encarrega, pois, de dialogar com o indivíduo e estabelecer as correlações de lugar de acordo com os elementos que configuram linguagem e escrita urbanas. Ou seja, acaba por imprimir e expressar um sentido para estes. (CHALHUB JÚNIOR , 2010: 4)

Os lugares são carregados de simbologias e afetividades. A Lapa possuía territorialidades distintas, sendo assim, cada indivíduo poderia construir um tipo de imagem, de acordo com a experiência humana advinda das diferentes demarcações territoriais experimentadas. As ruas, a igreja, os bares, os bordeis, os cabarés, ou todo e qualquer território demarcado, ofereciam vivências capazes projetar imagens que na mente dos homens se delineavam de diferentes formas, 
produzindo significados diversos. Cada território se configurava, pois, como espaço carregado de simbolismos, sendo capaz de despertar nos indivíduos uma memória afetiva, construtora de imagens.

No entanto, cabe ressaltar, em sintonia com Mafessoli (2001: 76), que "não é a imagem que produz o imaginário, mas o contrário". A existência de um conjunto de imagens é determinada pela existência de um imaginário, a imagem é um produto do imaginário, ela não é um suporte, mas o resultado. As imagens que nos remetem à Lapa são produtos do imaginário que se construiu sobre o local. Parafraseando Mafessoli ${ }^{20}$, o imaginário da Lapa faz a Lapa ser o que é. Barros (2007:26) considera o imaginário uma realidade tão presente como o que poderia ser chamado "vida concreta". "O imaginário mostra-se, dessa forma, uma dimensão tão significativa das sociedades humanas quanto aquilo que corriqueiramente é encarado como a realidade efetiva."

Martins (1989) ressalta que embora os boêmios tenham inventado na Lapa uma artificial e fictícia Pigalle, tenham construído o mito de Montmartre - dada a disposição poética do grupo - o cenário, o ambiente e a atmosfera do local contribuíam muito para essas iluminações imaginativas. A Lapa dos anos 30 existia, certamente na imaginação e na sensibilidade dos boêmios, mas também independente deles, com tua a sua graça, o seu pitoresco e o seu mistério.

Um instrumento imprescindível para entendermos a constituição do imaginário lapiano é a memória, já que por meio dela é possível reconstruir a vivência espacial. A memória possibilita a construção e a reconstituição de experiências concretas. Le Goff (1996: 423) sublinha a memória como a "propriedade de conservar certas informações", para ele a memória remete-nos em primeiro lugar a um conjunto de funções psíquicas, graças às quais o homem pode atualizar impressões ou informações passadas, ou que ele representa como passadas. Nora (1993) acredita que e a memória é construída somente quando o que deve ser lembrado, ou que se quer lembrar, é permeado por significados.

Mesmo um lugar de aparência puramente material, como um depósito de arquivos, só é lugar de memória se a imaginação o investe de aura simbólica. Mesmo um lugar puramente funcional, como um manual de aula, um testamento, uma associação de antigos combatentes, só entra na categoria se for objeto de um ritual. Mesmo um minuto de silêncio, que parece o extremo de uma significação simbólica, é, ao mesmo tempo, um

20 “O imaginário de Paris faz Paris ser o que é.”. (MAFESSOLI, 2001: 76) 
corte material de uma unidade temporal e serve, periodicamente, a um lembrete concentrado de lembrar. (NORA 1993: 21)

O imaginário lapiano foi em parte produzido pelas narrativas boêmias que buscaram eternizar os espaços físicos e sociais vivenciados, lugares de memória investidos de significações e simbolismos. A memória boêmia, a síntese poética que os boêmios imprimiam ao local, selecionou o que da Lapa seria eternizado. Luís Martins (1979) já declarava que as recordações da Lapa não eram as mesmas entre os boêmios, cada qual construiu aquele lugar de acordo com suas experiências. No entanto, segundo Pollak, os elementos constitutivos da memória, seja ela individual ou coletiva são:

em primeiro lugar, (...) os acontecimentos vividos pessoalmente. Em segundo lugar, são os acontecimentos que eu chamaria de "vividos por tabela", ou seja, acontecimentos vividos pelo grupo ou pela coletividade à qual a pessoa se sente pertencer. São acontecimentos dos quais a pessoa nem sempre participou, mas que, no imaginário, tomaram tamanho elevo que, no fim das contas, é quase impossível que ela consiga saber se participou ou não. (POLLAK,1989: 201)

A memória, que na sua essência é fragmentada, é construída em parte pela posse da memória de outrem. Sendo assim, a memória dos boêmios era construída duplamente: pela vivência individual e pela vivência grupal. Os boêmios incorporavam, a seus lugares de memória, acontecimentos vividos pelo grupo ao qual pertenciam. Poderíamos, assim, falar em uma memória boêmia coletiva, extremamente eficaz na construção do imaginário.

\section{1. \\ A Lapa reconstruída pela memória}

O maior volume de produções sobre a Lapa data da década de 60. Apesar de Luís Martins afirmar que o prestígio da Lapa, na década de 30, foi em grande parte produzido pela boemia da época, por meio de crônicas e artigos, tais publicações eram esparsas e nem sempre queriam se referir especificamente ao bairro, somente serviam como pano de fundo para o desenrolar de outras histórias. A Lapa passou a figurar como protagonista quando a boemia literária já não era 
boêmia e o bairro já entrara em decadência (para ilustrar a década de 60, período de extrema decadência do bairro, será utilizado o livro, Lábios que beijei, de Aguinaldo Silva). Nesse momento, as narrativas concentram-se no lugar, buscando resgatar seus tempos áureos. É exatamente isso que as narrativas escolhidas pretendem: imortalizar a Lapa, por meio dos discursos produzidos pela boemia.

Escreve-se para mostrar que, apesar de todas as transformações seguidas, a lembrança dos saudosos e a memória coletiva da cidade sobre a Lapa sobreviviam. E buscando resgatar um período marcante de suas vidas, os autores dessas obras acabam por formular uma visão "positiva do bairro. Nessa perspectiva, é constante a presença de uma evocação ao tempo ideal, balizado pela nostalgia e pela esperança de reviver os velhos tempos. (VELASQUES, 1994:14)

Para os boêmios, a Lapa tornou-se mito, sublimou-se em imagem de paraíso perdido, e escrever sobre o bairro era uma forma de mostrar que a Lapa sobreviveria, a despeito de sua decadência. $O$ destaque de um glorificado tempo de outrora, faz-se importante na tentativa de legitimação e recuperação do lugar.

Alberto Deodato, em Roteiro da Lapa... e outros roteiros, nos brinda com um belo passeio pela cidade do Rio de Janeiro. Desse livro nos interessa a primeira parte "Roteiro da Lapa", na qual o autor nos tece suas memórias de quando ainda morava na Lapa, (viveu oito anos no bairro). Ao passear pelo bairro, ele consegue reconstituí-lo "prédio por prédio, morador por morador, episódio por episódio, a rua toda, do Largo ao Hotel Guanabara”. (DEODATO, 1960:2).

Adeus Lapa, de Hernani do Irajá, é um livro de memórias? Sobre esta pergunta, o autor responde: "sim, e não. Sim, porque repassa vultos e acontecimentos de várias décadas do Rio de Janeiro. Não, porque não teve a intenção de respeitar rigorosamente a cronologia nem recorreu a jornais e revistas ou apontamentos." (IRAJÁ, 1967:8). Segundo o Irajá, o livro é apenas um adeus a um recanto querido. No que diz respeito a não ser um livro de memórias pelos motivos supracitados, há de se discordar do autor. São justamente essas características que tornam esse texto memorialístico. Ele compactua com dois traços da memória: a fragmentação, sendo a memória fragmentada, não há um compromisso com uma ordem cronológica, e a subjetividade, por não recorrer a 
fontes secundárias, $\mathrm{o}$ autor só reconta aquilo que certa forma se tornou significativo para ele, aquilo que se tornou lugar de memória.

Em Noturno da Lapa, Luís Martins realiza uma jornada através de seu passado, reconstruindo a Lapa, por meio das lembranças de sua juventude boêmia. O autor faz uma incursão pelo bairro, revisitando a boemia da época, da qual fazia parte. No entanto, escreve no prefácio da $2^{a}$ edição, que não se trata da história da sua mocidade, mas apenas uma parte dela, a que tem a Lapa como cenário. Por meio desta narrativa boêmia, é possível construir um retrato do que era a Lapa de outrora.

Isabel Lustosa, como ela mesma afirma na apresentação do livro, pretende recuperar a memória da velha Lapa, "a Lapa boêmia impregnada do desencanto do mundo de seus poetas e escritores". (LUSTOSA, 2001:13). Kushnir (2001) ressalta que as escolhas realizadas por Isabel para compor sua antologia, recaem sobre textos que procuraram apreender o bairro em seus vários momentos de decadência e opulência. Lustosa ressalta que a antologia procurou focar "nas mulheres da chamada vida fácil e seus ambientes".

"A literatura que resulta daí tem o sabor amargo que fica na boca da bebida da véspera; tem a morrinha dos quartos das hospedarias de solteiros; tem o cheiro azedo da roupa de cama suja pelo amor de alta rotatividade, e guarda a dolorosa visão da borrada maquiagem da véspera no rosto precocemente envelhecido das mulheres. São as impressões que ficaram na literatura produzida por aquela mocidade perdida que freqüentou, viu e viveu aqueles ambientes." (LUSTOSA, 2001:13).

Já Damata, ao organizar a antologia, deseja guiar o leitor pelas ruas escuras e movimentadas da Lapa mítica e boêmia, que assim "como na Paris dos anos 1920, até a pobreza era charmosa e as prostitutas, francesas”. E segundo o próprio, ninguém melhor do que "seus protagonistas fabulosos" para ciceronear esse passeio.

"Vinicius de Moraes, Manuel Bandeira, Di Cavalcanti, Rubem Braga, Antônio Maria, entre outros, nos levam por esses becos e ruelas onde Madame Satã amava e enfrentava policiais, Villa-Lobos tocava piano nos salões esfumaçados das pensões e Manuel Bandeira escrevia poemas com um olho melancólico na festa que acontecia debaixo de sua janela." (DAMATA, 2007) 
O organizador divide sua antologia em três partes: "A Lapa na crônica ${ }^{21} \mathrm{e}$ no artigo", “A Lapa na poesia” e "A Lapa na ficção'. Será que ao realizar essa distinção o autor deseja conferir à primeira parte do livro, "A Lapa na crônica e no artigo", um status de verdade? Seriam os testemunhos que a compõem irremediavelmente reais? Diferentemente de Damata, Lustosa não realiza nenhum tipo de distinção acerca da natureza dos textos escolhidos para compor a sua antologia. Ser ficcional ou não-ficcional influencia de maneira diversa na construção do imaginário?

Iser (2002) questiona a oposição entre textos ficcionais e não-ficcionais, baseada na oposição fictício/real. Ele afirma que, embora a opinião amplamente aceita de que textos literários são de natureza ficcional, distinguindo-se manifestadamente dos textos que, não possuindo essas características, relacionamse à realidade, a distinção a partir dessa oposição usual é discutível, uma vez que não se pode afirmar que os textos ficcionais estão isentos de realidade, e não ficcionais, de ficções.

Se os textos ficcionais não são de todo isentos de realidade, parece conveniente renunciar a este de relação opositiva como critério orientador para a descrição dos textos ficcionais, pois as medidas de mistura do real com o fictício, neles reconhecíveis, relacionam com frequencia elementos, dados e suposições. (ISER, 2002: 957)

Convém substituir, ainda de acordo o autor supracitado, essa relação dupla, ficção/ realidade, por uma relação tríplice, real/ ficção/ imaginário, visto que "como o texto ficcional, contém elementos do real, sem que se esgote na descrição deste real, então seu componente fictício não tem caráter de uma finalidade em si mesma, mas é, enquanto fingida a preparação de um imaginário." (ISER 2002: 957). A realidade presente no texto ficcional pode ser de ordem social, emocional e sentimental. Não podemos incluir essas realidades no rol das ficções somente pelo fato de estarem inseridas em textos ficcionais, entretanto, não se pode deixar negar que essas realidades ao surgirem no texto ficcional, não se repetem por efeito de si mesmas.

\footnotetext{
${ }^{21}$ Interessante notar que, nesta divisão, Damata retira a crônica do rol de textos ficcionais. No entanto, sabemos que apesar realizar relatos, a crônica pode conter traços ficcionais na sua composição, além de ser composta por meio de um olhar subjetivo, que pode diferir da realidade dos fatos.
} 
Se o texto ficcional se refere à realidade sem se esgotar nesta referência, então a repetição é um ato de fingir, pelo qual aparecem finalidades que não pertencem à realidade repetida. Se o fingir não pode ser deduzido da realidade repetida, nele então surge um imaginário que se relaciona com a realidade retomada pelo texto. Assim o ato de fingir ganha sua força própria, que é de provocar a repetição no texto da realidade vivencial, por esta repetição atribuindo uma configuração ao imaginário, pela qual a realidade repetida se transforma em signo e o imaginário em efeito do que é assim referido. (ISER 2002: 958).

No ato de fingir, o imaginário pode penetrar no mundo e agir, mas ele não é o real, ainda que possa adquirir a aparência de realidade. O que ocorre no ato de fingir é uma transgressão dos limites entre o imaginário e o real, que funciona da seguinte maneira: "na conversão da realidade vivencial repetida em signo de outra coisa, a transgressão de limites manifesta-se como uma forma de irrealização; na conversão do imaginário, que perde seu caráter difuso em favor de uma determinação, sucede uma realização do imaginário.”. (ISER 2002: 958)

O texto literário é uma forma de transgredir os limites entre o real e o fictício, visto que é uma forma determinada de tematização do mundo. No entanto, o ato de criar, não pressupõe a imitação de estruturas de organização ditas reais, mas sim a decomposição de tais estruturas. A seleção do que se vai compor já é uma transgressão de limites, uma vez que ao penetrar no texto já se desvincula dos sistemas aos quais pertenciam previamente.

As narrativas boêmias apresentam-se como atos de fingir e, como tais, somente adquirem aparência de realidade. Até mesmo as, ditas, não-ficcionais, e por esse motivo consideradas reais, não podem ser vistas como verdade absoluta, visto que são frutos da memória, e por este motivo, passíveis de ficcionalizações. A Lapa que figura nesses textos, apesar de ser um lugar real, é descrita enquanto local simbólico, ela nasce das experiências boêmias, e a construção de seu imaginário deve-se em parte aos discursos produzidos pela boemia. Não há grande importância para esse estudo se tais discursos são fictícios ou "reais", mas sim o que eles se propuseram a mitificar desse local.

Alberto Deodato, em "Roteiro da Lapa... e outros roteiros", refaz o mapa sentimental da Lapa, começando pelo Grande Hotel da Lapa, passando pela igreja, 
pelo Machado ${ }^{22}$, pelo Beco das Carmelitas, pela Lapa, 95, uma pensão de estudantes, pelo Passeio Público... Deste último, Deodato faz uma bela descrição.

O Passeio Público na Lapa, todo fechado com grades de ferro, abria seu portão monumental, da rua do Passeio, às primeiras horas. Nada era mais agradável ao estudante das vizinhanças que, manhã cedo, ir estudar naqueles bancos de pedra, à sombra das árvores seculares, junto ao busto dos poetas. E mais: aves em quantidades, gorjeando nas galhas, uma sinfonia, indígena, em pleno coração da cidade. Ao estudante provinciano, a paisagem despertava o afeto da terra nativa. As ramagens espessas. Musgos e liquens. Folhas secas, farfalhantes no chão. O lago límpido, com as "baronesas" abrindo a flor azul. A tranqüilidade. O silêncio. E a água cantante do chafariz de mestre Valentim. Todos os estudantes da Lapa e todos os namorados da Lapa passaram pelo passeio público. (DEODATO, 1960: 20)

A imagem construída por Deodato nesta passagem difere muito do que esperamos ouvir sobre Lapa. A Lapa tornou-se famosa na história da cidade por ser um antro de prostituição, jogatina, cabarés baratos e malandragem. Essa discrepância na construção de imagens sobre o mesmo lugar ocorre pelo fato de o bairro apresentar territorialidades distintas. Essa demarcação territorial ocorria da seguinte forma: levando em consideração a dimensão geográfica atrelada ao uso social $^{23}$, e a dimensão temporal, em uma clara oposição entre a Lapa noturna e a diurna.

Durante o dia, a Lapa se vê como qualquer outro bairro com mulheres trazendo pacotes de mercado, carmelitas indo ao convento, estudantes discutindo Medicina ou Direito no Machado. Mas quando a noite cai, uma completa transformação chega: a Lapa se torna uma festa grande, os convidados vindo de todas as partes, trazendo consigo suas alegrias e tristezas, seus cantos e gritos, seus sambas e poesias (...) Alguns bêbados dormem na mesa; o pianista toca tristemente - a noite já tem começado e as atividades vão seguir até a madrugada, quando a Lapa se fecha até a próxima noite. $^{24}$

Drummond, no excerto acima, descreve brilhantemente essa dupla territorialidade do bairro. À noite a Lapa enfeitava-se acendendo suas luzes,

\footnotetext{
22 "era o nosso cabeleireiro, barneiro, vendedor de livros e casa bancária. Guardava embrulhos e dava recados. (...) O Machado era logo depois do Beco das Carmelitas." (DEODATO, 1960: 10)

${ }^{23}$ Temos como exemplo desse tipo o territorialidade a ocupação das diferentes ruas da Lapa, já citadas anteriormente, pela prostituição.

${ }^{24}$ DRUMMOND, p. 32. In: DAMATA, Gasparino. Antologia da Lapa. $3^{a}$ edição. Rio de Janeiro: Desiderata, 2007.
} 
pronta para a festa. "E pela manhã, saída da noite, cheirando a madrugada", o bairro acorda para a sua vida laboriosa de todo dia. Essa dupla territorialidade temporal também pode ser verificada no livro Adeus Lapa, quando Irajá reconta o episódio do passeio pela Lapa com sua prima Maria Luísa, interna do Colégio Imaculada conceição. A seu convite, a prima fora assistir a um concerto no Instituto nacional de música, na Rua do Passeio. Ao fim do espetáculo, eles percorrem os principais logradouros da Lapa, sem que Luísa perceba. Ao ser indagada sobre ter gostado da tarde, a prima manifesta o desejo de conhecer a Lapa. Ela não tinha se dado conta de que tinha percorrido o tão famoso e famigerado bairro.

Minha prima julgava que na Lapa pudesse observar tudo aquilo que a imaginação cria e exagera, os tipo, as cenas, os dramas, romances ou tragédias divulgados e sempre acrescidos de maiores proporções na imaginação popular.

O que nós vimos, conforme ela mesma lembrou, foi o aspecto normal de qualquer ponto da cidade, na sua vida burguesa, pacata ou agitada, de cada dia. Não aparecera como prejulgava a imaginação de uma menina de colégio de freiras, qualquer aspecto digno de nota, de conduta extravagante ou escandalosa dos que por ali passavam ou viviam.

Talvez ela pudesse satisfazer a ansiedade de seus olhos e lhe fosse concedido acompanhar um grupo dos notívagos boêmios, artistas, poetas, amantes da noite e dos mistérios da lua. (...) É que pela manhã, saída da noite, ainda cheirando a madrugada, a Lapa acorda para a vida cotidiana e pode se ver a vida laboriosa doméstica, de calçada ou de rua. (IRAJÁ, 1967:14)

As diversas territorialidades lapianas propiciavam experiências diversas, e de acordo com as demarcações territoriais e temporais experimentadas, os leitores do espaço eram capazes construir imagens por vezes conflitantes sobre o local. Almeida Fischer ${ }^{25}$, por exemplo, como podemos verificar no trecho a seguir, realiza uma descrição um tanto quanto negativa da Lapa. Descreve o local como velho e feio, "talvez o mais sujo e o mais triste bairro do Rio".

Quartel-general de malandros e vagabundos de toda ordem, ponto de concentração dos segredos da sociedade, dos destinos marginais, a Lapa, com seus sobradões antigos de paredes encardidas, suas ruas mal iluminadas, seus cabarés com ares de mistérios, seus frequentadores de vida suspeita e suas mulheres de rostos borrados como máscaras de

\footnotetext{
${ }^{25}$ FISCHER, Almeida. A Lapa. In: DAMATA, Gasparino. Antologia da Lapa. $3^{\text {a }}$ edição. Rio de Janeiro: Desiderata, 2007. p.67
} 
clown, é um território do vício e do crime plantado no coração da metrópole.

(...) quando a noite desce e as luzes se acendem, são os frequentadores dos bas-fond que surgem vagaraosos, parando pelas esquinas, aboletando-se nos bares de baixa classe. É a população noturna do bairro constituída, em sua maioria, de boêmios, contraventores, criminosos de todos os graus e de um ou outro turista temerário em busca de novidade, de pitoresco.

Freqüentemente há brigas, há roubos, há mortes nas velhas e lúgubres casas de cômodos, nos bares ou nos cabarés(...)

Fischer descreve o bairro como um local perigoso, de insegurança, onde há frequentemente roubos e mortes. Entretanto, Luís Martins afirma não ter visto, durante todos os anos nos quais frequentou o bairro, quase todas as noites, nada que fizesse com a Lapa tivesse essa "lamentável” fama de lugar perigoso, "antro de malandros, bandidos, desordeiros, marginais". Segundo o autor, as brigas, que acontecem em todas as partes, eram muito menos frequentes do que se possa imaginar.

Alguns boêmios parecem lamentar essa fama que o bairro adquiriu. E em suas narrativas procuram mostrar uma Lapa com vícios, já que não se pode negar esse aspecto do bairro, mas capaz de "dar bons frutos à sociedade". Deodato descreve "O Grande Hotel da Lapa" como um centro que abrigava figuras importantes na política nacional. "Tudo quanto foi homem importante no tempo morava naquele hotel.” (DEODATO, 1960:2).

Segundo Damata, (1970:22) a Lapa teve, nessa época, papel de grande importância na vida política nacional. "O destino da nação palpitava no coração da Lapa". O hotel era a residência predileta dos políticos mineiros, que entre mulheres, perfumes parisienses e copos de vinho tramavam o rumo da nação: "foi aí, que nasceu, praticamente, a candidatura de Epitácio Pessoa à Presidência da República, dias após a morte de Rodrigues Alves.” Por lá se podiam encontrar oficiais de alta patente, reformados ou não, desembargadores, ministros, banqueiros, magnatas... A Lapa com suas lindas mulheres, sua graça, seu pitoresco, atraía para si uma elite intelectualizada.

Deodato descreve essa elite intelectualizada. Segundo o autor, poucos nomes ilustres da sua geração não passaram por lá. É este aspecto que pretendemos observar: a forma ele descreve a boemia que habitava a Lapa, 95. Ele 
afirma que o lugar, apesar "de pensão de estudantes pobres", forneceu contingente apreciável à diplomacia.

Não sei onde aprendeu o jeito das boas maneiras. Como decoraram a etiqueta. A mesura. O beija-mão. Porque, daquele convívio acadêmico, nada levaram. Dêsses, freqüentaram a nossa Lapa, 95, Eduardo Silveira Martins Ramos que morreu como embaixador do México; Rui de Castro Pinheiro Guimarães, ministro na Grécia, ao que me parece; Jorge Latour, embaixador no Panamá, e Alencastro Guimarães, embaixador em Roma. Completa o número o meu querido Ribeiro Couto, que está na embaixada da Iugoslávia. (DEADATO, 1960:14)

Ressalta-se, nesta descrição realizada por Deodato, um empenho em demonstrar quantos homens importantes saíram da Lapa. Esta é uma característica que pode ser verificada em outras narrativas boêmias: a construção da imagem de uma boemia que não se corrompeu, mais uma vez demonstrando que a boemia era um divertimento passageiro na vida desses jovens que futuramente iriam repousar na estrutura familiar burguesa. "A boêmia seria, para o bom moço, uma extravagância menor, um divertimento inocente, que não acarreta prejuízo nem representa nenhum perigo para a sociedade do bem.” (BENATTI, 1996:206)

Seigel (1992: 12) já afirmava que a boemia era somente o país da juventude. Segundo o autor, os jovens viviam na boemia porque não podiam - ou ainda não podiam - estabelecer sua cidadania em nenhum outro lugar. Todos os jovens mais talentosos e promissores viviam na boemia, estavam na casa dos vinte anos, não possuíam notoriedade, mas estavam "eventualmente destinados a liderar suas nações como diplomatas... escritores, administradores, soldados, jornalistas, artistas!" Deodato durante todo o seu roteiro sentimental procura sublinhar a vida de estudantes que se tornariam "diplomatas, grandes médicos e notáveis advogados”. Luís Martins, em Noturno da Lapa, também busca reafirmar essa boemia "sadia".

É importante assinalar-se uma coisa: daquele grupo de rapazes boêmios que nós fomos, passando muitas noites nos botequins e cabarés da Lapa, nenhum se perdeu. Quase todos nós casamos, constituímos família, ficamos homens sérios e compenetrados das responsabilidades da vida. Muitos tornaram-se nomes ilustres, respeitáveis e consagrados na literatura, no jornalismo, na política, na diplomacia, na magistratura, na cátedra universitária. Repito: nenhum se perdeu. (GRIFO MEU) (MARTINS, 1979:82) 
E o que seria perder? Seria não se integrar aos modelos consolidados pela sociedade burguesa. No capítulo final do livro, o memorialista retorna a esse pensamento. Ao encerrar suas memórias lapianas, quer deixar registrado que a boemia era um rito de passagem pela mocidade, "éramos apenas jovens", sem nenhum prejuízo ao futuro promissor.

Como já tive a ocasião de assinalar em outro capítulo, daquele grupo de rapazes nenhum se perdeu. Fomos boêmios, sim, por sermos jovens. Muitos excessos praticamos, algumas loucuras fizemos. Mas as nossas almas e os nossos caracteres não se contaminaram, não se macularam, não se deformaram. Permanecemos íntegros e intactos.

Continuamos, pela existência fora, homens de bem, como éramos antes. A maioria casou-se, constitui família. E não sei de um só que, tanto em sua vida privada com pública e profissional, não seja varão exemplar. (MARTINS, 1979:171)

Noturno da Lapa é um livro de saudades, de evocação nostálgica de uma Lapa que o tempo sublimou em uma terna e doce imagem. A Lapa foi uma aventura única na vida dos boêmios. "Foi um instante de graça, de harmonia e de beleza que se realizou através da camaradagem perfeita de um grupo de rapazes, que eram homens de bom caráter, de boa índole e de boa fé" (MARTINS, 1979:171). Apesar de viverem na Lapa, os boêmios fazem questão de reafirmar, em suas memórias, uma distância dos espaços cercados pelo vício e pela perversão.

Esse é o caminho percorrido também por Hernani do Irajá, em Adeus Lapa. Na apresentação do livro, o autor realiza uma sintética descrição da Lapa:

Constituíam o mundo eclético da Lapa, seus bares, seus cafés, suas pensões e conventilhos, seus "rendez-vous", de rameiras disfarçadas em mocinhas de comércio ou colégios... mais ainda: seus bilhares, farmácias, engraxates, vendas açougues, quitandas e cutelarias... Lapa tornava-se mostruário do mundo, como seus vícios e pecados e paixões, com sua virtude, seus encantos e amores, vitrinas de atrações, de ligações efêmeras, de ciúmes e juras de balcão de chope e promessas irrealizáveis, em cinco minutos de cama. (IRAJÁ, 1967:8)

Mas também deixa evidente a sua figura de boêmio "sadio", fazendo questão de esclarecer que não se corrompeu e nem se aventurou nos vícios oferecidos por ela. 
Aos que mais intimamente me conhecem, parecerá estranho eu escrever sôbre a Lapa. Ocorrerá aos outros deduções prováveis, mas errôneas. Nunca fumei, detesto cigarro, jamais joguei, não conheço nada de qualquer dos ditos de azar, de bebidas, só os refrigerantes sem álcool. Mui raras vezes entrei em "cabaret", mais por companheirismo e nunca tive curiosidade de conhecer uma "boite". Nunca houve um beberrão entre nós. Dois apenas enraizavam-se em alguns clubes de jogo. A esses, quando o pano verde os prendia com as garras do vício, nós, os infensos aos carteados ou à roleta, lá os deixávamos e saíamos para outros cenários. (IRAJÁ, 1967:8)

Confrontando os depoimentos desses boêmios, verifica-se certa padronização da memória. Ao construir essa imagem de boemia sadia, imaculada, a boemia afasta-se das margens, sua situação é de passagem, de trânsito, de escape. A Lapa dos cabarés, das prostitutas e dos malandros é para os boêmios um cenário pitoresco e misterioso.

O melhor será dizer que havia duas Lapas: a pública, a evidente, a urbana, com o seu comércio, as suas lojas, os seus restaurantes, os seus bares, os seus cabarés, intensamente iluminada e com um grande trânsito de veículos; e a outra, secreta escondida, suburbana, insinuando-se pelas ruelas escuras na encosta do morro de Santa Tereza - Conde de lage, Taylor, Joaquim Silva. Aí ficavam as "pensões", isto é, os alcouces ou conventilhos, uns pegados aos outros, ocupando toda a extensão da rua (como na Conde de Lage) ou intermitentes disseminados entre casas de comércio, depósitos ou oficinas como acontecia na rua Joaquim Silva (...) Não terei a hipocrisia de dizer que esta Lapa não frequentamos; mas, para os propósitos, fins e caráter deste livro, ela pouco ou nada interessa; nela jamais se firmou e caracterizou aquele espírito de grupo, de sociabilidade, de boemia coletiva, que definia a nossa convivência nos bares.. A eventual excursão por essas paragens sombrias era um ato individual, que em geral, até mesmo devido a um instinto de pudor, se procurava disfarçar ou ocultar dos companheiros. É verdade que uma ou outra rara vez íamos em grupo; mas como Simão diletante de ambientes, à cata do pitoresco... Em geral, nada mais inocente do que essas excursões; a presença de cada um, por uma questão de respeito humano, inibia os demais. (...) $\mathrm{O}$ que quero acentuar e deixar claro é que esse aspecto pecaminoso da Lapa, que a muitos parece predominante, na realidade era, para nós, secundário e acessório. (MARTINS, 1979:144)

Apesar de longa, essa citação é bastante esclarecedora. Ela evidencia a distância entre a boêmia e os outros tipos sociais espalhados pela cidade. Ao boêmio é facultada a contemplação dos tipos humanos. O distanciamento desses 
locais destinados ao vício, "o subúrbio da Lapa"26, não impediu, contudo, que esses boêmios retratassem parte dessa Lapa da qual eles buscavam apartar-se (ou na verdade, diziam apenas fazê-lo?).

As "mulheres de vida fácil" que viviam pelo bairro é tema recorrente nas narrativas boêmias, poucos são os textos que não retratam esse aspecto da Lapa boêmia. A descrição da prostituição no bairro ocorre, nas narrativas, ora fazendo referência à opulência, "mulheres selecionadas, cheias de jóias, escolhidas a dedo" (DAMATA, 2004:24), capazes de aliar os prazeres da carne e espírito, ora como prenúncio da decadência do bairro.

Lúcio Rangel $^{27}$ descreve a Lapa que ele conheceu, ainda na década de 20. Segundo ele, guardadas as devidas proporções, a Lapa em muito lembrava Storyville, de New Orleans. A prostituição era requintada, em contraste com o Mangue, "plebeu e vulgar". A Lapa era um centro de meretrício todo especial. "Para vocês verem o que era a Lapa basta dizer que aqui as moças custavam 20 mil reis, na Zona custavam 5."28. A fama do havia nos domínios da Lapa, "não podia deixar de elevar sempre bem alto as noitadas da conhecida 'connaisseuse' do elemento feminino bem ao paladar dos "gourmets luxuriosos da carne." (IRAJÁ, 1967: 24).

Suzanne, Bonalis, Tinatatti, Sarita, Madoux, Yvonne, Anitta Luna, Erotildes Amorim, Iracy de Lima Guerra, Dolores Quesada, Zulú, Anita Graça, Olga Docel, Dorvalina de Lima, Iracema Barbosa, Erotildes Araújo, Mercedes Ramirez, Josefina Leal, Lolita, Chiquinha Matipó, Laura, Vanda, Rebeca, Aída, Arlete, etc. O bairro abrigava as melhores mulheres. "A mais fina prostituição franco-carioca da época por ali transitou." ${ }^{29}$ Irajá (1967) ilustra seu livro com

\footnotetext{
26 A Lapa não era, como foi o Mangue, uma zona exclusivamente ocupada pelo meretrício. Este era, sem dúvida, um dos seus aspectos, mas é preciso que se esclareça: a sua face oculta, o seu lado secreto, a sua parte reservada e mais ou menos dissimulada em ruas periféricas que poderiam ser consideradas como o "subúrbio" da Lapa. (MARTINS, 1979:143)

27 . RANGEL, Lúcio. A Lapa e a música popular. In: DAMATA, Gasparino. Antologia da Lapa. $3^{\text {a }}$ edição. Rio de Janeiro: Desiderata, 2007. p.80

${ }^{28}$ FERNANDES, Millôr. A Lapa. In: DAMATA, Gasparino. Antologia da Lapa. $3^{\text {a }}$ edição. Rio de Janeiro: Desiderata, 2007. p.10

${ }^{29}$ ANTÔNIO, João. A Lapa acordada para morrer In. LUSTOSA, Isabel. Lapa do desterro e do desvario - Uma antologia/ vários autores. Rio de Janeiro: Casa da Palavra, 2001.
} 
algumas figuras de meretrizes da época, dentre as imagens, encontra-se o retrato de Suzanne (Figura 10), presente tanto no livro do Irajá, quanto no do Deodato ${ }^{30}$.

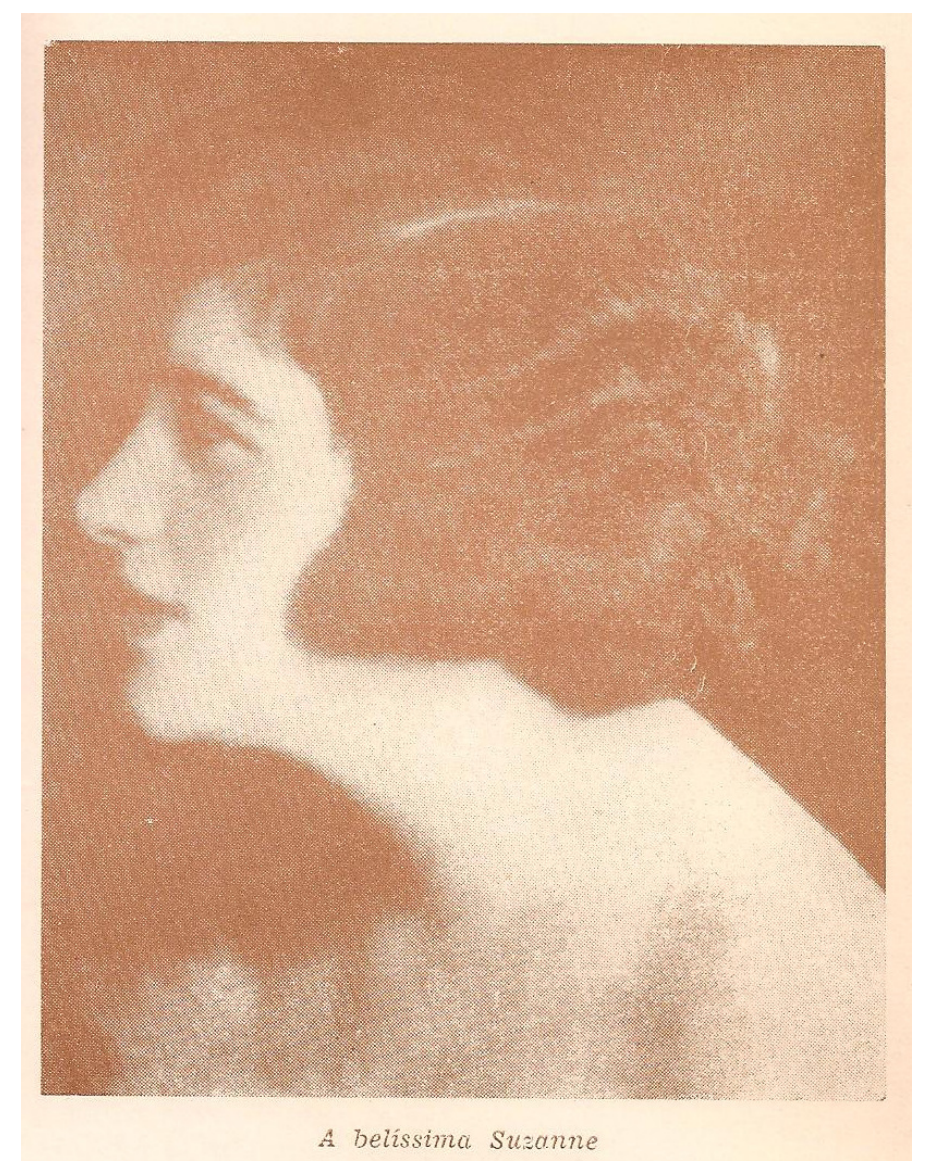

Figura 09 - Imagem da prostituta Suzanne, retirada do livro Adeus Lapa, de Hernani do Irajá. p.97

Irajá a descreve enquanto jovem, ainda praticando o meretrício, rodeada de lindíssimas fêmeas de todas as nacionalidades. Segundo Irajá, Suzanne educava as mulheres para que seduzissem os coronéis a ponto de fazerem-se gamadas, tornando-os, assim, fregueses de presença obrigatória. Já Deodato a descreve na velhice, quando já se tornara Dona Suzana. "Era íntima da grã-finagem do tempo. As grandes pensões alegres eram dela.”.

Enquanto alguns boêmios, ainda que neguem a frequência nesses locais, retratam o meretrício de luxo, com prostitutas refinadas capazes de trazer para a

\footnotetext{
${ }^{30}$ A grafia do nome dessa meretriz difere nas narrativas desses autores. Deodato escreve Suzana Castera, já Irajá, Suzanne Casterat.
} 
Lapa o espírito francês, tão cultuado pelas elites, outros traçam a imagem do desencanto, da decadência.

Nem todas prostitutas tiveram o destino de Suzane, algumas se perderam pela Lapa, morreram com ela, outras migraram para o Mangue. A Lapa era ingrata. As que conseguiram sair da prostituição, por meio de um casamento com um homem importante, procuravam esquecer, ocultar o passado. "Para elas, a velha e pecaminosa Lapa é uma lembrança pouco agradável, uma ferida que ainda não cicatrizou." (DAMATA, 2004:26)

Ribeiro Couto, em Uma noite de Chuva ou Simão, diletante de ambientes, mostra outro lado da prostituição. A opulência cede espaço à decadência. Couto descreve o encontro do narrador-personagem, Simão, com uma ex-babá "num quarto sujo e malcheiroso da Lapa.”. Simão espanta-se diante daquela mulher com o rosto bexigoso e emudece ao lembrar-se da Maricota do seu tempo de criança.

Uma comoção profunda me pungiu. Tive vontade de chorar. Maricota... (...) a Maricota daquele doce tempo, quando eu usava camisola(...) que dormia no meu quarto, junto à minha cama, porque eu tinha medo do invisível e da escuridão. ${ }^{31}$

O narrador descreve seus sentimentos após este encontro, ao revisitar suas lembranças e confrontá-las com o a "nova" vida de Maricota sente asco, nojo e aversão, mas também "mágoa, saudade, pena, revolta...". Ribeiro Couto, despe a prostituição do glamour retratado em outras narrativas.

Essa desglamourização da prostituição também pode ser verificada no livro Lapa, de Luís Martins. O autor, no próprio livro, no que chama de "nota absolutamente necessária", diz que Lapa é uma crônica trágica da prostituição carioca, onde a mulher é uma vítima aniquilada e sem protesto. O personagem principal, Paulo, vaga sozinho por uma Lapa triste e vazia, deparando-se com a verdade nua e crua da prostituição. A primeira imagem do livro é seguinte:

(...) ao passar por perto da mulher, ela me agarrou.

- Que é isso? - perguntei.

- Vamos, entra - respondeu.

\footnotetext{
${ }^{31}$ COUTO, Ribeiro. Uma noite de Chuva ou Simão, diletante de ambientes. In. LUSTOSA, Isabel. Lapa do desterro e do desvario - Uma antologia/ vários autores. Rio de Janeiro: Casa da Palavra, 2001.
} 
Falava em voz baixa, rápida, surda, de comando e de súplica. Não tive bem tempo de raciocinar, fui empurrado por uma porta que se fechou sobre mim. Então, reagi. Na certa, aquela velha estava pensando que eu era trouxa, que ia com ela, com aquela cara! Fui tratando logo de dar o fora. (...) Era a mulher mais estragada do mundo, flácidas, sem dentes, ridícula, com suas rugas maquiadas e com os seus cabelos pintados.(...) Era horrorosa. (MARTINS, 2007:9)

Paulo demonstra nojo por aquela mulher desgastada pelo ofício. Diz-se aterrorizado com o fato de imaginar "aquela carne cansada" em sua carne. Neste momento, saem da cena lapiana as belas e distintas meretrizes para darem lugar às mulheres "vitimadas" pela prostituição. De acordo com Castro (2004: 26), para Luís Martins "Não há vamps entre suas prostitutas, apenas vítimas, inclusive as que caíram "na vida" por vocação."

Martins pretende deixar muito claro que as raízes do Lapa não são literárias, embora tudo, a rigor, situe-se no plano da ficção, "dado que os personagens são puramente imaginários e os fatos descritos meras transposições, deformações ou adaptações da realidade". (MARTINS, 1979:98). No entanto, essa leve mistificação, justiça Martins, não basta para retirar o caráter de documentário e de depoimento baseado na verdade. Para ele, Lapa nada mais é do que uma reportagem.

Martins, em Noturno da Lapa, admite que o Lapa derivou de sua experiência pessoal:

Não preciso dizer que ele deriva de uma experiência pessoal. Como todos os rapazes do meu tempo, eu passei por aquele purgatório do sexo, com a diferença, entretanto, que desde cedo me foi dado ver e sentir o lado doloroso e vil desse torpe comércio, comovendo-me com o ultrajante rebaixamento da condição humana à sua própria caricatura. (MARTINS, 1979:99)

No entanto, o autor contradiz- se:

Os espíritos excessivamente imaginosos que quiserem ver neste livro uma autobiografia, enganam-se redondamente. Minha vida, muito menos interessante do que a do personagem principal, dela difere por completo. Mesmo, talvez, o que possa haver de falso e fraco no livro é a ausência de "experiência": vi tudo de "fora", como um cronista curioso, sentindo o drama como um espectador comovido. ${ }^{32}$

\footnotetext{
32 Esse trecho transcrito acima se encontra na abertura do livro, em uma parte denominada "Nota absolutamente necessária”. (MARTINS, 2004: 35 - 36).
} 
Se antes admite ter conhecido a prostituição, ainda que por pouco tempo, já que "despertou" cedo para o lado "doloroso e vil” desse comércio, depois nega essa experiência. Martins não quer seu nome atrelado a esse lado da Lapa. Deseja deixar bem claro que Paulo é um personagem ficcional, que dessa Lapa não fez parte. Mais uma vez pretende confirmar esse lado de sua boemia "sadia".

Se o lado decadente do meretrício encontra-se na obra, não podemos dizer o mesmo sobre o bairro, a Lapa não está neste livro. Castro (2004:26) na apresentação da $2^{\text {a }}$ edição do livro, atenta para este fato.

Curioso é que, ao escrever um romance que passava ali, o cenário e a história nada tivessem a ver com a euforia que ele experimentava na noite. Lapa, ao contrário, era um romance sombrio e pessimista, com personagens destinadas à dor, à miséria e à morte. (CASTRO, 2004:26)

Manuel Bandeira, depois de ler romance, disse ao Luis que gostara, mas que faltava mencionar a igreja. Ele respondeu que faltava "não só a igreja, como a própria Lapa, a sua atmosfera, o seu ambiente, a sua vida, o seu encanto, o seu mistério". (MARTINS, 1979:100). A Lapa do livro, sublinha Castro (2004), é estranhamente despovoada, o protagonista, Paulo, anda sempre sozinho, só penetra lugares semivazios e quase todos os seus interlocutores são as prostitutas. Não seria esse despovoamento da Lapa uma forma de deixar claro que a experiência da prostituição era sempre solitária e que essa Lapa era sempre vazia e triste, em contraste à Lapa da boemia "sadia"? Os boêmios procuram ocultar em suas memórias a presença nesses lugares destinados ao vício.

De acordo com Velasques (1994), os boêmios reconheciam a fama negativa do bairro, e por este motivo faziam questão de distinguir a sua boemia das demais formas de prazer e divertimento do bairro. Eles descrevem a Lapa em sua plenitude, mas sempre preocupados em enfatizar que não se "macularam", os discursos que eles proferem estão sempre apoiados na moralidade. Benatti (1996:213) atenta para o fato de que os depoimentos memorialísticos dos boêmios, como, aliás, todas as formas de rememoração individual ou coletiva, operam uma seleção dos conteúdos. Nessa seleção, um conjunto de aspectos é eleito como dignos de serem lembrados, podendo e devendo ser rememorado, enquanto outros são simplesmente apagados. A seletividade da memória boêmia elegeu seus totens e seus tabus. Na construção das narrativas boêmias, ficou 
evidente o que da Lapa deveria ser eternizado. $\mathrm{O}$ imaginário que se construiu em torno das figuras femininas, diferentemente do que ocorre com a dita "boemia sadia" é uma imagem que não se pretende resgatar.

\section{2. \\ A decadência da Lapa}

O apogeu da Lapa compreende os anos de 1929 a 1938. "Em 1929 atingiu o fastio e até 38 manteve um fio constante de loucura, reunindo e irmanando músicos populares, políticos, malandros, escritores, artistas, prostitutas (...)” 33 . Os anos 40 assinalam a decadência do bairro. Muitos creditam esse fenômeno ao Estado Novo, à Segunda Guerra Mundial e ao crescimento de Copacabana. No entanto, outros fatores contribuíram fortemente para a decadência do bairro, dentre eles o fato de a própria boemia abandonar a Lapa.

A ascensão de Vargas, de acordo com Rodrigues (2009), em 1930, significou a consagração da polícia, como o principal sustentáculo e alicerce do regime, cabendo-lhe implementar as medidas que permitiriam o florescimento de uma nova era, cuja principal característica seria a moralização dos costumes sociais e políticos. A severa repressão à prostituição incluiu-se entre as ações a serem implementadas com este fim.

Durante o Estado Novo, violentas medidas forma tomadas para coibir o meretrício no bairro. Um tom moralizante vestiu a cidade e os donos de poder desejavam acabar com esse "território de pecado".

O regime getulista fechou-lhe os prostíbulos, numa cruzada moralista executada sob o comando de um coronel de artilharia, o chefe de polícia Alcides Gonçalves Ethegoyen. Promoveu uma caçada aos malandros e prostitutas. Vasculhava pensões, cabarés, clubes, casas de jogos. ${ }^{34}$

\footnotetext{
33 ANTÔNIO, João. A Lapa acordada para morrer. In. LUSTOSA, Isabel. Lapa do desterro e do desvario - Uma antologia/ vários autores. Rio de Janeiro: Casa da Palavra, 2001.

${ }^{34}$ ANDRADE, Moacyr. Salve as aquarelas. In. LUSTOSA, Isabel. Lapa do desterro e do desvario - Uma antologia/ vários autores. Rio de Janeiro: Casa da Palavra, 2001.
} 
A polícia começara a fechar os prostíbulos da Rua Conde de Lage e posteriormente fecharia "todos" os bordeis da Lapa. Quer dizer, quase todos, já que comércio do amor venal ainda era praticado clandestinamente. Grande parte do meretrício fora deslocado para a área do Mangue, que também recebeu duras investidas policiais.

Sobre as medidas restritivas à prostituição, Luís Martins (1979: 148) reproduz um diálogo, com o José, "mulato desempenado e de boa pinta, sempre bem-humorado e muito amável com toda gente, era quase um tipo popular na Lapa. De profissão, motorista de praça.”,

Entrei no veículo e puxei conversa. Perguntei o que achava das recentes medidas policias...

- É, doutor. A cana está dura - lamentou o José, coçando a carapina. Logo depois retificou-se - Quer dizer: está dura pros trouxas.

- Como assim? A polícia não fechou tudo?

O José meteu o pé no breque, diminuiu a marcha, quase parou, voltou-se para trás, com a expressão maliciosa e um rizinho canalha:

- Fechou de arque, doutor. O Senhor quer que eu leve agora mesmo o senhor numa boa casa? (...)

- Agora tem uma coisa: é mais caro. O senhor sabe, o negócio agora é clandestino. Tem que dar muita gruja pros tiras..."

- Quer dizer que continua tudo na mesma?

- Não, na mesma, não Senhor. Agora é diferente. A brincadeira está pra quem tem a grana.

Pode-se perceber neste trecho que a prostituição de luxo passava "despercebida" pela polícia quando isto lhe convinha. Levando em consideração que, grande parte dos clientes, das meretrizes de luxo residentes na Lapa, eram homens importantes, como já citado anteriormente, era natural que a polícia e até mesmo as autoridades fechassem os olhos para algumas casas suspeitas.

Martins (1979) reconhece que as violentas medidas policiais contra o meretrício retiraram da Lapa muito do seu pitoresco e sedução, mas ainda que a prostituição tenha contribuído para a decadência do bairro, ele acredita que o extermínio da "pequena Montmartre improvisada nos trópicos" foi apressado pela guerra. No tempo da guerra, o rio transformou-se numa base de operações da frota norte-americana do atlântico sul. Segundo o autor, os louros marinheiros vinham cheios de dólares, ansiosos por gastá-los numa terra "que era um oásis passageiro em sua rota de aventura, sacrifícios e perigos.”. 
Naturalmente invadiram a Lapa, enchendo de alegria, animação, movimento e cantoria os seus bares e cabarés. Isto, porém descaracterizava, modificava, desfigurava profundamente a fisionomia do bairro; uma Lapa ianquizada era impossível. (MARTINS, 1979: 152).

A Lapa pertencia aos boêmios, não era lugar para turistas. Os marinheiros louros do Tio Sam alteraram profundamente a fisionomia do bairro. O estrangeiro significava uma invasão, que descaracterizava a Lapa, privando-lhe de sua identidade profundamente carioca.

Pongetti, em Noturninho da Lapa ${ }^{35}$, diz que "aqueles gigantes louros, ingênuos e risonhos como crianças deram à Lapa a fisionomia de um bar cosmopolita em Copacabana." Moacyr de Andrade, no trecho a seguir, também descreve essa invasão do bairro por um bando "marinheiros louros com os bolsos a explodir de dólares". Segundo o autor, eles fixaram-se nos bares e nos cabarés, instalando a modernização das vitrolas automáticas, imensas.

A proliferação desses engenhos expulsou as orquestras e pequenos conjuntos que faziam a música ao vivo - violinos, violoncelos e pianos a tocar trechos de óperas, polcas, valsas, tangos, canções ciganas, sonatas, canções parisienses - até nos botequins mais modestos. As francesas e as outras já haviam sido expulsas dos bordéis. ${ }^{36}$

As meretrizes expulsas e a "invasão" americana, que altera a fisionomia do bairro, são fatores fundamentais para a decadência da Lapa. Moacyr Werneck de Castro escreve, em crônica para o Correio Paulistano sob o título de Bilhete do $\operatorname{Rio}^{37}$, a seguinte descrição de uma visita ao bairro:

Fui ontem à Lapa. Isto que outrora não se poderia contar em família assume hoje um ar inocente de visita a museu. (...) Fiz ao longo daquelas ruas uma minuciosa peregrinação lírica. Nada resta do Espírito dos velhos tempos. Nada resta de nada (...) Ainda passeiam belas mulatas com seus bacanos, mas é como se estivessem apenas em trânsito.(...) Espio o cabarés, o Túnel, o Brasil, o Tabaris, o Novo México. Estão todos abarrotados de marinheiros americanos, vermelhos, alegres, que vão

\footnotetext{
${ }^{35}$ IN: MARTINS, Luís. Noturno da Lapa. p. 154

${ }^{36}$ ANDRADE, Moacyr. Salve as aquarelas. In. LUSTOSA, Isabel. Lapa do desterro e do desvario - Uma antologia/ vários autores. Rio de Janeiro: Casa da Palavra, 2001. p. 89

${ }^{37}$ Correio Paulistano, 27 de Outubro de 1944 - Bilhete escrito a Luís martins. In: MARTINS, 1979: 155.
} 
colhendo o mais que podem da convivência de uma meia dúzia de mulheres desalentadoras.(...) As minhas pisadas ecoam depois na Rua Joaquim Silva, deserta e carregada de memórias, como se eu caminhasse pelas aleias de um cemitério. Aqui nestas ruas jaz o "Montmartre carioca" de saudosa memória.

A Lapa moribunda dava seus últimos suspiros. "Em meados de 1940, a Lapa já se reduzira a famílias que só deitavam de pijama e camisola e a algumas profissionais desavisadas, cujos corpos pareciam esfarinhar-se ao ritmo agônico das suas últimas "casas suspeitas'." (CASTRO, 2004:14). A última noite de esplendor do bairro, que relembrou a Lapa dos grandes dias, foi em 1945, quando se comemorou o fim da guerra. Depois disso, a decadência instalou-se no local.

Paralelamente ao processo de decadência desse recanto boêmio, Copacabana atraía para si muitos olhares. Entre os anos 40 e 50, o bairro teve um crescimento demográfico de $74 \%$, passando de 74.133 mil para 129.249 habitantes. Começam a surgir linhas de ônibus para a Zona Norte e os subúrbios, que aumentam as ligações do bairro com outras partes da cidade. ${ }^{38}$

Numa edição de 1948, a revista "Copacabana" observava que "as grandes organizações do Rio de Janeiro" não poderiam mais ficar limitadas ao Centro, já que os moradores da Zona Sul possuíam "mais capacidade aquisitiva, mais senso de progresso e mais realidade de civilização". 39

Com a ascensão do bairro e a consequente expansão do comércio, a vida noturna ficou ainda mais agitada e Copacabana virou símbolo de um Rio moderno e cosmopolita. A boemia deslocou-se para lá. A Lapa viu a cidade darlhe as costas.

Muitos antigos freqüentadores da Lapa escolheram outras paragens, para suas reuniões; criou-se então outro tipo de boemia literária, bem diferente da nossa Lapa, porque dela participavam senhoras. (...) Na terrasse do "Alcázar" viam-se, em certas noites, três ou quatro mesas juntas todas ocupadas por intelectuais, artistas, simpatizantes, muitos em companhia de suas respectivas esposas. (...) Houve uma espécie de êxodo para a Zona Sul. (MARTINS, 1979:134)

\footnotetext{
${ }^{38}$ Leia mais sobre esse assunto em http://acervo.oglobo.globo.com/rio-de-historias/a-princesinhado-mar-cresce-leva-rio-na-direcao-da-zona-sul-8906334\#ixzz2uiV8jSPw (c) 2014.

${ }^{39}$ Idem
} 
Luís Martins lamenta esse êxodo boêmio, para ele, com ascensão de Copacabana, o Rio de Janeiro também entra em decadência: "Copacabana vai aos poucos matando o Rio.”.

Como o Rio tem mudado nestes últimos anos! Pode-se dizer quase que Copacabana vai aos poucos matando o Rio. Porque Copacabana pouco ou nada tem a ver com o Rio. Copacabana é alegre, é luminosa, é turística, cosmopolita, vitaminada, esportiva e incontestavelmente bela. Mas não é o Rio. O Rio é a velha cidade imperial das ruas mal calçadas que aos crepúsculos se iluminavam a bico de gás. São os becos estreitos e sinuosos, com recordações coloniais apontando a cada passo. (...) O Rio é a Lapa. (MARTINS, 1979: 134)

Para os boêmios a Lapa era a tradição que deveria ser perpertuada do Rio de Janeiro, o Rio era a Lapa, mas a Lapa agonizava. Certamente, não foi Copacabana a responsável pela sua morte, porém a "princesinha do mar" contribuiu para seu o sepultamento. "A Lapa ficou fora de mão (...) e Copacabana acolheu os trânsfugas do 'Danúbio azul' e do '49', o eixo da boemia literária deslocava-se da sombra dos velhos Arcos para a orla oceânica". (MARTINS, 1979:152)

Mas ainda que a Lapa não entrasse nesse período decadência, os boêmios desistiriam da Lapa. O casamento, grande inimigo da boemia, finda o ciclo da juventude. A boemia de 30 envelhecera. E esses homens vão repousar na estrutura familiar burguesa. No entanto a intelectualidade boêmia necessitava de encontros e discussões. Surge então uma boemia renovada, com a ilustre presença das digníssimas esposas. A Lapa não era um lugar para abrigar senhoras de respeito. Então, os boêmios desistem da Lapa. Para eles, a Lapa morrera, ficara apenas na lembrança, sublimara-se em imagem de paraíso perdido.

No entanto, tais boêmios desejavam ver a Lapa sempre renovada, para que pudessem, já maduros e respeitosos, olhar para trás, fitar o passado e contemplar o mosaico de saudades. A tradição sempre perpetuada, uma geração passando o bastão para outra.

A nossa geração encerrara seu período de boemia e juventude, mas as outras, que nos sucediam, poderiam continuar e perpetuar a tradição montmartriana da Lapa; isto, entretanto, não aconteceu, porque no Rio não é possível a continuidade, a permanência de coisa nenhuma. (MARTINS, 1979:152)

Em suma a Lapa mudara - e nós também. Rompera-se o vínculo de uma finidade que só pudera existir no momento instransponível, intransferível 
e insubstituível de uma extraordinária e feliz coincidência: a do instante único da nossa juventude com a atmosfera ambiente a ela propícia.

Depois perdemos o compasso, saímos do ritmo e as nossas órbitas se distanciaram. O extraordinário é que a Lapa fosse apenas esta fragilidade, esta precariedade esta coisa transitória, efêmera e fugaz: a nossa mocidade. Pois, sem nós, acabou morreu. ( MARTINS, 1979: 160)

No Rio, um hábito, uma rotina, uma tradição nunca se fixam, ressalta Luís Martins. Sendo assim, a Lapa padece, juntamente com a sua boemia. A Lapa mudara e os boêmios também. E as mudanças da Lapa, são extremamente influenciadas pela modificação de seu território.

Se na década de 40, fisicamente não se modificara muito - "pelo contrário, na aparência, continuava a mesma; as mesmas velhas casas, as mesmas ruas trôpegas, as mesmas calçadas esburacadas, as mesmas árvores empoeiradas; quase os mesmos bares cafés, bares e botequins." (MARTINS, 1979:151) - o que se extinguia era a sua alma, na década de 60 sofreu a sua primeira mutilação. Um projeto governamental para a construção de uma grande avenida que cortasse o Centro de norte a sul, desafogando a antiga Avenida Central, foi responsável por uma grande destruição na Lapa. Grande parte da Lapa foi arrasada, mesmo após o plano ter sido abandonado. Em poucos anos quarteirões inteiros foram arrasados e inúmeros prédios foram demolidos. No que diz respeito à vida noturna, a Lapa, nessa época, constituía um triste espetáculo. (DAMATA, 2004:28).

Na década de 70, iniciaram-se as demolições em massa, "e no final da do Governo Chagas Freitas, reurbanizada, seria inaugurada e entregue ao público a nova Lapa. Ficou irreconhecível: um logradouro como outro qualquer, de subúrbio carioca." (DAMATA, 2004:30).

Foi abaixo, nessa demolição devastante, um bom trecho da Rua Mem de Sá, em cuja esquina funcionava o Café e Bra Indígena de um lado e no outro o Café e Bar Continental. Um pouco adiante, ficava a Leiteria Bol. Da Rua Teixeira de Freitas, com seus casarões fin-de siècle e onde funcionavam a Associação dos Ex-Combatentes do Brasil e um banco de sangue, sobraram duas palmeiras imperiais, centenárias, e o nome da rua (algum vereador não tardará de substituir por outro). Foi abaixo, também, no roldão, o casario compacto triangular, formado pelas ruas Mem de Sá e Visconde de Manguarape, apelidado pelo povo de "ferro de engomar" (...) Nesse trecho, dando vistas para o largo, ficava localizado o tradicional restaurante A Capela, no mais puro estilo art déco, e que reuniu, até cerrar as portas, um grupo de boêmios fiéis à Lapa. (DAMATA, 2004:30). 
As demolições iniciadas, no bairro, na década de 60 e que perduraram até a década seguinte figuram no romance Lábios que beijei, de Aguinaldo Silva. Ele "romanceia sua biográfica passagem pela Lapa" (LUSTOSA, 2004:14. O autor ao rememorar seu passado anda pelas ruas da Lapa e registra os seus últimos suspiros. A Lapa, nesse romance, aparece não somente como cenário, mas também como protagonista. Aguinaldo coloca-se, sobretudo, como um insignificante morador do bairro.

Na época eu tinha 22 anos (...) e fora morar no dito cujo sobrado número 46 da rua Visconde de Maranguape, na Lapa, para testemunhar - como eu costumava dizer, entre orgulhosos e tolo - o fim do bairro. O quarteirão onde eu morava foi derrubado em 1970 para dar lugar a uma avenida. Mas muito antes disso, na verdade poucos dias após a minha mudança para o bairro, eu já sabia que na Lapa, em vez de cronista, eu seria apenas um insignificante morador. (SILVA, 1992: 27)

A degradação e a destruição "modernizadora", pelas quais a Lapa passa, estão presentes nessa obra:

(...) o fim já começara. O cabaré Novo México até já fechara, de suas noites restava apenas o anúncio de neón, agora apagado, e Boi, o leão-dechácara que lá morava e que, à hora de sempre, postava-se à porta, no local que fora seu durante anos. Numa esquina dois sobrados tinham desabado durante as chuvas de 1967, em 1968 caíram mais mais dois, e então - ainda sem que acreditássemos - surgiram os operários com suas marretas, e paredes inteiras eram desmontadas sem que eles se preocupassem em preservar os azulejos portugueses, ou as louças dos banheiros todas made in England, ou os frisos art-nouveau, ou as escadas circulares de ferro importadas da Europa e que, arrancadas sem nenhum zelo, serviriam depois para enriquecer as lojas dos antiquários em bairros mais nobres. (...) Era nossa Lapa que acabava? (SILVA, 1992: 115)

Aguinaldo Silva relaciona intimamente a decadência do bairro à vida de seus habitantes. A prisão de Edmundo Bukovisc, o Alemão, e a do próprio Aguinaldo, por exemplo, acontecem ao mesmo tempo em que a prefeitura do Rio inicia rapidamente e em grandes proporções, por conta de um plano de urbanização, a derrubada da Lapa. Durante os 70 dias em que passou na prisão, conta Aguinaldo, tudo mudara:

(...) grande parte das ruas já fora derrubada, e os tratores e empilhadeiras trabalhavam cada vez mais perto da minha casa, diante da qual a bira de 
Hernández não passava agora de um buraco vazio: era o plano de urbanização que avançava. (SILVA, 1992:107).

O romancista, a princípio não vê nenhum simbolismo nesses acontecimentos, assim como também afirma não ter visto, a princípio ${ }^{40}$, nenhuma simbologia entre a morte da prostituta Twist e a destruição da Lapa. Twist agonizava "enquanto tratores e empilhadeiras destruíam tudo em torno dela." (SILVA, 1992:110).

A prostituta morria simultaneamente à Lapa; e do outro lado da rua, erguia-se inacabada a catedral Metropolitana. Segundo o autor, a Lapa foi sacrificada, mais do que pela "idiotia do urbanismo" pela moral cristã, simbolizada pela catedral, que sitiava a Lapa. Enquanto erguia-se a catedral, destruía-se a Lapa. Os ranços da sociedade patriarcal-burguesa decretaram o fim da Lapa, causaram sua desgraça e sua queda.

De acordo com Rocha (2004), o que parece de fato decretar o fim da Lapa é a modernidade, com suas "transformações rápidas e efêmeras que caracterizam o estilo de vida moderno, burguês, racional, capitalista e individualista". Isso é extremamente paradoxal, visto que foi justamente a modernidade, como já visto no primeiro capítulo, que possibilitou a ascensão desse território.

Esse espaço urbano foi modificado inúmeras vezes, e tais modificações ora contribuíram para formação e legitimação do território boêmio, ora, para sua decadência. A tentativa de destruição da Lapa é o que em influxo contrário vai legitimar seu imaginário. É na decadência que os boêmios procuram revitalizar a memória de paraíso perdido. A Lapa morrendo, começou a viver ávida secreta dos símbolos poéticos, multiplicando-se em muitas Lapas.

A Lapa sofreu inúmeras transformações, em luta desigual contra o progresso. Da Lapa, progressivamente desfigurada, sobraram "de sólido e dando a impressão de eternidade, apenas a Igreja e os Arcos". Como podemos perceber nos postais a seguir:

\footnotetext{
${ }^{40}$ Essa relação entre a sua morte e o fim do bairro onde convivêramos durante vários anos - e a ligação entre esses dois fatos e tudo mais que aconteceu na Lapa durante a última semana em que estive lá - eu só perceberia nãos depois, quando me veio a ideia de escrever este livro. (SILVA, 1992:110).
} 


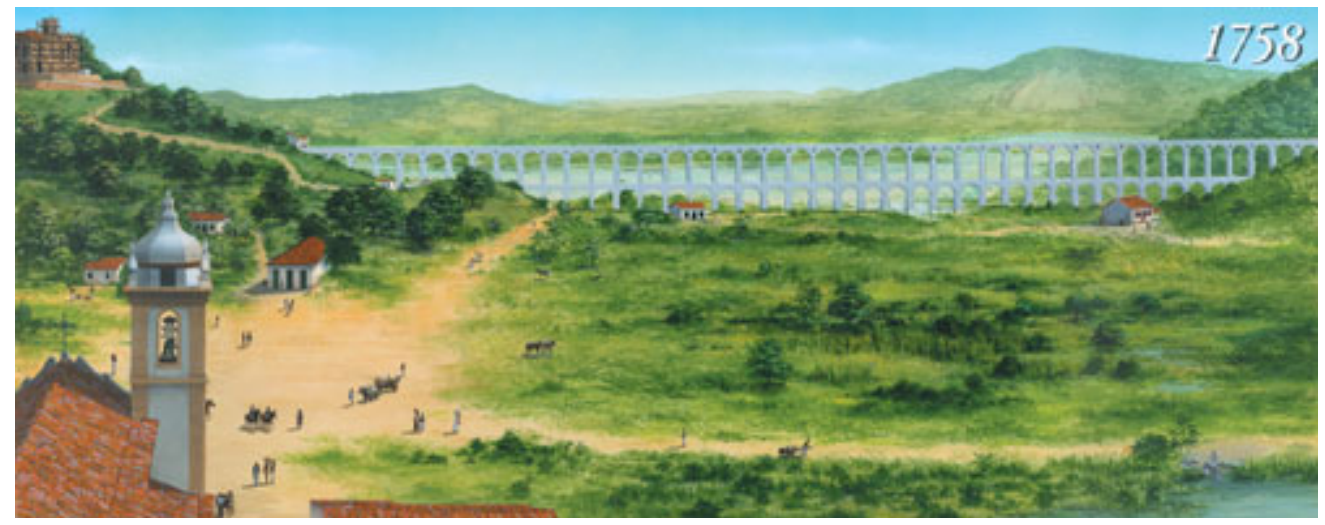

Figura 10

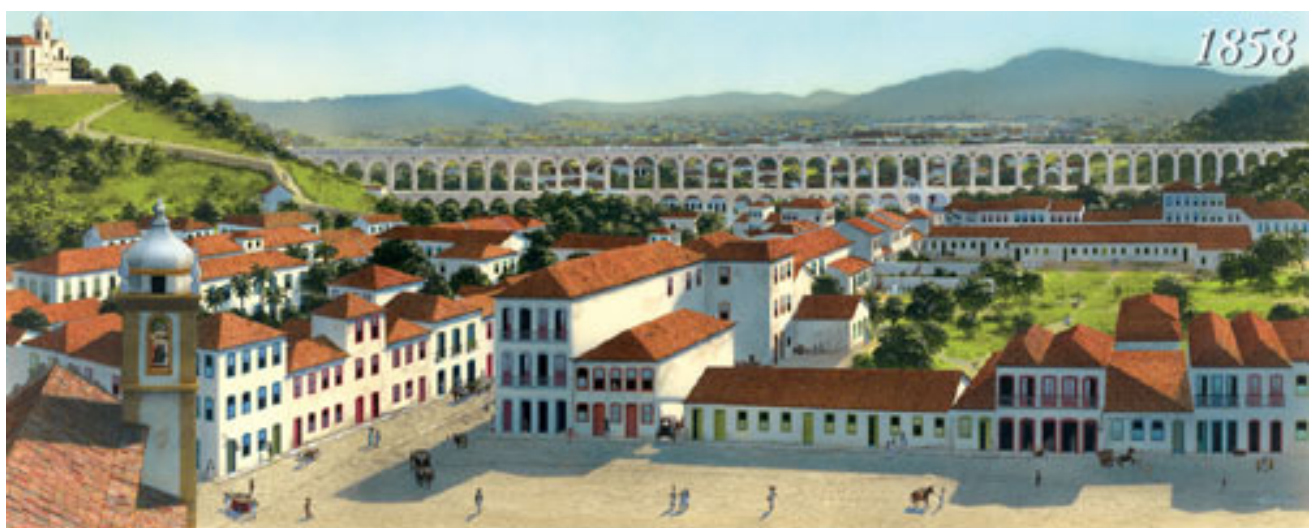

Figura 11

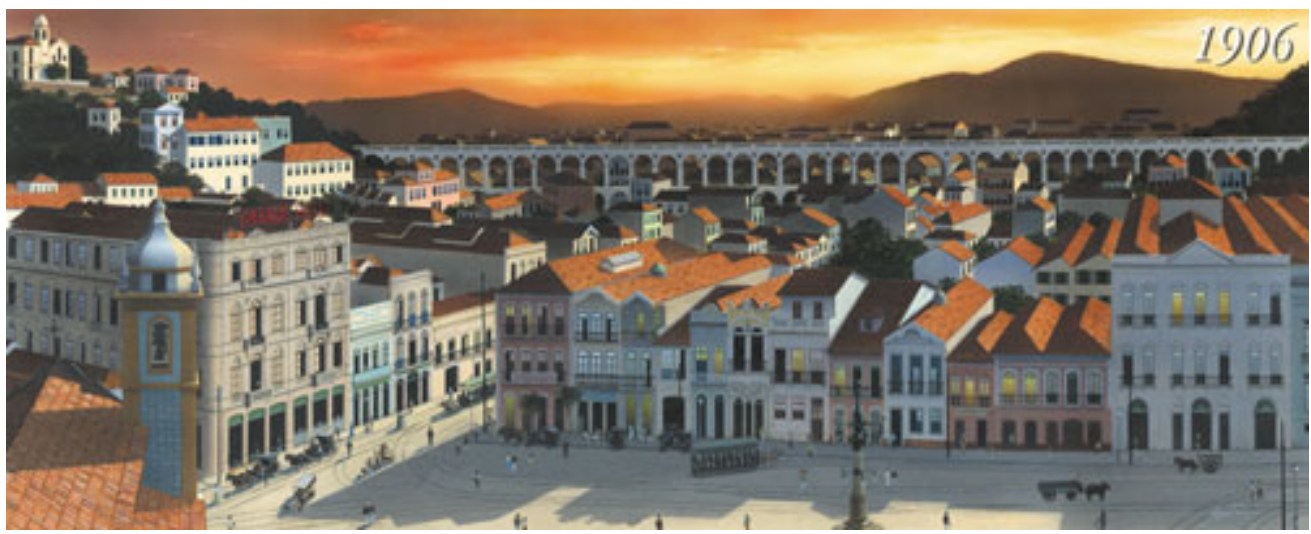

Figura 12 


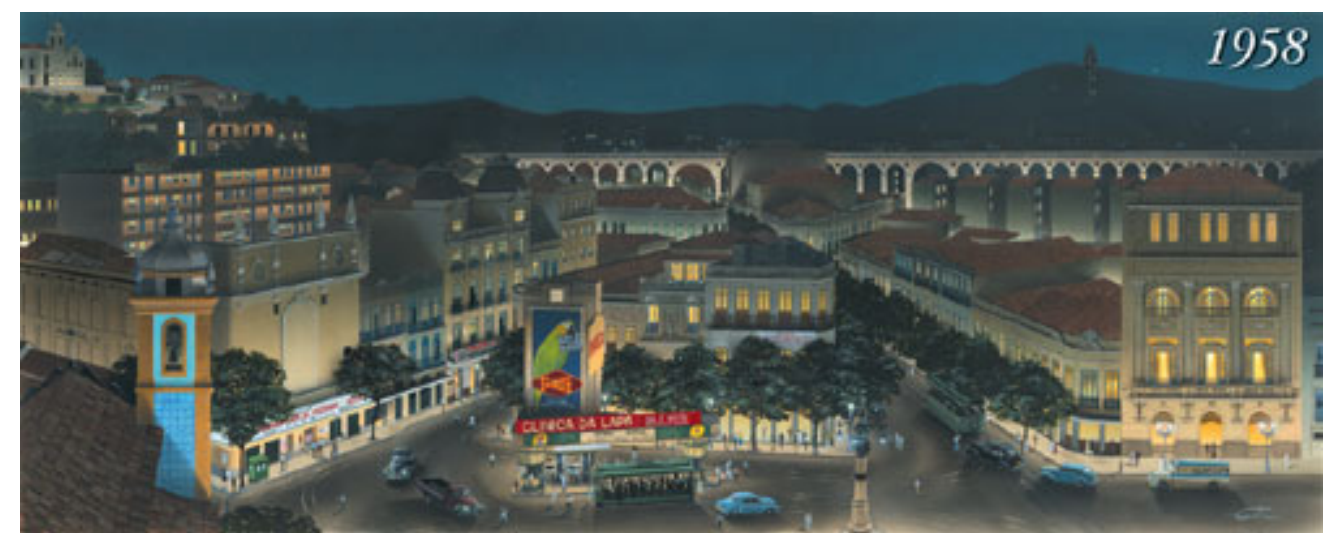

Figura 13

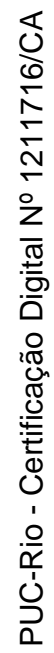

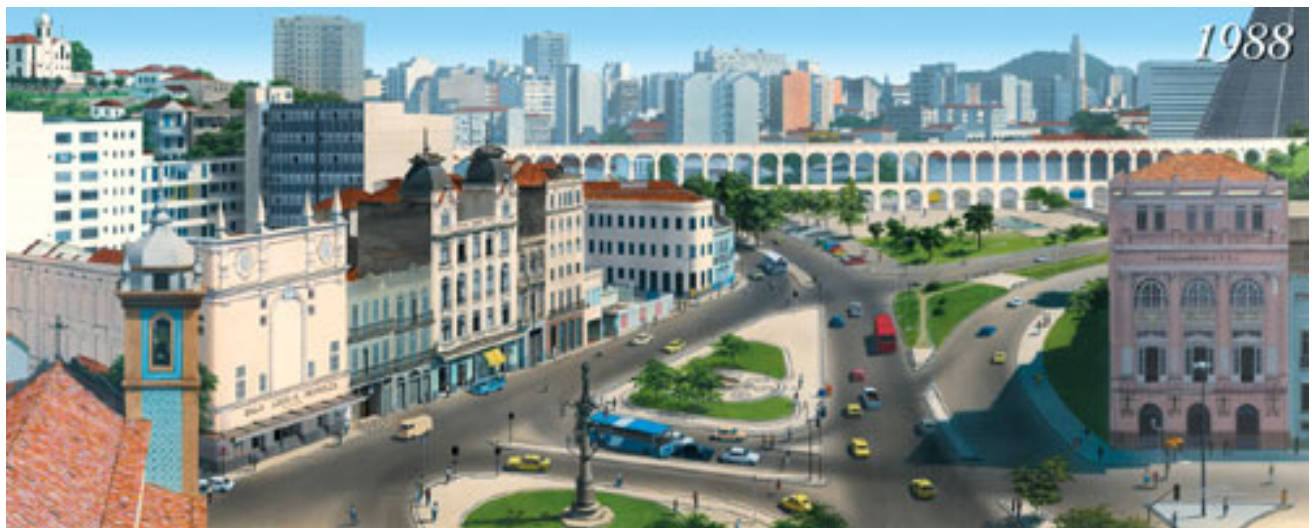

Figura 14

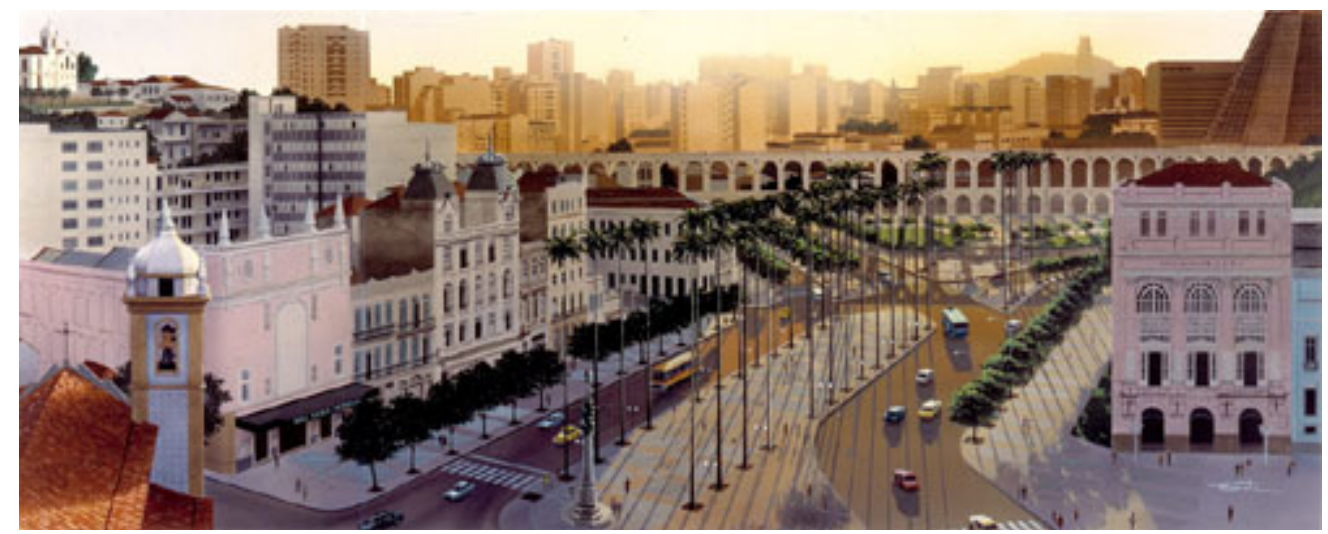

Figura 15 
A materialização da Lapa no espaço urbano é realizada pela permanência tanto da Igreja quanto dos Arcos. Pelos postais acima podemos perceber que o bairro passou por várias transformações, mas seus símbolos permanecem lá, até mesmo no último postal - uma projeção urbanística que não se concretizou - como para lembrar que a Lapa continua a existir. As transformações físicas pelas quais a Lapa passou, e que influenciaram decisivamente na sua ascensão e queda, não retirou e nem sequer modificou seus maiores símbolos. Eles continuam lá para lembrar-nos de que a Lapa de outrora vive sob os Arcos e ao redor da igreja. 


\title{
4. \\ Eis que ressurge das cinzas!
}

\author{
A Lapa \\ Está voltando a ser \\ A Lapa \\ A Lapa \\ Confirmando a tradição \\ A Lapa é o ponto maior do mapa \\ Do Distrito Federal \\ Salve a Lapa ${ }^{41}$
}

\begin{abstract}
(...) os Assírios chamam-na de fênix. Depois de ter vivido quinhentos anos, faz um ninho nos ramos de um carvalho ou no alto de uma palmeira. Nele ajunta cinamomo, nardo e mirra, e com estas essências constrói uma pira sobre a qual se coloca, $e$ morre, exalando o último suspiro entre os aromas. Do corpo da ave surge uma jovem fênix, destinada a viver tanto quanto a sua antecessora. $^{42}$
\end{abstract}

Assim aconteceu com a Lapa, morreu exalando seus últimos aromas. Mas após um grande período de hibernação, ressurge das cinzas, gloriosa, como uma fênix. Vestido rendado, sandália rasteira, flor no cabelo: é ela, pronta para a festa. De senhora cansada e decadente, rejuvenesce para cair no samba. É a nova Lapa!

De algumas décadas para cá, um grande esforço tem sido feito por parte da iniciativa privada e de ações governamentais para a recuperação e revitalização do espaço da Lapa. Tal revitalização é fortemente apoiada no imaginário que se construiu sobre o local nas décadas de 20 e 30, nas quais a Lapa consolida-se como berço da boemia intelectual carioca. Apoiadas nesse imaginário, várias intervenções tem sido realizadas. Busca-se restaurar essa imagem de paraíso perdido construído por meio dos discursos boêmios produzidos quando a Lapa já entrava em seu período de decadência.

Ao longo de três décadas $(50,60$ e 70$)$ a região recebeu inúmeras intervenções no seu espaço físico. A modificação do espaço, por meio de suas

\footnotetext{
${ }^{41}$ Samba de Herivelton Martins e Benedito Lacerda. In: LUSTOSA, 2001:88

${ }^{42}$ Descrição de Ovídio sobre a fênix. In: BULFINCH, Thomas. O livro de ouro da mitologia. Histórias de deuses e heróis. Trad. David Jardim. Rio de Janeiro: Ediouro, 2006.
} 
reformas modernizadoras, acompanhada pelo êxodo da boemia, por motivos já supracitados, convergiu para uma degradação do lugar.

No entanto, a partir 1970 é possível detectar o início do processo de inversão na lógica das intervenções para a área central liderada pelo poder público. Assiste-se, nesta década, a uma preocupação no desenvolvimento de políticas que aliassem o desenvolvimento urbano à preservação das antigas estruturas pré-existentes no espaço urbano.

Um conjunto de questões e eventos colaborou para o processo de inversão na lógica de intervenção do poder público na área central, dentre eles: o movimento de descentralização das políticas de preservação do patrimônio histórico que permitiu a emergência de políticas municipais de preservação; o movimento das comunidades cariocas atingidas pelos processos de renovação urbana, principalmente as mobilizações de associações de bairros, como o do Catumbi, e as mobilizações contra a demolição de importantes edifícios da área central. Esses movimentos foram acompanhados pela imprensa, que teve um importante papel na divulgação dos episódios de demolição ao expor os diferentes pontos de vista e pela circulação do debate acerca da preservação e conservação da memória construída da cidade do Rio de Janeiro. (MACEDO, 2004: 3)

Segundo Lima, toda manifestação que se origine de conceitos históricos, ambientais, paisagísticos, arquivísticos, etnográficos, podem contribuir para a consolidação da identidade de um grupo social. Desta forma, com a restauração e preservação de bens culturais de um determinado segmento da sociedade,

visa-se na realidade promover-lhe a identidade cultural, pois ao perder ou ver alteradas expressivas manifestações arquiteturais e paisagísticas, o indivíduo perde também os referenciais que permitem sua identificação com a cidade em que vive, em especial quando tecidos antigos são arrasados e novos objetos urbanos passam a compor a paisagem, com massivas alterações na escala do lugar. (LIMA, 2007:79).

A partir da década de 80, com o Projeto Corredor Cultural ${ }^{43}$, cuja concepção data de 1979, dá-se início a um processo de proteção paisagística e

43 LEI N. 506 DE 17 DE JANEIRO DE 1984 - Sancionada pelo então prefeito Marcelo Alencar. D.O. RIO. ANO X No 14 PARTE IV - RIO JANEIRO - QUINTA - FEIRA - 19 DE JANEIRO DE 1984. Disponível em:

http://www0.rio.rj.gov.br/patrimonio/pastas/legislacao/centro_lei506_84_corredor_cultural.pdf Acesso em: 20 de agosto de 2013. 
patrimonial do centro do Rio de Janeiro. Tal projeto trouxe uma completa remodelagem para o bairro, visto que "é o primeiro projeto de "preservação" da área central da cidade do Rio de Janeiro que abrange um conjunto de edifícios dos setores da Lapa, Cinelândia, Largo do São Francisco, Largo da Carioca, o Saara, Praça XV e imediações; e extrapola a pura e simples preservação de edifícios isolados." (IRIAS, 2007:21). As consequências desse projeto podem ser vistas até hoje.

O Projeto Corredor Cultural ainda que funcionasse como mais uma intervenção governamental no espaço físico da Lapa, diferentemente das outras modificações que contribuíram para a decadência do bairro, possibilitou uma restauração do espaço urbano, dando início ao processo de retomada cultural da Lapa.

De acordo com Brandão (2011), algumas ações particulares também contribuíram para mudanças nos usos e usuários da região da Lapa na década de 1980. Como por exemplo, a implantação do Circo Voador ${ }^{44}$ em outubro de 1982. Inclusive foi o grupo atuante no Circo Voador que impediu a demolição da Fundição Progresso ${ }^{45}$, em 1983. O prédio, que ia ser demolido, após a mobilização do grupo e sua articulação com o poder público, foi restaurado e transformado em centro cultural.

A Fundição Progresso, hoje, é um espaço cultural onde ocorrem shows, eventos, festas, exposições, cursos e oficinas ligados à arte. É uma das poucas edificações remanescentes no entorno dos Arcos, após remodelação de trecho do bairro na década de 1950 para abertura de uma grande avenida. O imóvel representa exemplo de arquitetura industrial da época no Rio de Janeiro. (BRANDÃO, 2011:9)

Um dos idealizadores do Circo Voador, Perfeito Fortuna, cedeu uma entrevista à revista Guia Cultual do Rio de Janeiro falando sobre a "posse" desse espaço tão importante para a revitalização da Lapa.

\footnotetext{
${ }^{44}$ O Circo Voador nasceu em janeiro de 1982, como um projeto de verão na praia do Arpoador. Três meses depois de instalado, o Circo foi despejado da praia. Uma rádio carioca formou uma parceria com o Circo Voador e em outubro de 1982 ele instalou-se na Lapa, com um projeto chamado Rock Voador. Além dos shows e festas, sua atividade principal, o Circo Voador tem algumas atividades sociais, como a Creche do Circo que a tende a 80 crianças em horário integral e que existe desde 1982.

${ }^{45} \mathrm{O}$ espaço ocupado era onde funcionava uma fundição de fogões e cofres. (www.fundicao.org) consulta em 10 de junho de 2013).
} 
Eu vim em 1982 para cá com o Circo Voador, que era uma coisa da zona sul feita por artistas da zona sul. Trinta e seis grupos, Asdrúbal Trouxe $o$ Trombone e vários de dança e de circo. Quando viemos para a Lapa, porque na época a prefeitura não nos deixou ficar na zona sul, nós achamos este lugar aqui, que era cheio de mendigos, um horror e muito escuro. Mas mesmo assim viemos para cá. Em frente tinha a Fundição Progresso que estavam derrubando. Na hora que nós sacamos esse terreno, começamos a negociar com o estado, mas o próprio estado mandou derrubar a Fundição para tudo fazer parte do terreno da Catedral como estacionamento. Nós não deixamos derrubarem a Fundição, ficamos um tempo na luta até que o Chagas Freitas (governador) sustou a demolição. A gente começou a montar o Circo em frente, como um acampamento de obra, produzindo coisa, inventando e esperando para entrar na Fundição e construir um centro cultural. ${ }^{46}$

Para Fortuna, o Circo Voador "estourou" porque sua arquitetura andaimes de obra, junto com arquibancada de madeira - favoreceu 0 aparecimento de uma arte mais contemporânea, mais urbana como o rock and roll. Nessa época, a Lapa passa atrair novamente o olhar dos cariocas.

No início dos anos de 90, a Lapa ainda estava pouco movimentada. No entanto já se fixava a ideia de um retorno a suas origens culturais. Com os Projetos Quadra da Cultura e Distrito Cultural da Lapa ${ }^{47}$, alguns sobrados de propriedade do estado, na Avenida Mem de Sá, foram cedidos para instituições artísticas intelectuais, possibilitando, juntamente com Fundição progresso e o Circo Voador, uma renovação cultural com eventos, festas e espetáculos.

O projeto Quadra da Cultura contribuiu muito para sinalizar a área como um local em vias de recuperação. Estabeleceu-se, então um circuito que incluía espetáculos, bailes e festas no Circo Voador, na Fundição Progresso, nas casas da Quadra da Cultura, e no Asa Branca. Posteriormente, surgiu, também, uma nova área de atividades boêmias composta pelos restaurantes e bares do trecho inicial da Rua Joaquim Silva, da Rua Visconde de Maranguape e do Largo da Lapa, que

\footnotetext{
${ }^{46}$ Revista Guia Cultural do Rio de Janeiro. Ano I - No 01 - Abril de 2004. Impresso. Entrevista Perfeito Fortuna.

${ }^{47}$ Diferentemente do Corredor Cultural que pertencia à municipalidade, esses projetos pertenciam ao Governo do Estado do Rio de Janeiro. O governo do Estado através da Secretaria de Cultura do Estado, impulsionava, por meio desses projetos, e participava mais efetivamente do processo de recuperação do espaço urbano da Lapa.
} 
passaram a ter atividades noturna com música ao vivo (MAGALHÃES, $2006)^{48}$

Irias (2007) cita três momentos cruciais para essa reestruturação do bairro da Lapa: o primeiro, relacionado à revitalização da Rua Joaquim Silva no retorno a vida boemia da Lapa após o seu período de decadência; o segundo, relacionado ao Projeto Pólo Novo Rio Antigo, responsável pela reestruturação da Rua do Lavradio e de seu conjunto arquitetônico, que se estruturou a partir da coalizão entre pequenos comerciantes e a prefeitura do Rio de Janeiro. E o terceiro, que compreende a chegada do capital imobiliário na Lapa, trazendo novos interesses políticos a renovação urbana.

A Rua Joaquim Silva e seu entorno mais próximo firmaram-se como um importante eixo dessa recuperação da Lapa.

\begin{abstract}
Na passagem da primeira para a segunda metade da década de 90, a Rua Joaquim Silva já havia se tornado referência para os muitos estilos diferenciados que transitavam no bairro. A promoção de eventos de música, de todos os estilos, desde o Jongo da Serrinha, passando pelo maracatu, forró, samba, salsa, funk e outros gêneros musicais, contribuíam para o sucesso deste eixo cultural em se tratando de ponto de encontro das mais variadas tribos urbanas. O público jovem foi atraído rapidamente para presenciar ali os diferentes eventos culturais que, rapidamente, emergiam. (IRIAS, 2007:26)
\end{abstract}

A presença de casarios, sobrados e a antiga rede de hotéis, ligados ao funcionamento da prostituição que existira no bairro, deram lugar a botequins que serviram como novos espaços de sociabilidade. Rapidamente, desenvolveram-se aglomerações de pessoas que se reuniam para vender produtos artesanais e se divertir. As novas atividades expandiram-se e passaram a ocupar também, além do trecho inicial da Rua Joaquim Silva, a Visconde de Manguarape e o Largo da Lapa. Nos últimos anos da década de 90, assim como se verificará a partir dos anos 2000 (até os dias atuais), as atividades culturais encontram trechos da ruas Mem de Sá, Riachuelo e Lavradio, esta última com grande importância do ponto vista arquitetônico.

\footnotetext{
${ }^{48}$ ALAN MAGALHÃES (Diretor Administrativo do SindMusi). Entrevista concedida dia 18 de outubro de 2006.15. In: REQUIÃO Luciana. O trabalho produtivo do músico nas casas de shows da Lapa:um estudo de caso. Revista Trabalho necessário. Issn:1808-799x. ano 7 - número 8- 2009.
} 
Iria (2007) atenta para o fato de que o surgimento do eixo de expansão da reforma urbana, delineado pela Rua Joaquim Silva e entorno próximo, caminhou muito mais no sentido de revigorar o comércio do bairro do que no sentido de fazer valer os interesses da população residente no bairro.

Lembremos também que o projeto do Corredor Cultural, criado em 1979, já vinha sendo implementado não só no bairro da Lapa, mas também em outros espaços da área central. Destacando-se desde os seus primórdios a questão da preservação do conjunto arquitetônico do centro histórico, este projeto foi se transformando rapidamente para atender os anseios dos diferentes interesses políticos presentes no território compreendido pelo projeto. As propostas de preservação do conjunto arquitetônico e os seus respectivos desdobramentos, passaram, outrora, despercebidas pela sociedade civil. Na verdade, serviram muito mais para minimizar problemas passados, a exemplo da destruição do conjunto arquitetônico, do que para delinear novos caminhos para a população do bairro, como o acesso a serviços e a democratização da vida cotidiana neste espaço. (IRIA, 2007:31)

Mas se por um lado este projeto original modificou-se com o tempo, aparecendo, portanto, as críticas e os problemas relacionados a sua concretização, como a reincidência da visão mais ligada ao urbanismo; por outro lado ele teve sua importância como marco inicial das diferentes ações pelas quais vem passando o território da Lapa. Este projeto pode ser identificado como marco inicial da retomada da Lapa. (IRIA, 2007).

Empresários, aproveitando o momento favorável de renascimento bairro boêmio, reuniram-se com comerciantes locais e com poder público para incrementar o comércio da região. Sendo assim, surgiu o Projeto Polo Novo Rio Antigo, pioneiro no que diz respeito ao aproveitamento e investimento no potencial econômico do bairro da Lapa.

Criado em 2005, o Polo Novo Rio Antigo logo se transformou num importante instrumento de revitalização do Centro Histórico da cidade do Rio de Janeiro, ao reunir empresários e profissionais das áreas de cultura, lazer, gastronomia, turismo, comércio e serviço em torno de uma única bandeira: fortalecer o associativismo e promover o desenvolvimento das regiões da Cinelândia, Lapa, Rua do Lavradio, Praça Tiradentes e Largo de São Francisco que viviam abaladas pelos sucessivos abandonos do poder público e evasão da iniciativa privada. ${ }^{49}$

Os idealizadores do projeto, pautado em três vetores de desenvolvimento: cultura, gastronomia e memória, definem-no como principal agente de mudança

\footnotetext{
${ }^{49}$ In: http://www.novorioantigo.com.br/quemsomos
} 
local, atuando sem cansar para aumentar a competitividade e produtividade das empresas com investimento na qualidade de produtos oferecidos e geração de externalidades positivas capazes de ampliar a atratividade local, tais como melhoria de infraestrutura, limpeza, segurança, diferenciação e promoção da região como destino compra e lazer.

Um dos eventos organizados pelo projeto é a Feira do Lavradio, organizada mensalmente na Rua do Lavradio. Esta rua é uma das mais importantes da história da cidade do Rio de Janeiro e da Lapa. Ela mantém a arquitetura dos casarões no lado direto praticamente intacto. Nesta rua, mesclamse quitandas, restaurantes, bares, brechós, antiquários, casas noturnas, moradias populares e casarões. Ela serve também como ponte entre a Lapa e Praça Tiradentes e facilita a proximidade com a Cinelândia, o Largo da Carioca, a Praça $\mathrm{XV}$, o Campo de Santana, dentre outras atrações igualmente importantes do Centro Histórico.
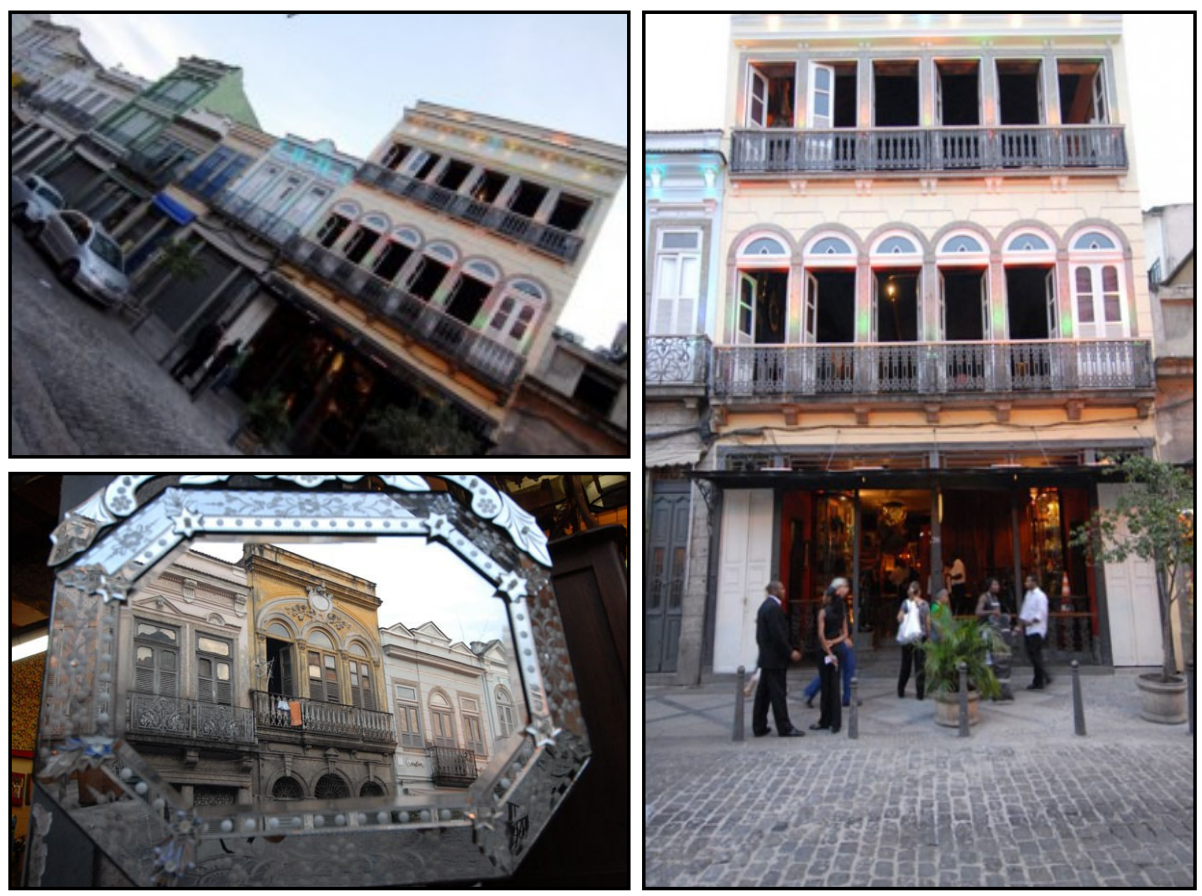

Figura 16 - Imagens da Rua do Lavradio - Disponíveis em: http://www.novorioantigo.com.br/galeria/memorias/rualavradio. Acesso em: $24 / 11 / 2013$

A Feira realizada na Rua do Lavradio (Figura 17) pode ser considerada como uma das principais protagonistas para o fenômeno de retomada e 
redescoberta do bairro da Lapa, tendo vista a sua contribuição cultural e econômica, visto que atrai um grande número de visitantes para o bairro.
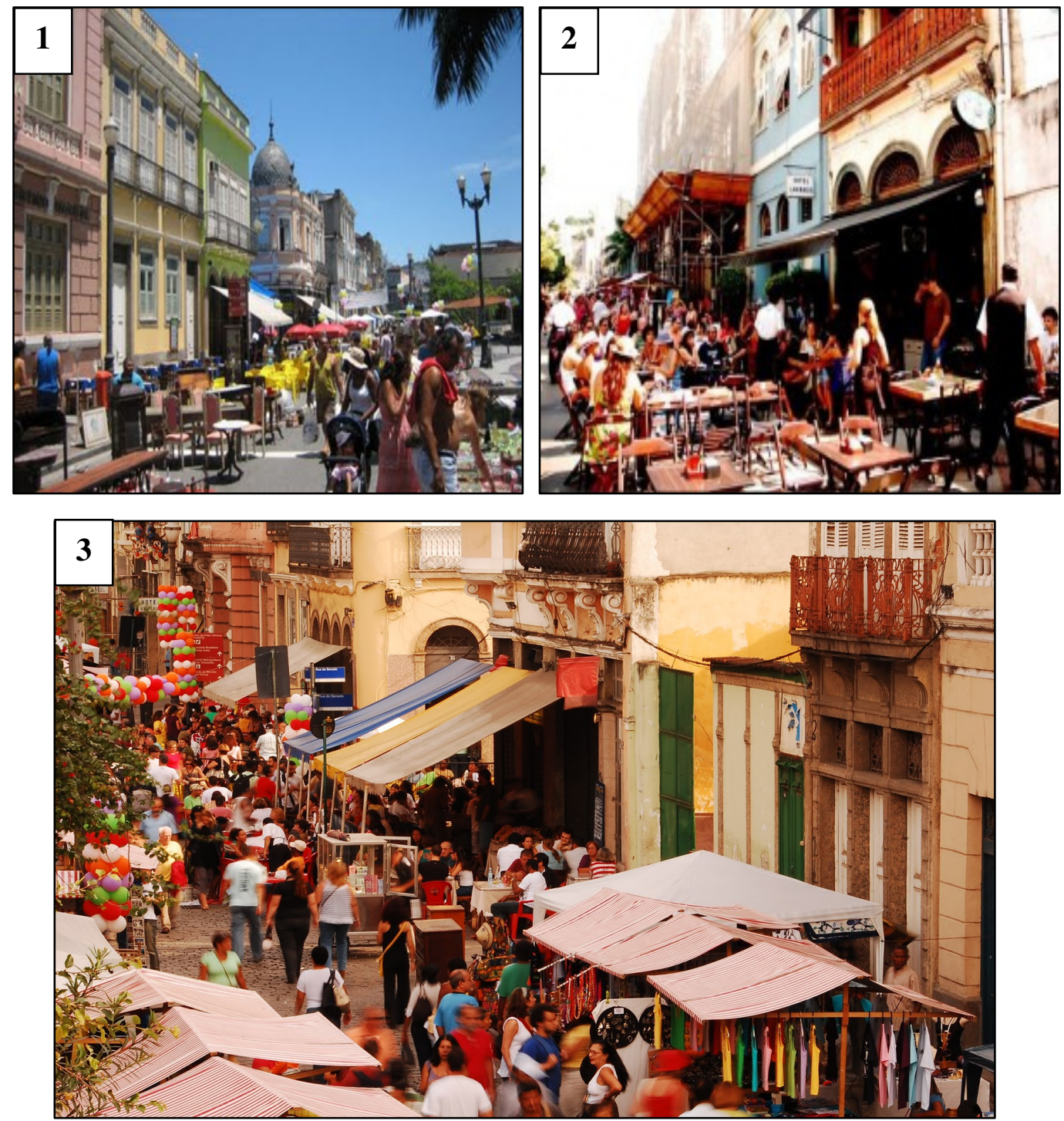

Figura 17 - Imagens da Feira do Lavradio - Disponíveis em -

1: http://neurasteniaeglamour.blogspot.com.br/2011/05/boa-do-findi-feira-do-lavradio.html

2: http://www.saladacorporativa.com.br/2011/08/feira-rio-antigo-rua-do-lavradio/

3 - http://www.riomaisbarato.com.br/events/feira-do-lavradio/

A Rua do Lavradio reveste-se de um clima diferente no primeiro sábado de cada mês. Antiquários, bares, expositores, restaurantes ao ar livre, muita gente em meio ao casario antigo e contornado por memórias de uma Lapa que está renascendo. Pelas fotos, podemos perceber a grande movimentação que a feira 
traz para o bairro. Como ela ocorre durante todo o dia, o visitante que fica até o fim da tarde já se encontra com a Lapa noturna.

Essa renovação cultural da Lapa somada às promessas de revitalização de toda a área central do Rio de Janeiro e às medidas incentivadoras, por parte do Governo, aos investimentos imobiliários têm contribuído para um incremento do setor imobiliário na região.

A Lapa torna-se, então, uma peça importante deste grande quebra-cabeça que vem sendo montado em todo território da área central, talvez por ser o primeiro bairro da área central a contemplar os dois principais objetivos almejados pelo Plano Estratégico da Cidade do Rio de Janeiro; a condição de ser uma referência histórico-cultural e a sua perfeita inserção no mercado de moradias destinado a classe média da cidade. (IRIA, 2007:51)

E como marco dessa renovação urbana, aparece o condomínio Cores da Lapa que já é considerado um símbolo de renovação do mercado imobiliário carioca ${ }^{50}$. O grande sucesso de vendas alcançado trouxe um incremento para o setor no centro da cidade.

O resultado surpreendente nas vendas do Cores da Lapa mudou a visão do mercado imobiliário carioca. Os próprios concorrentes reconhecem que, após a Lapa, a perspectiva de investimento foi multiplicada e os incorporadores passaram a olhar com atenção para todas as áreas da cidade. $^{51}$

A grande procura pelo empreendimento e o êxito das vendas, pode ser considerado um reflexo dessa tão proclamada revitalização do bairro. No entanto, não podemos olhar para esse fenômeno de maneira ingênua. Duarte (2009) sinaliza que ainda que o lançamento do condomínio tenha revigorado o mercado imobiliário no bairro, e no centro da cidade, a publicidade em torno desse lançamento tratava sempre de enfatizar que o condomínio seria dotado de todos os serviços necessários ao conforto e ao atendimento das necessidades da vida cotidiana dos futuros moradores que passariam, assim, a se sentir dentro de uma

\footnotetext{
${ }^{50}$ Com seis edifícios e um total de 688 apartamentos, o empreendimento - situado no antigo terreno da Cervejaria Antártica entre a rua do Riachuelo e a rua Mem de Sá (no bairro da Lapa) foi totalmente vendido em um curto espaço de tempo: entre o início da divulgação publicitária e o dia oficial marcado para o lançamento.

${ }^{51}$ ALVARENGA, Telma. A Lapa e outras surpresas Bairros esquecidos pela indústria da construção mostram seu valor no mercado. http://veja.abril.com.br/vejarj/290306/p_012.html
} 
cidadela autônoma com relação à vizinhança imediata ${ }^{52}$. Embora não claramente explicitado, era como se os empreendedores estivessem vendendo a possibilidade de morar na Lapa totalmente protegido da Lapa. "Ou seja, um gueto de classe média em meio à Lapa dos pobres”. (DUARTE, 2009:11). Essa postura de segregação é antiga e tem sido também utilizada nas atuais políticas públicas referentes ao bairro.

\section{1.}

\section{As atuais políticas públicas no bairro da Lapa}

A Lapa é o mais novo bairro do Rio. Conhecida como o berço da boemia carioca, era uma área que oficialmente pertencia ao centro do Rio e só veio tornarse bairro em 2012, quando prefeito Eduardo Paes sancionou a Lei $5.407^{53}$. A criação do bairro foi realizada por meio do desmembramento do território do Centro. A Lapa pertence a I Região Administrativa, tendo os seguintes limites (Figura 17):

\footnotetext{
${ }^{52}$ Entre os serviços da infra-estrutura condominial oferecidos constavam uma grande praça central em torno da qual se encontravam piscinas, quadra poliesportiva, sala de fitness, SPA, judô, balé, pista de boliche, salão de jogos, salão para festas, espaço gourmet, churrasqueira, cyber café, lavanderia, etc.

${ }^{53}$ LEI No 5.407, de 17 de maio de 2012. Cria o Bairro da Lapa, pela subdivisão do Bairro do Centro, área da AP 1, II Região Administrativa. Disponível em: http://mail.camara.rj.gov.br/APL/Legislativos/contlei.nsf/7cb7d306c2b748cb0325796000610ad8/e e3fcc69d06e73bd03257a02004f4969?OpenDocument. Acesso em:02/10/2013
} 


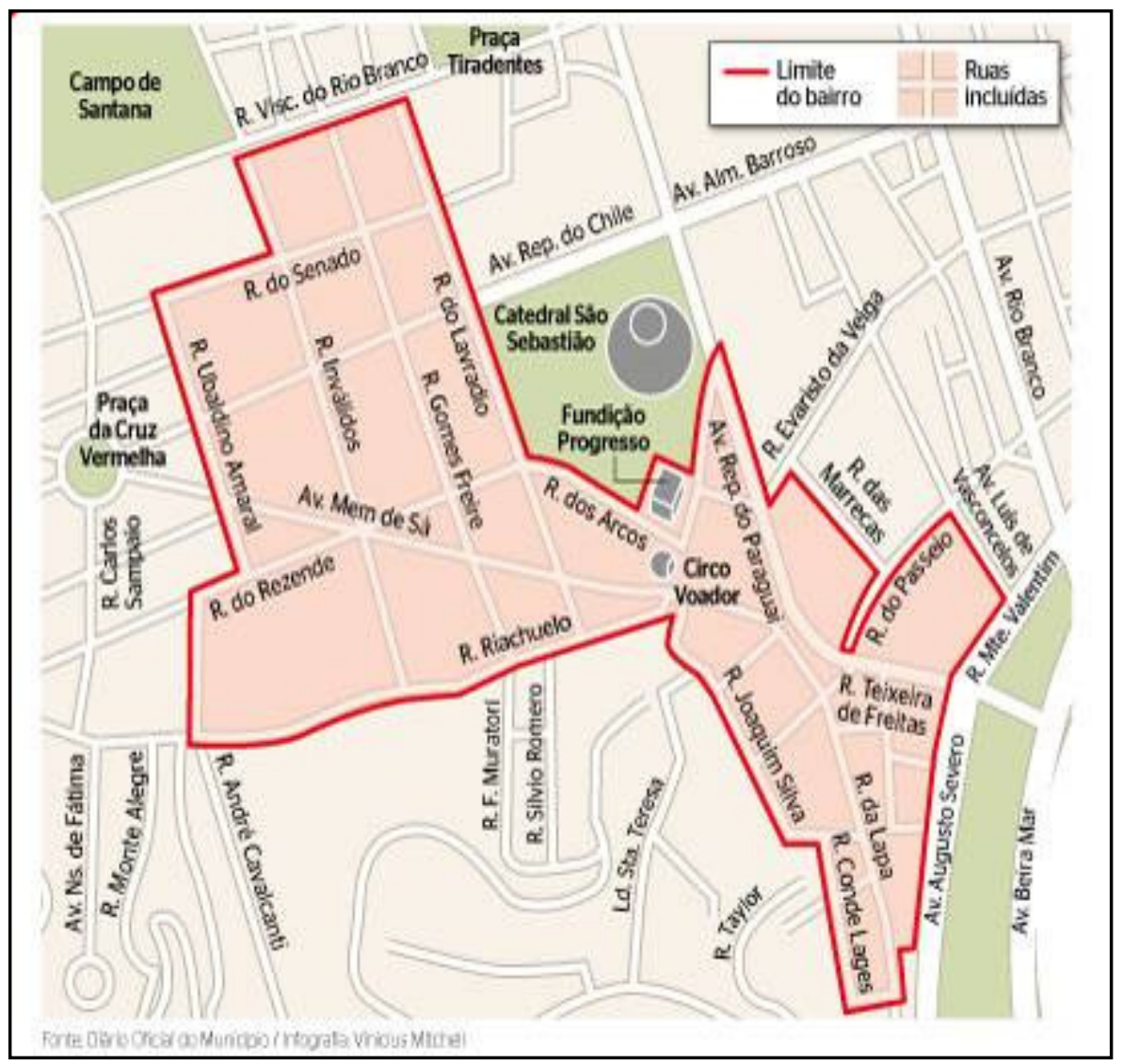

Figura 18 - Limites do novo bairro da Lapa. Disponível em: $<$ http://extra.globo.com/casa/transformacao-da-lapa-em-bairro-esperanca-de-maisinfraestrutura-para-moradores-5099558.html>. Acesso em 15/01/204

Para o prefeito Eduardo Paes a assinatura desse decreto é a legitimação de um lugar que faz parte da história da cidade. A Lapa, a partir de então, deixa de ser apenas conhecida como reduto boêmio para ser um bairro reconhecido geograficamente na cidade. ${ }^{54}$ Segundo o subprefeito do Centro, Luiz Claudio Vasques, em entrevista ao jornal Extra, ${ }^{55}$ a assinatura do decreto que transforma a Lapa em bairro é simbólica e vem demonstrar o quanto e como a prefeitura tem se importado com a região, não só como polo boêmio, mas, principalmente, por sua relevância cultural. Os moradores acreditam que com a transformação da região

\footnotetext{
${ }^{54}$ ENTREVISTA COM PREFEITO EDUARDO PAES PARA A REVISTA "LAPA LEGAL RIO”. Qui, 05 de Julho de 2012 12:31 I Disponível em: http://www.dmptrio.org.br/index.php?option=com_content\&view=article\&id=987:entrevista-comprefeito-eduardo-paes-para-a-revista-lapa-legal-rio. Acesso em 12/11/2013.
}

\footnotetext{
${ }^{55}$ Disponível em: http://extra.globo.com/casa/transformacao-da-lapa-em-bairro-esperanca-de-maisinfraestrutura-para-moradores-5099558.html\#ixzz2vZK2rx9W - acesso em 27/09/2013
} 
em bairro, os frutos para o local tendem a ser positivos, visto que novos investimentos em infraestrutura, segurança e coleta de lixo serão realizados. Esse decreto também foi visto com bons olhos pelo mercado imobiliário e pelos comerciantes do bairro, uma vez com a melhoria da infraestrutura, a Lapa se consolidará como um mercado em ascensão.

Tal preocupação, por parte do governo, em criar na Lapa um ambiente favorável ao consumo, tem reverberado nas ações públicas que tem sido tomada nos últimos anos. Se no início da recuperação do território da Lapa os projetos idealizados se referiam apenas à recuperação física dos casarios, como visto acima, nesta etapa os projetos destinam-se também a valorização da riquezas culturais do bairro, além de garantir segurança e bem-estar ao moradores e visitantes do bairro. As intervenções no (re)ordenamento urbano incluem drenagem, pavimentação, limpeza urbana, acessibilidade, iluminação, segurança, dentre outras. Dois projetos têm sido norteadores dessa recente "preocupação governamental" com o bairro: o Lapa Legal e o Lapa Presente. objetiva:

O projeto Lapa Legal foi lançado em 2009 pela prefeitura do Rio e

valorizar a 'vocação multicultural' da Lapa e suas riquezas artística, arquitetônica e histórica, com o aproveitamento do potencial cultural e turístico dessa área, a regularização urbana da Lapa e de seu entorno, a preservação do patrimônio arquitetônico do Rio Antigo e o incentivo à captação de recursos e investimentos privados para a geração de empregos na região, resultando no desenvolvimento de atividades culturais, turísticas e econômicas da Lapa. (BRANDÃO, 2011:13)

E, segundo o prefeito Eduardo Paes, "é o primeiro conjunto de regras de civilidade para que a Lapa possa ter sua característica boêmia, de lugar do samba e da música em geral, sem que isso signifique uma bagunça completa." ${ }^{56}$ Estas ações interventivas na Lapa, ainda que incompletas, sublinha Vilas Boas (2012:12), "limpam" e organizam os movimentos que já ocorriam no bairro, ao mesmo tempo em que favorece o desenvolvimento do comércio e das casas noturnas na região. Através do mapa a seguir (Figura 19), pode-se perceber a enorme quantidade de áreas de lazer e comércio no bairro.

\footnotetext{
${ }^{56}$ http://noticiasrio.rio.rj.gov.br/index.cfm?sqncl_publicacao=18913 - acesso em 24/11/2013
} 


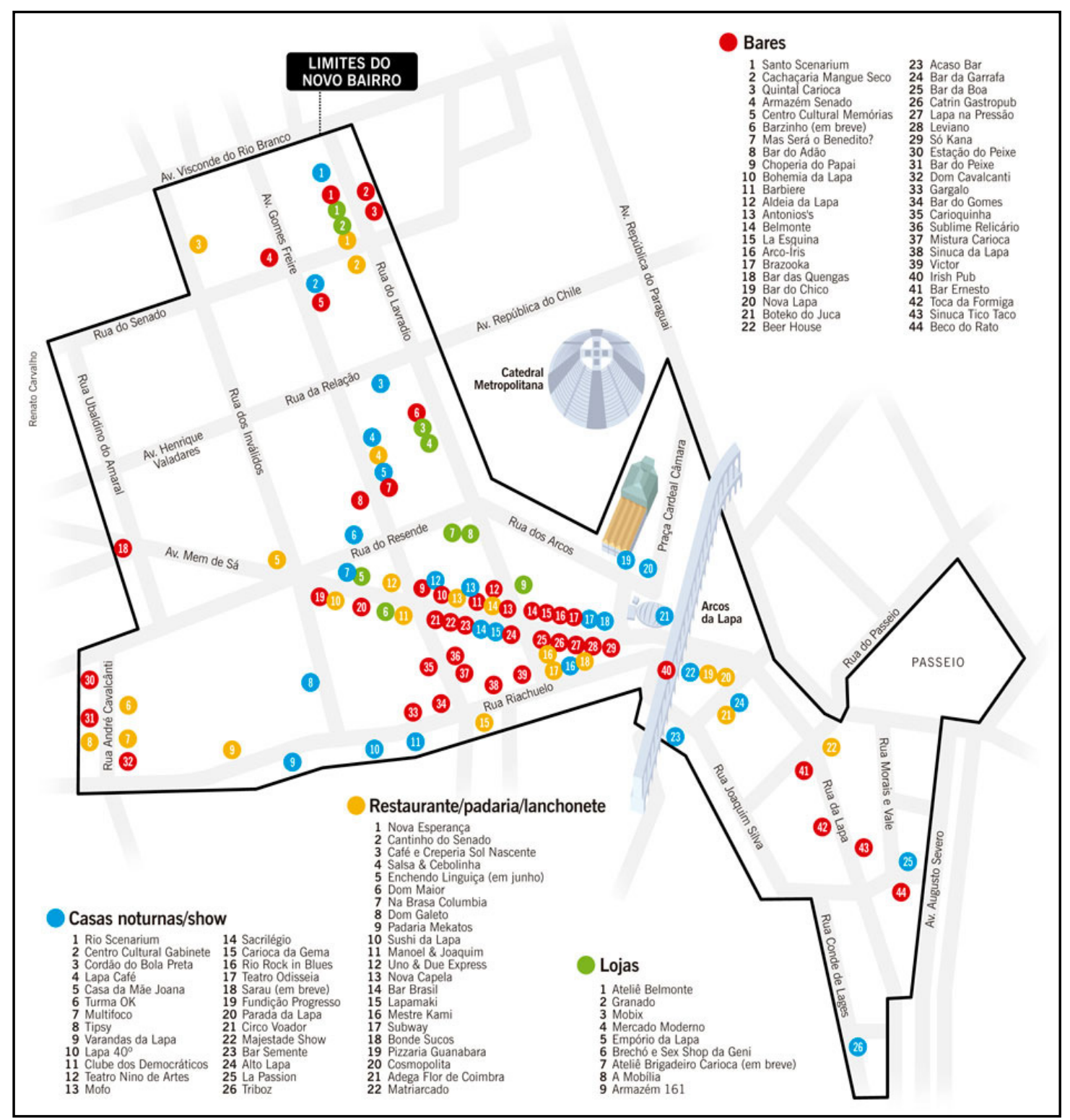

Figura 19 - Mapa dos novos limites da Lapa e as opções de consumo, cultura e lazer que o bairro oferece. Disponível em: http://oglobo.globo.com/infograficos/mapa-boemia-lapa/. Acesso em $12 / 11 / 2013$. 
O mapa publicado pelo Jornal o Globo, com o título: Um roteiro com 101 motivos para ir à região, mostra esse crescimento comercial no bairro. $\mathrm{O}$ incremento das atividades econômicas, tanto durante o dia quanto a noite, é possibilitado em parte pelas novas políticas de segurança voltadas para a Lapa. Para que as atividades sejam atrativas a um público cada vez maior, o Governo tem investido em ações que visam à segurança do espaço público. O mais recente projeto lançado pelo Prefeito Eduardo Paes é o Lapa Presente.

O Lapa Presente, realizado em parceria entre Secretaria Estadual de Governo do Rio de Janeiro (SEGOV) e a Prefeitura do Rio, foi criado devido ao aumento da criminalidade na Lapa. Com a pressão de moradores e comerciantes, o Governo do Estado decidiu criar um programa de patrulhamento permanente no bairro. De acordo com o secretário de Governo Wilson Carlos, "a operação tem por objetivo garantir o direito de ir e vir dos moradores e frequentadores do Distrito Rio Antigo, que envolve Lapa e adjacências." O projeto, que tem à frente o major da Polícia Militar Rodrigo Cereser, entrou em vigor no dia $1^{\circ}$ de Janeiro de 2014. A área de atuação do projeto pode ser vista a seguir (Figura 20):

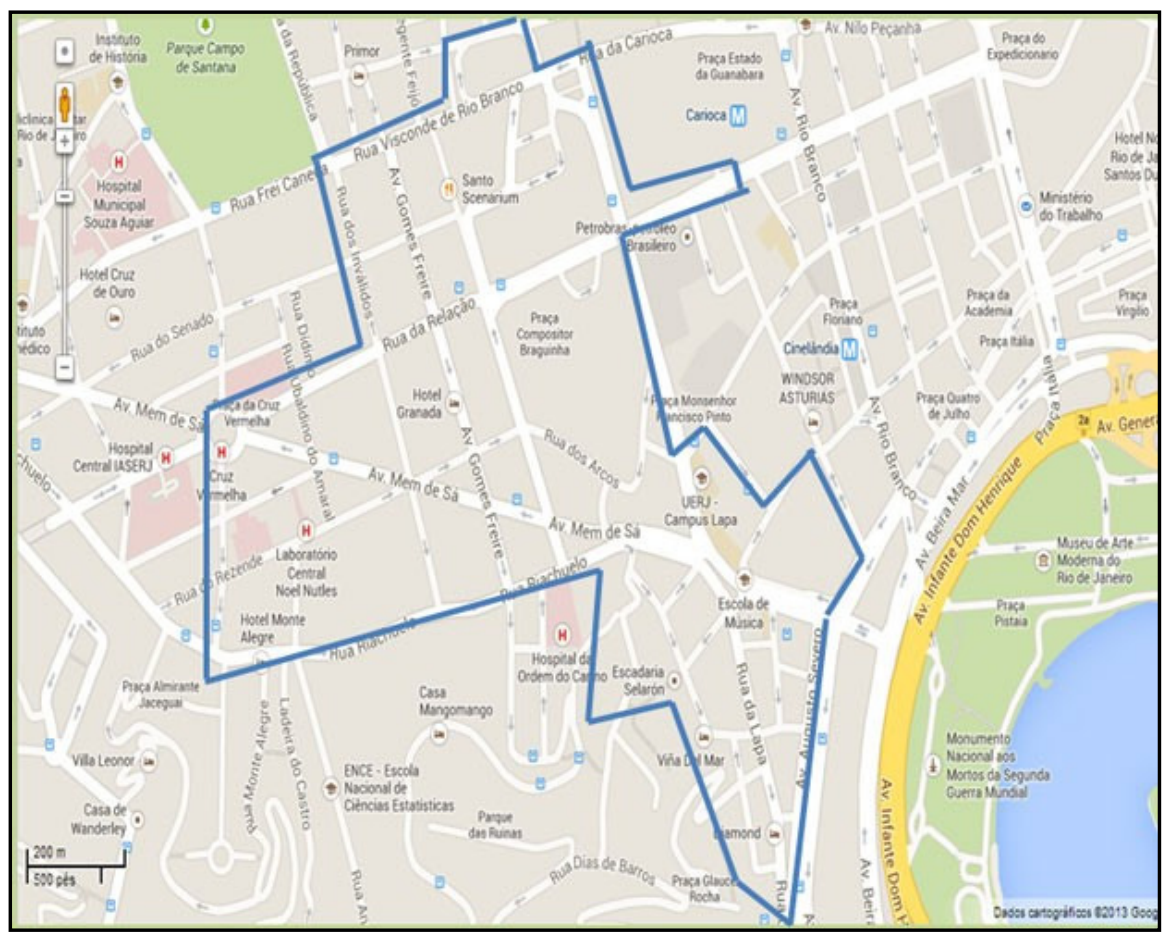

Figura 20 - Área de atuação da operação Lapa Presente. Mapa apresentado pela SEGOV (Foto: Secretaria de Estado de Governo do RJ). Disponível em: http://www.cbnfoz.com.br/editorial/brasil/rio-de-janeiro/17122013-62599empresarios-e-moradores-da-lapa-rio-discutem-seguranca-do-bairro. Acesso em: $14 / 02 / 2014$ 
Melhorias na iluminação pública, instalação de câmeras para monitoramento, poda de árvores, e ações de acolhimento e encaminhamento de moradores de rua estão entre as ações propostas pelo projeto, que conta também com uma unidade móvel da Secretaria de Assistência Social para atendimento de menores de rua usuários de drogas.

Em um mês de atuação, os agentes prenderam 25 foragidos da Justiça. Outras 460 pessoas foram detidas por porte de drogas, armas, roubo, furto e outros delitos. A ação, que acontece diariamente entre 21h e 5h30, também acolheu mais de mil moradores de rua. ${ }^{57}$

Os projetos acima citados almejam uma revitalização do espaço físico da Lapa e buscam por meio da reurbanização retomar a cultura boemia que se ausentou do bairro. É claro que essa retomada atende a interesses mercadológicos, no entanto, por meio dela, é possível vislumbrar novamente a boemia retornando ao bairro. Ela renasce (ou, na verdade, nasce?) envolta pela música.

\section{2. \\ A música e a renovação cultural da Lapa}

Em sintonia com Brandão (2011), podemos afirmar que a valorização cultural da Lapa ocorre duas maneiras: a partir de estratégias de apropriação deste espaço material; e por meio de investimentos culturais no centro antigo da cidade, que é dotado de elevado valor simbólico. O processo de revitalização da Lapa relaciona intervenções urbanas à preservação do patrimônio cultural e o estabelecimento de circuitos de lazer e entretenimento. (Os atuais circuitos de lazer de entretenimento no bairro podem ser conferidos no Anexo I e no mapa da Figura 18).

A presença do Circo Voador e apropriação da Fundição Progresso, como vistos anteriormente, contribuíram para o reacendimento da Lapa noturna. Mas foi no fim da década de 1990 que a "refuncionalização do casario antigo da Lapa para abrigar rodas de samba ganhou destaque, expandindo o movimento de valorização do samba como patrimônio imaterial da cultura nacional." (OLIVEIRA E

\footnotetext{
57 http://g1.globo.com/rio-de-janeiro/noticia/2014/02/lapa-presente-prende-25-foragidos-e-detem460-pessoas-em-1-mes-no-rio.html
} 
SANTOS, 2010:4). Lefê de Almeida foi um dos pioneiros e responsáveis pela revitalização do bairro da Lapa na década de 1990, e em entrevista a Herschmann (2007:33) conta o que o motivou a investir no bairro:

\begin{abstract}
A Lapa estava toda lá. Prontinha, mas ninguém aproveitava: Os Arcos, os casarios, os antiquários, etc. (...) Sempre freqüentei a Lapa desde 1975. De tanto freqüentá-la resolvi fundar e organizar a produção musical nos Arcos da Velha. Na verdade, revitalizar a Lapa sempre foi um sonho meu (...) Eu convivi com Mário Lago, inclusive ele foi meu parceiro de samba, de copo, de mesa e de botequim... Foi com ele que aprendi a amar a Lapa. (...) Nos anos 1990 chamei meu sobrinho , o Tiago Alvim (atualmente dono do Carioca da Gema) para trabalhar comigo nos Arcos da Velha. (...) A Lapa estava lá com tudo, mas só começou a revitalizar com a música, mais especificamente o choro e o samba. (...) A Lapa é importantíssima cultural e economicamente para o Rio.
\end{abstract}

Micael Herschmann, em Lapa, Cidade da Música (2007), destaca esse renascimento cultural da Lapa devido ao crescimento e a visibilidade cada vez maior de uma nova geração de músicos de "samba-choro de raiz" que vêm atuando num grande circuito cultural e atraindo para o bairro um número cada vez maior de pessoas interessadas nesse resgate da "tradição" do bairro. Esses novos boêmios, atraídos pela cultura da Lapa, "se configuram enquanto um público fragmentado, de classe média, com alto nível de escolarização e de informação, pois utiliza internet, rádios e jornais.". 58 . A boemia da Lapa é formada pelos jovens produtores de cultura, os músicos, e pelos jovens consumidores da cultura.

Os frequentadores da Lapa são compostos por aproximadamente $25 \%$ dos de turistas, o que demonstra a importância que a região vem alcançando na imagem da cidade, já o restante é composto por frequentadores assíduos, em sua maioria, jovens. O público que convive no circuito cultural da Lapa é de certa forma um pouco mais elitizado. (HERSMANN, 2007)

As pessoas que vão ali - até pelo menos 2006 - são na sua maioria jovens de faixa etária entre 18 e 34 anos (apesar de $25 \%$ ter entre 35 e 60 anos), não são casadas, pertencem às classes $\mathrm{A}$ e $\mathrm{B}$ e gastam em média 33 reais por programas; têm alta escolaridade (possuem ensino médio e superior),

58 Data-UFF, 2004 - In. HERSCHMANN, Micael. Lapa, Cidade da Música: desafios e perspectivas para o crescimento do Rio de Janeiro e da indústria da música independente nacional - Rio de Janeiro: Mauad X, 2007. 
e são muito bem informadas (lêem jornais e acessam a internet), declaram-se compradores regulares de $\mathrm{CD}$ e, na sua maioria, moram na Zona Sul e, de modo geral, nos bairros ricos do Rio. (Data- UFF, 2004. Apud: HERSCHMANN, 2007)

Um fato muito importante para o aparecimento dos jovens na Lapa é o fato de o bairro oferecer muitas opções de lazer. De acordo com Fróes, em entrevista a Herschmann, (2007), o frequentador da Lapa, em sua maioria, busca por opções de lazer que ofereçam experiências que os remetam à essência da identidade brasileira.

Hoje a Lapa, juntamente como com o centro do Rio Antigo, ressalta Herschmann (2007), é considerada pela maioria dos cariocas a verdadeira cidade da música ${ }^{59}$, constituindo-se como referência local, nacional e até internacional. A procura pela Lapa enquanto de espaço de cultura genuinamente nacional faz parte de um pensamento pós-moderno que busca renovar um compromisso identitário com a cultura local.

A dita pós-modernidade traz um aspecto muito importante no que diz respeito à questão das identidades. A noção do tempo e do espaço e a construção e percepção de etnia, raça e nacionalidade, que, "no passado, nos tinham fornecido sólidas localizações como indivíduos sociais", estão se modificando (HALL, 2006:9). A identidade nacional; "comunidade imaginada" (ANDERSON apud HALL, 2006:51) que continha tradições, referências espaço-temporais, normas, mitos e percepções acerca do povo (HALL, 2006); está se fragmentando.

Após as várias transformações pelas quais a identidade cultural passou, o homem, neste início de século, busca uma forma de identificar-se na sociedade em que vive. $\mathrm{Na}$ atual crise de identidade do homem pós-moderno, o grande dilema da sociedade é até onde a sua cultura está sendo engolida pelas identidades heterogêneas oferecidas pela indústria cultural.

O sujeito pós-moderno, conceptualizado não tem uma identidade fixa, essencial ou permanente. A identidade torna-se uma "celebração móvel": formada e transformada continuamente em relação às formas pelas quais somos representados ou interpelados nos sistemas culturais que nos rodeiam. (HALL, 2006:13)

\footnotetext{
${ }^{59} \mathrm{Na}$ Lapa tem sido chamada de a verdadeira cidade da música por ser a região onde mais se respira música no Rio - tem se verificado um grande crescimento das casas noturnas, na consolidação de um circuito cultural de samba e de choro - em contraponto à cidade da música projetada na Barra da Tijuca e dedicada à música clássica. (HERSCHMANN, 2007)
} 
Essa identidade cambiante do sujeito pós-moderno, essa celebração móvel, como afirma Hall (2006), em contínua relação com os sistemas culturais que rodeiam o indivíduo, tem entrado em colapso, visto que a mudança estrutural que tem acompanhado as sociedades modernas no final do século $\mathrm{XX}$ "fragmentando as paisagens culturais de classe, gênero, sexualidade, etnia, raça e nacionalidade, que, no passado, nos tinham fornecido sólidas localizações como indivíduos sociais" (HALL, 2006: 9) - têm abalado a ideia de integrados que os indivíduos construíam de si.

Esta perda de um "sentido de si" estável é chamada, algumas vezes, de deslocamento ou descentração do sujeito. Esse duplo deslocamento descentração dos indivíduos tanto de seu lugar no mundo social e cultural quanto de si mesmos - constitui uma "crise de identidade" para o indivíduo. (HALL, 2006: 9)

A crise experimentada pelo homem pós-moderno advém do fato de ele encontrar-se em uma sociedade que a todo o momento dissolve suas referências sociais e culturais, inserindo-o em um processo fragmentário. Nessa nova sociedade o sujeito é transformado em um híbrido cultural, sendo obrigando a assumir várias identidades, dentro de um ambiente que é totalmente provisório e variável, estando sujeito a formações e transformações contínuas em relação às formas em que os sistemas culturais o condicionam.

Esta realidade, em contrapartida, vem a ser extremamente profícua ao resgate e a valorização da cultura local, uma vez que ao conquistar e se inserir em novas culturas, o indivíduo, em um mecanismo de defesa da identidade, tende a querer resgatar a sua. $\mathrm{Na}$ pós-modernidade as identidades locais estão experimentando um sentimento de revalorização, Stuart Hall observa que "as identidades locais, regionais e comunitárias têm se tornados mais importantes." (HALL, 2006: 73)

A valorização das identidades e da cultura local é um vetor importante para o renascimento cultural da Lapa, pois agrega valor ao conjunto de atividades culturais que têm ocorrido no bairro nos últimos anos. Vejamos o que diz Ângela Leal e Plínio Fróes, em entrevista a Herschmann (2007:27) sobre o sucesso alcançado na Lapa nos últimos anos: 
$\mathrm{Na}$ verdade, acho que o grande sucesso alcançado pela Lapa deve muito à questão da identidade. Não é simples modismo. Tudo se produziu de maneira muito espontânea (...) Veja o choro, por exemplo. O choro é um clássico brasileiro. Você pega Pixinguinha: é um clássico. E isso estava jogado fora, tinha saído de moda. A moda é o que as gravadoras ditam e dizem que dará certo. Dá certo porque se massifica muito, mas tem o "pessoal cabeça", que está à procura de sua identidade, que procura a "cultura verdadeira" do seu país (...) e que necessita dela para promover sua auto-estima. Esse público vai encontrar isso hoje na Lapa e arredores. (Angela Leal - Liderança da Associação de Comerciantes do Centro do Rio Antigo (ACCRA), atriz e proprietária do Teatro Rival.)

A gente verificou numa pesquisa que é isso que o nosso público quer: cultura nacional, ou seja samba e choro. (...) O brasileiro tem se voltado para suas raízes, voltou-se para sua música. A maioria das pessoas se voltou para sua identidade, passando a freqüentar a Lapa. (Plínio Froes Liderança da ACCRA e proprietário das casas de espetáculo RioScenarium e Mangue Seco.)

Nos discursos produzidos acima, atenta-se para a valorização da sociabilidade através do consumo da cultura local e no reforço das noções de identidade e memória brasileiras. O consumo coletivo de choro e samba "oferece possibilidade de vínculos mais estáveis com o outro e com uma determinada percepção de grupo e comunidade nacional” ARAÚJO (2013:12). Angela e Plinio reforçam que os gêneros musicais supracitados agregam valores, símbolos e tradições. De acordo com Trotta (2006), os consumidores de música, na virada do milênio, ansiosos em reatar seus vínculos identitários realizam uma ligação entre presente e passado, buscando resgatar uma "tradição" perdida.

a tradição do samba (e em outros gêneros) se manifesta através da reverência a obras e compositores do passado, que se tornam representantes de um imaginário cujo eixo de valoração é a noção de continuidade, de permanência. Assim, um sambista adquire maior valor à medida que se demonstra mais próximo afetiva e esteticamente de símbolos desta tradição. (TROTTA, 2007:5)

Algumas figuras ligadas a música, e que buscam resgatar essa tradição, são apontadas como responsáveis pela renovação cultural do Bairro da Lapa, dentre elas a cantora Teresa Cristina, juntamente com o Grupo semente, e atualmente o Grupo Casuarina.

Teresa Cristina começou a cantar no Bar Semente, na Lapa, em 1998. A banda que acompanhava a cantora adotou o nome do bar em que cantavam na 
noite carioca. O grupo teve grande repercussão na Lapa e passou a apresentar-se também em outras casas noturnas do bairro, como o Carioca da Gema e o Centro Cultural. Segundo Herschmann (2007) a cantora Teresa Cristina, ao lado do Grupo Semente, é considerada por muito especialistas como um grande talento da nova geração que se dedica ao samba e se confunde com o recente renascimento da Lapa, tornando-se símbolo da recuperação do bairro.

\begin{abstract}
“a partir do minúsculo bar Semente e do samba que esses protagonistas lá faziam, a vida noturna do bairro passou por uma grande intensificação com a abertura de outros espaços destinados à música brasileira e, principalmente, o samba" (TROTTA, 2006:228)
\end{abstract}

Considerado pioneiro da nova geração de sambistas cariocas, o grupo Semente alcançou sucesso através de sua proposta voltada para o resgate de repertórios clássicos do samba, com o resgate das obras de Candeia e Paulinho da Viola.

Já o grupo Casuarina surgiu em 2001, durante um sarau em um curso de extensão da Universidade Federal do Estado do Rio de Janeiro. O Casuarina é composto por jovens residentes da Zona Sul carioca. Eles passaram a frequentar a Lapa juntos, inicialmente como espectadores e posteriormente como músicos, experimentando e consolidando a efervescência do bairro até então protagonizada por outros artistas, como o Grupo Semente, citado anteriormente.

Em 2005, ao lado dos conjuntos Galocantô, Anjos da Lua e Batuque na Cozinha, o Casuarina apresentou o projeto Samba em 4 tempos na Fundição Progresso (consagrada casa de show da Lapa), resgatando o repertório clássico do gênero e tocando algumas canções próprias. $\mathrm{O}$ primeiro álbum do grupo, intitulado Casuarina e lançado em 2005 pela gravadora Biscoito Fino, apostou no resgate de clássicos como Pranto de poeta (Nelson Cavaquinho e Guilherme de Brito), Laranja madura (Ataulfo Alves e Mário Lago) e Já Fui Uma Brasa (Adoniran Barbosa). $\mathrm{O}$ show de lançamento do álbum aconteceu no mesmo ano no Teatro Rival BR, no Rio de Janeiro, com a participação dos integrantes do Grupo Semente Pedro Miranda e Teresa Cristina, que participaram das faixas 400 anos de favela (Zé Kéti) e Suingue de Campo Grande (Novos Baianos), respectivamente. (ARAÚJO, 2012:13)

Pode-se perceber, pela citação acima, que a trajetória desses novos sambistas que ancoram na Lapa é semelhante: eles buscam recuperar o universo tradicional do samba. 
Assim como o samba, há muito o choro faz parte da cena musical da Lapa. Em meados da década de 90, houve uma grande proliferação de espaços com rodas de choro que tinham como público: profissionais liberais, músicos, jornalistas, escritores e estudantes. $\mathrm{O}$ circuito do samba-choro refletiu significativamente na reformulação dos espaços da região. (GOÉS, 2007). Para Herschmann (2007:45) é possível afirmar que associação entre esse dois gêneros musicais, no circuito cultural da Lapa, tende a fortalecer representação que sugiram uma "qualidade superior" da música tocada naquela região, uma vez que por oscilar entre o erudito e o popular, o choro parece afastar qualquer possibilidade de ver o samba tocado na Lapa pela ótica do popularesco. "Se o choro se converteu em uma "garantia de qualidade" para o samba, o samba, por sua vez, emprestou um pouco de sua popularidade e espaço de mercado ao choro."

O atual resgate do samba no Rio de Janeiro, seu consumo primordialmente coletivo é uma das possíveis formas encontradas pela juventude para consolidar um pertencimento, para reaver sua memória coletiva e construir outros laços sociais. Interessante pensar nesse resgate da tradição do samba na Lapa. As representações veiculadas sobre o bairro, baseadas no imaginário construído sobre o bairro como local de boemia e como espaço de música nacional e de "raiz", são um tanto quanto controversas.

As representações veiculadas da Lapa fazem referência a uma tradição da região como local de reunião da boemia e como espaço da música nacional e de "raiz". No entanto, as narrativas (citadas no capítulo anterior), que buscaram eternizar esse mito da Lapa boêmia, desmentem essa construção atual do imaginário do bairro como tradicionalmente sambista, ou como espaço de qualquer tipo de música nacional. Como Rangel descreve a seguir:

Mas, se New Orleans e a Lapa em muitos pontos se encontravam, uma grande deficiência marcava o bairro carioca - a sua música não era em absoluto a nossa música popular. Se, na cidade dos Estados Unidos encontrávamos um Jelly-Roll Morton, aqui não víamos o José Barbosa da Silva, o fabuloso Sinhô, perdido nas gafieiras do Catete, pianista do Flor de Abacate, seu supremo título. Também Pixinguinha, o Bexiguinha e não o "menino bom", como querem alguns estudiosos da língua africana que não existe, ficava no seu Inferno de Dante, vestido de diabo, lá para os lados da Praça Tiradentes. Não se misturavam com os tocadores de valsas vienenses, não davam confiança às mazurcas que o velho João Mangabeira soprava no seu desconjuntado clarinete. (...) Visitavam a Lapa, sim, de vez em quando, para "matar o tempo", comer siri e beber a 
melhor cerveja do Rio. (...) raras eram as aparições de um Donga, de um Chico Alves ou de um "Caninha", ${ }^{60}$

Lúcio Rangel ${ }^{61}$ escreve sobre este aspecto nada nacionalista da Lapa, no que dizia respeito à música e fala da ausência dos sambistas no bairro. Os sambistas frequentavam o bairro da Lapa mais para encontros sociais do que para compor. Era mais fácil encontrar sambista na Praça Onze, no Mangue e no Estácio do que na Lapa. "Os maiorais preferiam a Praça Onze, lembrando os velhos tempos da Tia Ciata; outros ficavam em seus subúrbios ou bairros distantes." O bairro do Estácio era ponto de reunião e o Mangue atraía por "seus cafés fartamente iluminados, sempre com choro de flauta, violão e cavaquinho (...) por lá a festa era fácil e mais barata."

A Lapa era sim um bairro musical, no entanto, "as polacas que aqui logo se transformavam em francesas, impunham o seu gosto nas pensões de mulheres e as cançonetas de Chevalier, substituíam o produto nacional." ${ }^{62} \mathrm{Na}$ Lapa não se ouvia e nem se criava samba. Só quando entrou em decadência, o bairro provocou meia-dúzia de sambas, "músicas que não nasceram lá, que usaram o tema apenas como motivo, sem maior ligação com a realidade." 63 . Por exemplo, “A Lapa”, composta por Herivelto Martins e Benedito Lacerda, em 1949, e interpretada por Francisco Alves, que conquistou os foliões no carnaval de 1950, quando composta já havia virado recordação, não era mais a Lapa dos grandes dias. E a presença de Noel Rosa, no bairro, com sua "Dama do Cabaré”, é tratada por Lúcio Rangel e Luís Martins, em Noturno da Lapa, mais como símbolo do que como realidade histórica, eles afirmam nunca terem visto o sambista na Lapa.

Quanto à música, ao que parece a Lapa não foi exatamente o que os sambistas cantam, há mais samba na Lapa que hoje renasce do que na Lapa do passado. O samba ao tomar o bairro como motivo, construiu um imaginário da Lapa associada a esse gênero musical. Apoiados nesse imaginário popular,

\footnotetext{
${ }^{60}$ RANGEL, Lúcio. A Lapa e a música popular. In: DAMATA, Gasparino. Antologia da Lapa. $3^{\text {a }}$ edição. Rio de Janeiro: Desiderata, 2007. p.81

${ }^{61} \mathrm{Ibid}$

${ }^{62}$ RANGEL, Lúcio. A Lapa e a música popular. In: DAMATA, Gasparino. Antologia da Lapa. $3^{\text {a }}$ edição. Rio de Janeiro: Desiderata, 2007. p.82

${ }^{63}$ Ibid
} 
comerciantes e empresários reavivam o samba para a recuperação econômica do bairro, visto que cada vez mais jovens buscam esses gênero musical, como visto acima, em um mecanismo de defesa e resgate própria identidade.

A maior parte da música tocada no bairro (cerca de 70\%) é pertencente a esses gêneros musicais supracitados, fato que é um indicativo do interesse dos atores e empresários locais em estabelecer uma identidade, criar um "perfil" para o território. No entanto, embora o circuito samba-choro tenha construído fortes raízes na Lapa, sendo considerado por muitos como o baluarte da reconstrução, a região não se dedica exclusivamente a esse tipo de música. $\mathrm{O}$ bairro se configura como um espaço democrático, onde se tem a circulação de vários estilos musicais. (HERSCHMANN, 2007)

Mais de 100 mil pessoas circulam na área em um final de semana e boa parte deste público está disposta a consumir música nos estabelecimentos comerciais do local. Atraindo comerciantes e empresários já estabelecidos na cidade e que pretendem aproveitar a prosperidade do lugar, botequins como o Informal, o Belmonte; empreendimentos como os do Grupo Matriz - Choperia Brazzoka, CineLapa, Bar da Ladeira; o Lapa 40 graus - sinuca \& Gafieira evidenciam uma transformação veloz e uma complexidade própria da espacialidade capitalista. (OLIVEIRA e SANTOS, 2010:3)

Como podemos ver acima, o que se verifica na Lapa é uma revalorização, da qual fazem parte cadeias de entretenimento. A revitalização desse lugar central da cidade tem sido realizada por meio da evocação de uma tradição boêmia do bairro. Empresários e comerciantes aproveitam-se do imaginário popular construído, do bairro como local de boemia, e hoje alimentado, que atrai cada vez mais jovem para a região. Oliveira e Santos (2010) atentam para o uso instrumental da música nessa promoção da imagem da cidade, convertendo a Lapa numa vitrine para gêneros musicais conectados à identidade da cidade. 


\section{5. \\ CONSIDERAÇÕES FINAIS}

Desde o final dos anos 1990, assiste-se a uma intensa revitalização da Lapa, na cidade do Rio de Janeiro. A valorização cultural do bairro tem ocorrido por meio de investimentos culturais no centro histórico da cidade, e por meio de estratégias de apropriação do espaço material. Por ser um local dotado de simbolismos remete o visitante a um retorno às tradições. "Tradição" tem sido a palavra de ordem dessa revitalização, servindo para reforçar e legitimar práticas atuais.

De acordo com a perspectiva sociológica, a tradição tem o papel de preservar, por meio da repetição, práticas eficazes no passado. Trata-se de valores, costumes e manifestações que são conservados pelo fato de serem considerados valiosos aos olhos da sociedade e que se pretende incutir às novas gerações. É algo que se herda e que faz parte da identidade cultural e social. Ao estudar o mundo contemporâneo, Eric Hobsbawn (1997) passou a utilizar conceito de "tradições inventadas". De acordo com o autor, tal termo inclui tanto as "tradições" realmente inventadas, construídas e formalmente institucionalizadas, quanto as que surgiram de maneira mais difícil de localizar num período limitado e determinado de tempo e que se estabeleceram com enorme rapidez. Segundo Hobsbawn:

Por "tradição inventada" entende-se um conjunto de práticas, normalmente reguladas por regras tácita ou abertamente aceitas; tais práticas, de natureza ritual ou simbólica, visam inculcar certos valores e normas de comportamento através da repetição, o que implica, automaticamente; uma continuidade em relação ao passado. (HOBSBAWN, 1997:9)

É essa continuidade com o passado que se busca construir com a retomada do bairro da Lapa. Hoje a Lapa desponta, sob as sombras do passado. As narrativas sobre a Lapa intelectual e ilustre contribuem para que hoje queira se retornar ao Rio Antigo. O culto ao passado tem sido preponderante para a retomada do bairro, comerciantes, entre outros agentes interessados nessa revitalização, vendem a boemia sob o invólucro de ontem. (BARTOLY, 2010). 
Com esse resgate do passado, da tradição, espera-se reforçar as noções de identidade e memória brasileiras, numa busca incessante por vínculos identitários em uma ligação entre o presente e o passado. Para tal, ancora-se no imaginário construído sobre a Lapa. O resgate da boemia e imprescindível para a retomada do bairro da Lapa.

A boemia buscou construir uma Lapa para si. Os boêmios descrevem duas Lapas, a pecaminosa, responsável em parte pela decadência do bairro, já que por ela medidas restritivas foram impostas e a Lapa descaracterizada e, por conseguinte, abandonada; e a sadia, da qual eles faziam parte, que somente contemplava a "outra" Lapa, não se deixando corromper por ela.

O discurso boêmio apoia-se na moralidade burguesa, o que se constitui um paradoxo, já que muitos autores colocam a boemia na linha frente contra o pensamento burguês. A boemia de 30 era constituída por jovens intelectuais que passavam por ela enquanto não repousavam no casamento e na produtividade econômica da sociedade. A boemia lapiana era o outro lado da centralidade, a boemia não pertencia às margens, sua situação era de passagem. As narrativas dos boêmios sobre a Lapa descrevem o território em sua plenitude, ainda que eles se apressem em afirmar que de muitos aspectos que cercam o bairro, eles não fizeram parte. Os boêmios afirmam que não jogavam, não usavam alcaloides, não frequentavam cabarés, estavam na Lapa, julgavam possuí-la, mas não viviam-na em sua plenitude.

A Lapa sempre foi vista como local do vício e do pecado consentido. Um dos grandes atrativos do bairro eram suas prostitutas, muito descritas nas narrativas memorialísticas dos boêmios. Segundo Kushnir, toda a idéia de uma vida boêmia ali existente era associada às práticas de uma suposta decadência moral, as tentativas de provocar a derrocada física daquele ambiente sobrevoaram algumas vezes esse "território livre". Pela força da caneta, esse espaço do "pecado permitido" foi condenado a desaparecer. As prostitutas foram expulsas levando consigo parte do encanto do bairro.

A Lapa que se busca construir hoje está pautada nessa ideia de boemia, enquanto um divertimento menor para os jovens. Os atuais boêmios da Lapa em muito se assemelham à "boemia sadia" de 30: escolarizados, oriundos dos quadros sociais médios ou superiores, perfeitamente integrados à estrutura produtiva e aos valores dominantes da sociedade. Uma espécie de elite na sociabilidade da vida 
noturna.

A Lapa sempre esteve vinculada à boemia, transgressão, prostituição e malandragem; território do pecado consentido. No entanto, o imaginário que se construiu em torno das figuras femininas, da ideia de transgressão e malandragem, diferentemente do que ocorre com a dita "boemia sadia", não se pretende resgatar. A tradição em que se baseia o renascimento do bairro é em parte inventada.

O samba e o choro têm contribuído para a retomada do bairro. Fala-se em retorno às tradições. Essa é uma tradição inventada. Como já visto acima, esses gêneros musicais não faziam parte da Lapa, mas é pautada neles, juntamente com o resgate de boemia de sadia, que a revitalização tem sido realizada.

Herschmann (2007) define o consumo de choro e samba no bairro, como "resistência cultural", reafirmando uma identidade local/nacional que claramente se opõe ou que se coloca em questão a tensão com a presença, no país, de uma cultura transnacional/globalizada e ao possibilitar o sentimento de engajamento em torno da "defesa da identidade nacional". A Lapa tem valor enquanto terreno fértil, para a circulação de ideias, para formação de identidades e de consciência política. Os projetos implementados na reforma urbana do centro tem como objetivo final a construção de um espaço central para a sociabilidade, principalmente em torno da vida noturna. No entanto, essa retomada do bairro da Lapa atende a interesses de ordem mercadológica. A Lapa tem sido valorizada como "point noturno de diversos grupos sociais" e "como espaço privilegiado daqueles que se disponham a (ou tenham condições de) pagar o preço do entretenimento alçado à categoria cult” (Silveira, 2004: 113). A força imagética do bairro reside hoje em formas de lazer organizadas pelos agentes públicos e privados que tentam garantir as condições de sociabilidade através de projetos urbanos modernos. (SOUZA et al., 2013).

Mas nessa nova Lapa onde estão as prostitutas, moradores antigos, moradores de rua e travestis? Ações, por parte do governo, desejam "limpar" a Lapa, como pudemos ver as com as medidas tomadas pelas operações Lapa Legal e Lapa Presente, retirando-os do bairro. No espaço revitalizado, não há lugar para eles. Quer dizer, eles estão na Lapa, durante o dia. Em geral, os moradores só têm contato com a Lapa do dia. A Lapa da noite, não é para eles. A exceção, de acordo com Bartoly (2010), fica por conta das novas construções imobiliárias, que não são para os moradores que já estavam na Lapa. A "revitalização" não lembrou, 
mesmo tendo participação do Estado, daqueles que já moravam na Lapa. (BARTOLY, 2010). O patrulhamento e policiamento do Lapa Presente, por exemplo só ocorre durante a noite. Sem o glamour da noite, a Lapa é pobre e insegura.

Essa retomada da vida cultural e noturna do bairro é um fenômeno também contemplado por outras grandes cidades ao redor do mundo. Este processo acompanhou um modelo mais geral característico inicialmente das cidades europeias no final dos anos 1970, como uma forma de superação da crise urbana e econômica pela qual atravessavam aqueles países. No final dos anos 1980 esse movimento se ampliou para diversas cidades latino-americanas. Novos usos têm sido dados aos centros históricos. Observa- se uma releitura, uma ressemantização dos lugares.

Tal fenômeno urbano é conhecido como gentrificação e segundo Bidou Zachariasen (2006), se organiza de suas formas: por meio da promoção imobiliária nas áreas centrais, há uma transformação na composição social dos moradores no centro, as camadas populares são substituídas pelas camadas médias assalariadas - temos como exemplo, na Lapa, o Cores da Lapa - e da estratégia de atores individuais atraídos pelo modo de vida e consumo possibilitado pela vida no centro da cidade. Alguns estudiosos do urbanismo e de planejamento urbano criticam a gentrificação devido ao seu caráter excludente e privatizador

As práticas de gentrificação, sublinha Souza (2012), não se referem apenas ao enobrecimento patrimonial e aos empreendimentos econômicos que visam a recuperação do patrimônio. Referem se, sobretudo, a uma relação simbólica de poder, mediante aspectos estéticos arquitetônicos e urbanísticos que representam visualmente valores e visões de mundo de novos grupos sociais que buscam apropriar-se do lugar.

Apesar de provocarem mudanças nas estruturas físicas dos bairros, os projetos de revitalização urbana garantem a integridade das edificações e espaços públicos até então degradados. Podemos observar essa tendência, na Lapa, nos projetos de recuperação das fachadas dos prédios. Preservar esse patrimônio material é fundamental para salvaguardar a memória dos lugares e reforçar, por meio dos símbolos presentes no espaço urbano, a identidade local. No entanto, essa revitalização mascara o rompimento de certas interações sociais preexistentes a ela. 
A Lapa fecha um ciclo apogeu, decadência e reconstrução. Cada etapa desse ciclo foi construída sempre apoiada em um imaginário sobre o bairro. Primeiramente, construiu-se a Montmartre Carioca, os boêmios emprestaram todo um encanto poético ao lugar. Depois, as investidas moralistas objetivavam a destruição do bairro, apoiados em imaginário, construído socialmente, da Lapa como um local de perversão e imoralidades. Hoje, a Lapa desponta apoiada em imaginário de boemia sadia, berço da boemia intelectual carioca. Como a sua existência é um ciclo, corre-se o risco de ele recomeçar. Será que a decadência está reservada à Lapa novamente? A recuperação da Lapa segue em parte o mesmo movimento que levou à sua decadência - a expulsão de segmentos marginalizados, por meio das atuais políticas públicas. Segundo Kushnir (2001), há que se aproximar os espaços e desconstruir a visão de uma cidade sã versus o lupanar, investindo, portanto, no contato e na mistura. Como também, acreditando que não são os mortos que dominam os vivos e, sim, que há uma tradição e uma cultura vinculadas aos processos de criatividade e não de fossilização.

Ainda que apoiada num imaginário, essa revitalização deve levar em consideração as estruturas que existem na Lapa hoje. A cultura, dita popular, que hoje é encenada na Lapa, em nada remete à da maioria da população do Rio de Janeiro, mas, são sim manifestações de uma minoritária elite intelectual que se apropriou dela, engessando-a. A Lapa dividida entre diurna, a Lapa dos moradores e noturna, a empresa da noite, encontra-se em partes.

Para concluir, remeto à ideia de Gaspari, de "apostar no diálogo e na integração das "partes da cidade" e, portanto, discordar da percepção, quase um devaneio lunático, de que a cidade, como um corpo, pode ser partida em pedaços." (KUSHNIR, 2001): “deu- se na Lapa o reencontro das duas cidades que convivem no Rio, a dos pobres e a daqueles que acham que não são pobres. Sempre que essas duas populações se encontram, o Rio floresce. Sempre que elas se separam, a cidade se degrada". No entanto, sabemos de uma coisa: ainda que entre novamente em decadência, a Lapa nunca há de morrer.

E para ilustrar essa não-existência da Lapa, esse não-lugar assumido pelo bairro, que se perpetuou no imaginário popular, Aguinaldo Silva nos presenteia com a sua escrita: 
(...) A Lapa nunca acabará (...) como poderiam destruir uma coisa que só existia dentro de cada um nós? Era com a nossa alma que a refazíamos todas as noites, era com o nosso sumo interior que a preenchíamos, que a transformávamos em território tantas vezes amaldiçoado (...) Se cada um acordava pronto para o grande esforço de logo mais - reconstruir a fantasia chamada Lapa -, como acreditar nas vaguíssimas notícias sobre demolições, derrubadas, sobre o fim daquilo que todas as noites fabricávamos?

A Lapa foi, é e sempre será uma construção que se pauta muito mais no imaginário perpetuado do que nas transformações físicas pelas quais passa. Por isso, nunca morrerá, porque nunca existiu, senão no imaginário, e no esforço diário dos boêmios em refazer esse lugar, essa ilusão, esse "paraíso perdido". 


\section{6. \\ Referências Bibliográficas}

ABREU, M. A. Evolução urbana do Rio de Janeiro. Rio de Janeiro: IPP, 2006.

ALVARENGA, Telma. A Lapa e outras surpresas Bairros esquecidos pela indústria da construção mostram seu valor no mercado. http://veja.abril.com.br/vejarj/290306/p_012.html

ANDRADE, Moacyr. Salve as aquarelas. In. LUSTOSA, Isabel. Lapa do desterro e do desvario - Uma antologia/ vários autores. Rio de Janeiro: Casa da Palavra, 2001.

ANDRADE, Oswald. Serafim Ponte Grande. Obras Completas. 2.ed. MEC, Rio de Janeiro: Civilização Brasileira, 1971.

ANTÔNIO, João. A Lapa acordada para morrer. In. LUSTOSA, Isabel. Lapa do desterro e do desvario - Uma antologia/ vários autores. Rio de Janeiro: Casa da Palavra, 2001.

ARAÚJO, Alberto Filipe; TEIXEIRA, Maria Cecília Sanchez. Gilbert Durand e a pedagogia do imaginário. Letras de Hoje, Porto Alegre, v. 44, n. 4, p. 7-13, out./dez. 2009. Disponível em: http://revistaseletronicas.pucrs.br/fo/ojs/index.php/fale/article/viewFile/6539/4746 Acesso em 12/05/2013

ARAÚJO, Júlia Silveira. O resgate do "samba de raiz" no Rio de Janeiro pós 1990. V Congresso de Estudantes de Pós - graduação em Comunicação. Universidade Federal Fluminense, Niterói. 24 a 26 de outubro de 2012.

ARAÚJO, Júlia Silveira. Uma abordagem midiática do "samba de classe média": Cultura popular e favela como objetos de consumo. VI Congresso de 
Estudantes de Pós - graduação em Comunicação. Universidade do Estado do Rio de Janeiro, Rio de Janeiro. 23 a 25 de outubro de 2013.

ARAÚJO, Vanessa Jorge. Lapa Carioca, Uma (Re)Apropriação do Lugar. Dissertação (Mestrado em Planejamento Urbano e Regional) - Universidade Federal do Rio de Janeiro, Rio de Janeiro, 2009.

BARROS, José D’Assunção. História, imaginário e mentalidades: delineamentos possíveis. Conexão 2007. Conexão - Comunicação e Cultura, UCS, Caxias do Sul, v. 6, n. 11, jan./jun. 2007 - Disponível em: www.ucs.br/etc/revistas/index.php/conexao/article/view/191/182. Acesso em: 12/05/2013.

BARTOLY, Flávio Sampaio. Da Lapa boêmia à Lapa reificada como lugar do espetáculo: Uma análise de dois períodos da história da produção do lugar na cidade do Rio de Janeiro. Anais do XVI Encontro Nacional de Geógrafos Crise, práxis e autonomia: espaços de resistência e de esperanças - Espaço de diálogos e práticas. Porto Alegre, 2010.

BAUDELAIRE, Charles. O pintor da vida moderna In: Poesia e Prosa. Trad. Joana Angélica D' Ávila de Melo e Marcella Martara. Rio de Janeiro: Nova Aguilar, 1995.

BENATTI, Antonio Paulo. O CENTRO E AS MARGENS. Boêmia e prostituição na "capital mundial do café" (Londrina: 1930-1970). Dissertação apresentada à Universidade Federal d 'Paraná. CURITIBA, 1996. ri.uepg.br:8080/riuepg/.../DISSERTAÇÃO_AntonioPauloBenatte.pdf?...1. Acesso em $24 / 06 / 2013$

BENJAMIN, Walter. A Modernidade e os Modernos. 2. ed. Rio de Janeiro: Tempo Brasileiro, 2000.

BERGER, Peter e LUCKMANN, Thomas: “A Construção Social da Realidade: tratado de sociologia do conhecimento". 35. Ed.; trad. Floriano de Souza Fernandes, Petrópolis: Vozes, 2003. 
BERMAN, Marshal. Tudo que é sólido desmancha no ar: A aventura da modernidade. Trad. Carlos Felipe Moisés. São Paulo: Companhia das Letras, 1986.

BIDOU ZACHARIASEN, Catherine. Introdução. De volta à cidade: dos processos de gentrificação às políticas de "revitalização" dos centros urbanos. São Paulo: Annablume, 2006. (pp. 21-54)

BOURDIEU, Pierre. As Regras da arte. São Paulo: Companhia das letras, 1996.

BRANDÃO, Joseane Paiva Macedo. Cultura, Patrimônio e Lazer na Construção Social do Espaço Público no Rio de Janeiro: A "Revitalização" da Lapa. Universidade Federal de Sergipe. Disponível em: http://www.xiconlab.eventos.dype.com.br/resources/anais/3/1308265343_.Acesso em : 22/11/2013-

BULFINCH, Thomas. O livro de ouro da mitologia. Histórias de deuses e heróis. Trad. David Jardim. Rio de Janeiro: Ediouro, 2006.

CASTORIAIDIS, Cornélius. A instituição imaginária da sociedade. Tradução Guy Reynoud. 2.ed. Rio de Janeiro: Paz e Terra, 1982.

CASTRO, I.E. Solidariedade territorial e representação. Novas questões para o pacto federativo nacional. Anais do $6^{\circ}$ Encuentro de Geógrafos e América Latina, realizado en 17 a 21 de Março de 1997 em Buenos Aires - Argentina: Facultad e Filosofía y Letras - UBA, 1997. www.revistaterritorio.com.br/pdf/02_4_castro.pdf Acesso em:15/10/2013

CASTRO, Ruy. Noites da Lapa. In. MARTINS. Luis. Lapa. . $3^{\circ}$ edição. Rio de Janeiro: Editora José Olympio, 2004.

CEMIN, Arneide Bandeira. Entre o cristal e a fumaça: afinal o que é o imaginário? - UNIR Universidade Federal de Rondônia. Revista Eletrônica do 
Centro de Estudos do Imaginário. - Disponível em: www.cei.unir.br/artigo14.html. Acesso em: 12/05/2013

CHALHUB, Júnior. O Imaginário da Cidade como Patrimônio Socioambiental e a Globalização . SHCU -1990 - Seminário da História da Cidade e do urbanismo. Capa $>$ v. 11, n. 5 (2010). Disponível em: www.anpur.org.br > > Acesso em: 12/05/2013

COSTA, Rosalina Maria. Em busca de um espaço perdido - A construção das identidades espaciais do bairro da Lapa na cidade do Rio de Janeiro. Dissertação de mestrado, PPGG - UFRJ, Rio de Janeiro, 1993.

COUTO, Ribeiro. Uma noite de Chuva ou Simão, diletante de ambientes. In. LUSTOSA, Isabel. Lapa do desterro e do desvario - Uma antologia/ vários autores. Rio de Janeiro: Casa da Palavra, 2001.

DAMATA, Gasparino. Antologia da Lapa. $3^{\text {a }}$ edição. Rio de Janeiro: Desiderata, 2007.

DELEUZE, Gilles. Dúvidas sobre o imaginário. Rio de Janeiro: Editora 34, 1992.

DEODATO, Roteiro da Lapa e outros roteiros. Belo Horizonte: Itatiaia, 1960 Doutorado, Escola de Comunicação - Universidade Federal do Rio de Janeiro, 2006. DP\&A, 2005.

DRUMMOND, Carlos. A Lapa vista de longe. In: DAMATA, Gasparino. Antologia da Lapa. $3^{a}$ edição. Rio de Janeiro: Desiderata, 2007.

DUARTE, Cristóvão Fernandes. A Lapa, Abrigo e Refúgio da Cultura Popular Carioca.In: Anais do XIII Encontro Nacional da ANPUR: Planejamento e Gestão do Território, Florianópolis, 25 - 29 de maio de 2009. Florianópolis: Anpur, 2009. 
DURAND, Gilbert. As estruturas antropológicas do imaginário. 3 ed. São Paulo: Martins Fontes, 2002.

FISCHER, Almeida. A Lapa. In: DAMATA, Gasparino. Antologia da Lapa. $3^{\mathrm{a}}$ edição. Rio de Janeiro: Desiderata, 2007.

FONSECA, Angelo Rodrigues de . Criminosos, boémios, prostitutas e outros marginais - O Mundo da Transgressão Social. Disponível em: http://educar.files.wordpress.com/2007/07/boemia.pdf. Acesso em: 22/11/2013

FORTUNA, Perfeito. A Lapa de todos e de cada um. (Entrevista). In: Revista Guia Cultural do Rio de Janeiro. Ano I - No 01 - Abril de 2004. Impresso.

GASPARI, Elio. A linda lição da Lapa. Folha de São Paulo. São Paulo, quartafeira, 10 de abril de 2002. Disponível em: htto://www1.folha.uol.com.br/fsp/brasil/fc1004200223.htm.. Acesso em: $12 / 02 / 2014$.

GÓES, Claudia. O choro na Lapa: comunicação, movimento musical e "revitalização" do Rio Antigo" Revista Os Urbanitas Vol 4, nº5, 2007. Disponível em: <http://www.aguaforte.com/osurbanitas5/Goes2007.html > Acesso: em 20/07/09

GOMES, Renato Cordeiro. Todas as cidades, a cidade: literatura e experiência urbana. Rio de Janeiro : Rocco, 2008.

Nota inédita para o poema $O$ santeiro do Mangue, em Oswald de Andrade. Obra incompleta (Coord.: Jorge Schwartz). Paris: ALLCA XX/Archivos, no prelo. 2002.

GREEN, James N. O Pasquim e Madame Satã, a "rainha" negra da boemia brasileira. TOPOI, v. 4, n. 7, jul.-dez. 2003, pp. 201-221. Disponível em: evistatopoi.org/numeros_anteriores/Topoi\%2007/topoi7a1.pd. Acesso em: 
22/11/2013-

GRUMAN, Marcelo. A Prostituição Judaica no Início do Século XX: desafio à construção de uma identidade étnica positiva no Brasil. CAMPOS - Revista de Antropologia Social. PPGAS-MN-UFRJ Capa > v. 13, n. 1 (2012). Disponível em: ojs.c3sl.ufpr.br/ojs/index.php/campos/article/view/5446 . Acesso em $25 / 05 / 2013$

GUATTARRI, Felix; ROLNIK, Suely. Micropolítica. Cartografias do Desejo.

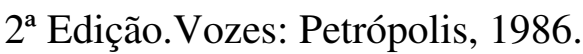

HALL, Stuart. A identidade cultural na pós-modernidade. Rio de Janeiro: DP\&A, 2006.

HARVEY, David. Condição Pós- Moderna - Uma Pesquisa sobre as Origens da Mudança Cultural. Trad. Adail Ubirajara Sobral e Maria Stela Gonçalves. São Paulo: Edições Loyola, 2006.

HERSCHMANN, Micael. Lapa, cidade da música. Desafios e perspectivas para o crescimento do Rio de Janeiro e da indústria da música independente nacional.Rio de Janeiro: Mauad X, 2007

HOBSBAWN, Eric; RANGER, Terence (orgs). A invenção das Tradições. Rio de Janeiro: Paz e Terra, 1997. p.9-23

IRAJÁ, Hernani. Adeus! Lapa. 1. ed., Rio de Janeiro: Record, 1967.

IRIAS, Frederico Duarte. A renovação urbana da Lapa, Rio de Janeiro: Um território de conflito? Dissertação apresentada ao Curso de Mestrado do Programa de Pós-Graduação em Planejamento Urbano e Regional da Universidade Federal do Rio de Janeiro - UFRJ. Rio de Janeiro, 2007

ISER, Wolfgang. Os atos de fingir ou que é fictício no texto ficcional. In: 
KEHL, Maria Rita. Boêmia e malandragem: a preguiça na cadência do samba. Elogio à preguiça. Disponível em: http://elogioapreguica.com.br/?page_id=51. Acesso em: 24/08/2013

KUSHNIR, Beatriz. "A Lapa e os filhos da revolução boêmia”. In: Lapa do desterro e do desvario - uma antologia. LUSTOSA, Isabel. Org. Rio de Janeiro, Casa da Palavra, 2001.

LE GOFF, Jacques. História e memória. Campinas: Editora da Unicamp, 1996.

LEI N. 506 DE 17 DE JANEIRO DE 1984 . Cria a Zona Especial do Corredor Cultural, de proteção paisagística e ambiental do Centro da Cidade. Disponível em:http://www0.rio.rj.gov.br/patrimonio/pastas/legislacao/centro_lei506_84_corr edor_cultural.pdf - Acesso em: 20 de agosto de 2013.

LEI N ${ }^{\circ}$ 5.407, DE 17 DE MAIO DE 2012. Cria o Bairro da Lapa, pela subdivisão do Bairro do Centro, área da AP 1, II Região Administrativa. Disponível em: http://mail.camara.rj.gov.br/APL/Legislativos/contlei.nsf/7cb7d306c2b748cb0325 796000610ad8/ee3fcc69d06e73bd03257a02004f4969?OpenDocument. Acesso em:02/10/2013

LIMA, Evelyn F.W. Corredor Cultural do Rio de Janeiro: Uma Visão Teórica Sobre as Práticas da Preservação do Patrimônio Cultural. Fórum Patrimônio: amb. Constr. E patr. Sust., Belo horizonte,v.1,n.1,set./dez. 2007. Disponível em: http://www.forumpatrimonio.com.br/material/pdfs/45de5243ec916734b18d.pdf. Acesso em: 12/10/2012.

LIMA, Luiz Costa (org.) Teoria da literatura em sua fontes. Vol 2. 3. Ed. RJ: Civilização Brasileira, 2002.

LUSTOSA, Isabel. Lapa do desterro e do desvario - Uma antologia/ vários autores. Rio de Janeiro: Casa da Palavra, 2001. 
MACEDO, Mirela Arcangelo da Motta. A concepção do projeto corredor cultural do Rio de Janeiro: a participação de técnicos e intelectuais no processo de planejamento urbano. Escola de Engenharia de São Carlos - USP. Disponível em: http://www.anpur.org.br/revista/rbeur/index.php/shcu/article/download/1053/1028 Acesso em: 24/08/2013

MAFESSOLI, Michel . O imaginário é uma realidade - Revista FAMECOS • Porto Alegre - $\mathrm{n}^{\circ} 15$ - agosto 2001 - quadrimestral. Disponível em: 200.144.189.42/ojs/index.php/famecos/article/viewFile/285/217. Acesso em $12 / 05 / 2013$

MAIA, Doralice Sátyro; GUTIERRES, Henrique Elias Pessoa; SOARES, Maria Simone Moraes. A iluminação pública da cidade da Parahyba: século XIX e início do século XX. Fênix - Revista de História e Estudos Culturais. Abril/ Maio/ Junho de 2009 Vol. 6 Ano VI no 2. ISSN: 1807-6971. Disponível em: <www.revistafenix.pro.br.>. Acesso em: 15 jun. 2010

MARTINS, Luís. Noturno da Lapa. $2^{a}$ Ed. São Paulo: Vertente, 1979.

MARTINS. Luis. Lapa. . $3^{\circ}$ edição. Rio de Janeiro: Editora José Olympio, 2004a.

MENEZES, Lená Medeiros de. Os estrangeiros e o comércio do prazer nas ruas do Rio (1890-1930). Rio de Janeiro: Arquivo Nacional, 1992

NORA, Pierre. Entre história e memória: a problemática dos lugares. Revista Projeto História. São Paulo, v. 10, p. 7-28, 1993. Revista do Programa de Estudos Pós-Graduados em História e do Departamento de História da PUC-SP (Pontifícia Universidade Católica de São Paulo).

OLIVEIRA, Anita Loureiro de.; SANTOS, Patricia Daflon dos. Música e imaginários na produção da cidade: a vitalidade complexa da Lapa carioca Scripta Nova - Revista electrónica de geografía y ciencias sociales 
Universidad de Barcelona. ISSN: 1138-9788. Depósito Legal: B. 21.741-98 Vol. XIV, núm. 331 (95), 1 de agosto de 2010

OLIVEIRA, Franklin de. Ler Coelho Neto. In: COELHO NETTO, Henrique Maximiniano. A conquista. Rio de Janeiro: Civilização Brasileira, 1985, pp. VXVI.

PECHMAN, Robert M. \& RIBEIRO, Luiz. C. Q. A crise de moradias no Rio de Janeiro: Contexto histórico. In: O que é questão da moradia. São Paulo: Brasiliense, 2008.

PEREIRA, Leonardo. A. M. Literatura e história social: a geração boêmia no Rio de Janeiro do fim do Império. História Social, Campinas - SP, v. 1, n. 1, p. 29-64, 1994.

PEREZ, Léa Freitas. Notas Reflexivas sobre a modernidade e a cidade. In: NASCIMENTO, Mara Regina do; TORRESINI, Elizabeth W.R. (Org.). Modernidade e Urbanização no Brasil. Porto Alegre: EDIPUCRS, 1998. 170 p. (Coleção História, 24).

Plano de marketing do Pólo Novo Rio Antigo, 2006-2007: 22 http://www.novorioantigo.com.br/img/noticias/pdfs/onde-o-carioca-se-diverte.pdf

PLANO URBANÍSTICO - Rio de Janeiro: Biblioteca: Arquivo Geral da Cidade do Rio de Janeiro - AGCRJ- Cidade Objeto: Rio de Janeiro - Rio de Janeiro. Disponível em: http://www.urbanismobr.org/bd/documentos.php?id=2714. Acesso em: 24/10/2013

POLLAK, Michael. Memória, esquecimento, silêncio. Estudos Históricos, Rio de Janeiro, vol.2, nº 3, 1989.

RANGEL, Lúcio. A Lapa e a música popular. In: DAMATA, Gasparino. Antologia da Lapa. $3^{\text {a }}$ edição. Rio de Janeiro: Desiderata, 2007. 
REQUIÃO Luciana. O trabalho produtivo do músico nas casas de shows da Lapa:um estudo de caso. Revista Trabalho necessário. Issn:1808-799x. ano 7 número 8- 2009.

REQUIÃO, Luciana. Eis aí a Lapa: processos e relações de trabalho do músico nas casas de show da Lapa. São Paulo: Annablume, 2010.

RIBEIRO, Miguel Angelo Campos; MATTOS, Rogério Botelho de. Territórios da prostituição nos espaços públicos da área central do Rio de Janeiro Revista Território, 1(1), $1996 . \quad$ Disponível em: www.revistaterritorio.com.br/pdf/01_6_ribeiro_\%20mattos.pdf - Acesso em: $12 / 05 / 2013$

RICOEUR, Paul. O percurso do reconhecimento. Trad. Nicolás Nyimi Campanário. Edições Loyola: São Paulo, 2006.

Rio de Janeiro, Rio de Janeiro, 2009.

RIO, João do. A alma encantadora das ruas. Organização de Raul Antelo. São Paulo: Companhia das Letras, 1997.

ROCHA, Gilmar. O Rei da Lapa: Madame Satã e a malandragem carioca: uma história de violência no Rio de Janeiro dos anos 30-50. Rio de Janeiro: 7Letras, 2004.

RODRIGUES, Nilton Júnior, Vidraças do Ouvidor: a Rua do Ouvidor na formação do capitalismo carioca. Revista Espaço Acadêmico - N ${ }^{\circ} 65$ Outubro/2006. Ano VI. Disponível em: http://www.espacoacademico.com.br/065/65rodrigues.htm. Acesso 07/07/2010

RODRIGUES, Marlene Teixeira. Polícia e prostituição feminina em Brasília um estudo de caso. 2003. 369 f. Tese (Doutorado em Sociologia)-Universidade de Brasília, Brasília, 2003. http://repositorio.unb.br/handle/10482/1585. Acesso em:14/12/2013 
SANTOS, Ana Cristina. Jorge Luis Borges: Releituras de uma cidade. In: GUBERMAN, Mariluci; PEREIRA, Diana Araùjo (organizadoras.). Provocações da cidade - Rio de Janeiro : M. Guberman: D. Araujo Pereira, 2009

SEIGEL, Jerrold. Paris boêmia: cultura, política e os limites da vida burguesa 1830-1930. Porto Alegre: L\&PM, 1992.

SERBENA, Carlos Augusto. Imaginário, ideologia e representação social. Cadernos de pesquisa interdisciplinar em Ciências Humanas. № 52 - Dezembro de $2003 \quad-\quad$ ISSN 1678-7730. Disponível em: https://periodicos.ufsc.br/index.php/cadernosdepesquisa/article/view/1944. Acesso em 12/05/2013

SEVCENKO, Nicolau. Literatura como Missão: tensões sociais e criação cultural na Primeira República. 2ed. São Paulo: Companhia das Letras, 2003.

SILVA, Aguinaldo. Lábios que beijei. São Paulo: Siciliano, 1992.

SILVA JÚNIOR, Otoniel Fernandes da. Por uma Geografia do Imaginário: percorrendo o labiríntico mundo. Revista Eletrônica do Centro de Estudos do Imaginário - UNIR . Universidade Federal de Rondônia. Julho - Setembro de 2001. Disponível em: www.cei.unir.br/artigo31.html 1/9. Acesso em: 12/05/2013

SILVEIRA, C. O entrelaçamento urbano-cultural: centralidade e memória na cidade do Rio de Janeiro. Rio de Janeiro: UFRJ, 2004.

SOJA, Edward W. Geografias pós-modernas: a reafirmação do espaço na teoria social crítica. Trad. Da 2. Ed. Inglesa Vera Ribeiro; revisão técnica de Bertha Becker, Lia Machado. Rio de Janeiro: Jorge Zahar Ed., 1993.

SOUZA, Marcelo José Lopes. O território: sobre espaço e poder, autonomia e desenvolvimento. In: Geografia conceitos e temas, 2012. 
TROTTA, Felipe da Costa. Samba e mercado de música nos anos 1990. Tese de Doutorado apresentada à Escola de Comunicação da Universidade Federal do Rio de Janeiro (ECO-UFRJ). Rio e Janeiro, 2006. 259 p.

Produção Cultural e Qualidade Estética: o caso da música popular. Intercom -Sociedade Brasileira de Estudos Interdisciplinares da Comunicação. IX Congresso Brasileiro de Ciências da Comunicação da Região Nordeste-Salvador-BA, 2007

VELASQUES, Muza Clara Chaves. A Lapa boêmia: Um estudo da identidade carioca. Disertação- Departamento de história - UFF. Niterói, 1994. Disponível em : www.historia.uff.br/stricto/td/732.p_df. Acesso em 13/09/2013

VILAS BOAS, Violeta Pires. A Lapa como estudo de caso as memórias e suas permanências na cidade: PROURB - Programa de Pós Graduação em Urbanismo - $\quad$ UFRJ em: http://www.ppgau.ufba.br/urbicentros/2012/ST132.pdf, Acesso em: 22/11/2013-

ZANON, Maria Cecilia. A sociedade carioca da belle époque nas páginas do fon-fon! Unesp - FCLAs - CEDAP, v.4, n.2, p. 217-235, jun. 2009. ISSN 1808-1967. Disponível em: $<$ pem.assis.unesp.br/index.php/pem/article/download/178/510>. Acesso em: $05 / 12 / 2012$ 


\section{Anexo I}

Principais pontos de lazer e entretenimento no bairro da Lapa - Disponíveis em:

http://www.nossadica.com/lapa_dancar.php

http://www.feriasbrasil.com.br/rj/riodejaneiro/noitenalapa.cfm

Asa Branca - Ponto de referência da tradição musical nordestina no Rio. Na pista predomina o forró; no cardápio, as especialidades regionais.

Cabaret Casanova - Referência da noite drag do Rio, palco das famosas Laura de Vison. e Meime dos Olhos. A noite mais movimentada é a sextafeira. Shows musicais nos domingos.

\section{AV. MEM DE SÁ}

Café Cultural Sacrilégio - Já era um ativo centro de produção cultural quando abriu o café, com cardápio de petiscos, carpaccios e sanduíches. Música ao vivo no estilo samba e choro, e homenagens mensais a grandes nomes da MPB. Exposições e workshops sobre o tema.

Café Musical Carioca Da Gema - Vários ambientes em um casarão com música ao vivo samba e choro e um cardápio de forno e fogão. 
Carlito's Up - Sobreloja Casarão de três andares num ponto estratégico da Lapa, com intensa programação de festas regadas a samba, funk e hip-hop.

Casa Brasil Mestiço - Ponto de referência da música popular, do Rio e do Brasil, de todas as etnias e regiões: samba, choro, forró, maracatu, afoxé, coco, jongo, ciranda. Serviço completo de bar. Procure pelo calendário de oficinas e concursos.

AV. MEM DE SÁ

Cine Lapa - Espaço multiuso em dois pavimentos: palco, pistas de dança, bares e uma sala de cinema digital com 40 lugares. Nas antigas cadeiras do Cine Paissandu, aproveite a programação do cineclube. Eventos variados, desde desfiles de moda até festas de música eletrônica e hip-hop.

Estrela da Lapa - Lindo casarão com decoração art-nouveau, administrado pela equipe do antigo, Mistura Fina. Boa música, cardápio para refeições ligeiras e opção para festas fechadas de até 400 pessoas.

Mofo - Pé-limpo pequeno e simpático, destaca-se pelo pastel de bacalhau e a "tábua de caipirinhas" (seis copinhos com frutas variadas) 
Sal y Pimenta - Em dois andares, bar com música ao vivo, shows, performances e go-go's. Na boate anexa, Djs até as altas da madrugada. Muito procurada pelo público gay.

Clube Dos Democráticos - Antiga sociedade social recreativa com 140 anos de história, tem um público fiel que enche o salão de quarta a sábado. Aos domingos, a partir das 20h, dançarinos contratados pela casa não deixam ninguém ficar RUA DO RIACHUELO parado .

Lapa 40 Graus - Recém-inaugurada, a casa do dançarino e coreógrafo Carlinhos de Jesus, tem como especialidades a sinuca e a gafieira, além de shows com os maiores nomes da música brasileira.

RUAS DOS ARCOS

Circo Voador - Herdeiro de uma geração contestadora dos anos 80, berço do Rock dispõe hoje de uma estrutura de palco e platéia de ótima qualidade. Shows e festas nos mais variados estilos de música popular dividem o espaço com projetos de educação e inclusão social. 
Fundição Progresso - Em seus galpões, abriga variada programação de shows, feiras, eventos, festas, cursos. Oferece regularmente diversos cursos de capacitação e qualificação profissional. Recentemente inaugurou uma grande choperia, a Parada da Lapa.

Comuna do Semente - No pé dos Arcos da Lapa, JOAQUIM SILVA o antigo Bar Semente fez história na MPB. Reaberto pela sua própria comunidade, combina música carioca de raiz e um ambiente de botequim para 80 pessoas.

\section{Mistura Carioca Bar E Restaurante - A}

RUA GOMES FREIRE programação musical: samba e ritmos cariocas em geral. Decoração cuidadosa, no estilo rio antigo, e uma ótima pista de dança. 